\title{
Locked In? The Enforceability of Covenants Not to Compete and the Careers of High-Tech Workers
}

by

\section{Natarajan Balasubramanian \\ Syracuse University}

\author{
Jin Woo Chang \\ University of Michigan
}

Mariko Sakakibara

University of California, Los Angeles

\author{
Jagadeesh Sivadasan \\ University of Michigan \\ Evan Starr \\ University of Maryland
}

CES 17-09

January, 2017

The research program of the Center for Economic Studies (CES) produces a wide range of economic analyses to improve the statistical programs of the U.S. Census Bureau. Many of these analyses take the form of CES research papers. The papers have not undergone the review accorded Census Bureau publications and no endorsement should be inferred. Any opinions and conclusions expressed herein are those of the author(s) and do not necessarily represent the views of the U.S. Census Bureau. All results have been reviewed to ensure that no confidential information is disclosed. Republication in whole or part must be cleared with the authors.

To obtain information about the series, see www.census.gov/ces or contact J. David Brown, Editor, Discussion Papers, U.S. Census Bureau, Center for Economic Studies 5K034A, 4600 Silver Hill Road, Washington, DC 20233, CES.Papers.List@census.gov. To subscribe to the series, please click here. 


\begin{abstract}
We examine how the enforceability of covenants not to compete (CNCs) affects employee mobility and wages of high-tech workers. We expect CNC enforceability to lengthen job spells and constrain mobility, but its impact on wages is ambiguous. Using a matched employeremployee dataset covering the universe of jobs in thirty U.S states, we find that higher CNC enforceability is associated with longer job spells (fewer jobs over time), and a greater chance of leaving the state for technology workers. Consistent with a "lock-in" effect of CNCs, we find persistent wage-suppressing effects that last throughout a worker's job and employment history.
\end{abstract}

\footnotetext{
${ }^{*}$ U.S. Census Bureau Disclaimer: Research results in this paper are those of the authors, and do not necessarily represent the views of the U.S. Census Bureau. The results presented here have been screened to ensure that no confidential data is revealed. We thank Clint Carter and others at CES for all their assistance. This research uses data from the Census Bureau's Longitudinal Employer Household Dynamics Program, which was partially supported by the following National Science Foundation Grants SES-9978093, SES-0339191, and ITR-0427889; National Institute on Aging Grant AG018854; and grants from the Alfred P. Sloan Foundation.
} 


\section{Introduction}

Human capital accumulation by workers is a key source of productivity growth, both at the aggregate (e.g., Romer 1989) as well as at the firm-level (e.g., Bartel 1994). Workers accumulate human capital at their jobs through their own effort, and through training and related investments made by their employers. Because skills are often not entirely firm-specific (Becker 1962; Lazear 2009), when employees can quit at will, employers facing the possibility of a trained worker leaving their employment might be discouraged from making investments in the worker's human capital in the first place (Rajan and Zingales 2001). Employers might be especially discouraged from providing employees with valuable training or information if they are concerned that such investments will be used directly against them in case the employee leaves for a competitor.

One of the policy measures to restore the incentive to make these investments is to allow employers to restrict their workers' freedom to move to other firms through covenants not to compete (CNCs) (Callahan 1985; Sterk 1993), which prohibit employees from either joining competitors or starting a competing firm for a specified amount of time (typically between six months and two years (Gilson 1999)) and in a specified geographic region (Rubin and Shedd, 1981; Posner, Triantis, and Triantis 2004). However, doing so has the potential to reduce the overall mobility of workers across firms.

Further, it has been argued that reducing barriers to worker mobility has a number of potential efficiency benefits from improved match quality and increased entrepreneurship, and spillover benefits from knowledge sharing (Gilson 1999). From an efficiency point of view, a priori, it is unclear if these potential welfare gains from the freedom to move are greater than the potential welfare gains from promoting firm investments in human capital through enforcement 
of (mutually agreed-upon) contractual prohibitions on within-industry mobility. Not surprisingly, states have taken vastly different enforcement approaches, with some states banning CNCs outright and others enforcing them even when the employee is fired. In fact, CNC enforceability is a topic of ongoing, vigorous debate in state legislatures; eleven states have proposed CNC reform laws in the past year. ${ }^{1}$ Indeed, over the past few years, CNCs have also become a focus of attention for policymakers concerned about wage stagnation (Biden 2016), the decline in economic dynamism (Davis and Haltiwanger 2014), and spurring innovation (Zillman 2015).

In this paper, we contribute to the understanding of real-world effects of CNC enforceability on workers using quarterly employment records for the universe of employees with initial earnings more than \$35,000 (2008 dollars) in thirty U.S. states. Specifically, we examine how the variability in CNC enforceability is related to the rate and direction of worker mobility, and the time path of wages both within-jobs and across a worker's career. ${ }^{2}$

Interestingly, like the theoretical ambiguity in the overall welfare benefits of CNC enforceability, it is not theoretically clear that the freedom to move unambiguously benefits individual workers. Though both pro- and anti-enforcement arguments generally generate the same predictions with regard to the relationship between CNC enforceability and mobilityworkers stay longer and are redirected away from competitors - they differ in their predictions

\footnotetext{
${ }^{1}$ See https://faircompetitionlaw.com/the-changing-landscape-of-trade-secrets-laws-andnoncompete-laws/.

2 “Enforcement” refers to the act of enforcing a CNC by a firm or a court; “enforceability” refers to whether a CNC can withstand scrutiny in court.
} 
with regards to the levels and time path of wages both within jobs and over a worker's career. ${ }^{3}$ As pro-enforcement advocates would argue, enforcing solves a holdup problem, providing firms with incentives to invest in the development of highly valuable information that would otherwise be at risk of expropriation (Rubin and Shedd 1981). ${ }^{4}$ Then, not enforcing CNCs may reduce such investments, eventually decreasing worker productivity and potentially worker wages as well. Indeed, Lavetti, Simon and White (2014) find wages to be higher among physicians who sign CNCs because such physicians tend to have a larger client base. In contrast, anti-enforcement advocates would argue that inherent inequities in bargaining power, such as the firm's ability to delay introducing the CNC until after the worker has accepted the job, make it unlikely that workers will be able to properly negotiate for the mobility they give up (Arnow-Richman 2001, 2006), which means they could be "locked in" by CNC enforcement in a low mobility-low wage equilibrium, both at the outset and throughout the job. ${ }^{5}$

${ }^{3}$ Under some conditions, low enforcement may curtail mobility (see model in the Theory Appendix). In particular, if human capital is firm-specific, and if workers invest significantly more in skills when they are less locked in, then in equilibrium, we may see higher levels of human capital and lower job-switching rates in low-enforceability regimes.

${ }^{4}$ There are also benefits from other possible concerns, such as the relationship between CNC enforceability and collusion (Mukherjee and Vasconcelos 2012) and appropriation from new entrants (Posner, Triantis, and Triantis 2004).

${ }^{5}$ Another concern highlighted by these scholars is that increased knowledge flows via worker mobility actually result in more innovation through the recombination of knowledge than when workers are restricted from leaving, as suggested by California's ban on CNCs and the growth of 
We test these contrasting hypotheses using data on the length of job spells, industry- and state-switching behavior, and the time path of wages within a job and across the employee's career using rich employer-employee matched data from the U.S. Census Bureau. We utilize a pseudo difference-in-differences methodology by examining across-state differences in CNC enforceability effects on technology workers (“tech workers”) relative to the effects on nontechnology workers (“non-tech workers”). This approach, which addresses the limitation that variation in CNC enforceability is cross-sectional, rests on our presumption that workers in technology sectors are more likely to embody intellectual capital (e.g., as argued in Marx 2011), so that firms have a stronger incentive to utilize CNCs as a means for protecting intellectual property in technology sectors relative to others. Consistent with this presumption, Starr, Bishara, and Prescott (2016) document higher observed incidence of CNCs for tech workers, and a large literature in law and economics has focused on the effect of CNC enforceability on hightechnology workers (see review in Arnow-Richman 2001). ${ }^{6}$

This pseudo difference-in-differences approach allows us to include state fixed effects, which controls for potential unobserved state level variables (so long as they impact mobility and wages in a similar way across sectors). Further, the richness of our data allows us to include

Silicon Valley (Hyde 2003; Fallick, Fleischman, and Rebitzer 2006; Lobel 2013; Gilson 1999; Samila and Sorenson 2011).

${ }^{6}$ To the extent that we find null effects, this could be because CNCs are equally strongly used in non-tech sectors, in which case our estimates may be biased towards zero. Another reason for our focus on technology workers is that mobility of these workers has been argued to be important sources of knowledge spillovers and a potential source of agglomeration economies (e.g., Gilson 1999, Fallick, Fleischman and Rebitzer 2006). 
interacted "industry-job starting year-firm size-starting wage decile-starting age-sex" fixed effects, so that we compare workers within the same industry, cohort, age, and gender with similar initial wages and employed in similar sized firms, effectively controlling for a number of potential omitted variables that could be correlated (e.g., due to selection on correlated state-level variables by firms or individuals) with CNC enforceability. ${ }^{7}$ This allows us to control for many other determinants of mobility in a fine-grained, non-parametric way that past studies have not been able to. More broadly, by using large-scale, high-frequency data that covers the universe of tech workers in thirty states and by making the link between CNC enforceability and mobility explicit, our results on the length of job spells, increased propensity for cross-state mobility, and reduced within-industry mobility corroborate and significantly generalize the findings of Fallick, Fleischman, and Rebitzer (2006) for tech workers. Our study also significantly generalizes the influential results on the mobility effects of CNC enforceability found in Marx, Strumsky, and Fleming (2009) and Marx, Singh, and Fleming (2015) for patent holders, and Garmaise (2011) for executives.

We find that a one-standard-deviation increase in CNC enforceability increases the length of job-spells for workers in technology industries ("tech jobs") by at least 1.5\%, compared with the length of job-spells for workers in non-technology industries ("non-tech jobs"). Based on

\footnotetext{
${ }^{7}$ For instance, younger workers may be more likely to be in low-CNC jurisdictions (say because other amenities are correlated with low CNC—e.g., good weather in California), so that unconditional differences in mobility across enforceability jurisdictions may reflect differences in age-related mobility differences, rather than true differences induced by enforceability. Our fixed effects are able to non-parametrically condition out this and any such compositional differences to examine differences with a very closely matched set of workers.
} 
this, a technology worker in the highest enforceability state (Florida) would have a 7.5\% longer average length of tech job spells relative to technology workers of the same gender, starting cohort, and age group, in similar sized firms, with similar starting wages employed in the same industry in the lowest enforceability state (California), compared with the differences for a control group of non-tech workers. Our data also allows us to examine the effect of CNC enforceability on mobility over the job spell; the impact of CNC enforceability on the probability of a job spell exceeding a given spell length is initially low, but large, statistically significant, and monotonically increasing in job spell lengths from two to six years, and flat thereafter. This is suggestive of an increase of tech worker value to the firm (making such workers more targeted for mobility restriction) over the job-spells from years two to six, and flattening of worker value thereafter.

We also find that CNC enforceability is related to the type and direction of worker movement in expected ways. In particular, we find that individuals whose first jobs are in the technology sector in higher enforceability states have fewer jobs within their first eight years but are more likely to move across states. Due to human capital investment decisions or location choice by firms, it could be expected that tech workers in high-enforceability states have more industry-specific skills. Consistent with this expectation, we find that individuals starting work in the tech sector in high-enforceability states are also less likely to switch industries, and more likely to move across states without switching industries. To our knowledge, this is the first study to document these interesting empirical regularities.

Beyond significantly generalizing prior results on mobility, the major contribution of this paper is in the treatment of wages. In contrast to existing work, which either examines crosssectional differences in wages (Starr 2016; Starr, Ganco, Campbell 2016), limited to executive 
compensation (Garmaise 2011) or has no data on wages (Marx, Strumsky, and Fleming 2009;

Marx, Singh, and Fleming 2015), we track the time path of wages across the job spell and across the worker's career.

Compared with their peers in low-enforceability states, we find no evidence that the reduced mobility of tech workers in high-enforceability states is offset by higher wage levels. In contrast, consistent with reduced bargaining power in high CNC regimes (as argued by ArnowRichman 2001, 2006), we find that tech workers, conditional on their initial wage, earn lower wages (between $-0.5 \%$ and $-0.7 \%$ for a one-standard-deviation increase in CNC enforceability) throughout their job spell in higher enforceability states. Our results show that at every phase of job tenure, conditional on their initial wage at a firm, tech workers in high-enforceability states earn less than their counterparts in lower enforceability states. In fact, we find that starting a job in a high-enforceability state results in persistently lower wages over the next eight years of the worker's career. Together, our results strongly suggest that CNC enforceability is associated with a "job lock" similar to that discussed in Gruber and Madrian (1994) and reduced bargaining power for the average technical worker (as discussed in Arnow-Richman 2001, 2006).

These baseline findings are robust to analyses using different econometric approaches and to checks using a variety of sub-samples and controls. Even within the tech sector, we expect workers with higher start-of-job-spell wages to have greater intellectual capital and hence be more closely targeted for CNC enforcement by firms, which affords a pseudo triple-difference approach to detecting effects of CNC enforceability. We tested and found a significant pseudo triple-difference effect in the expected direction; that is, higher initial-wage workers in tech sectors have significantly lower mobility and lower wages relative to lower initial-wage tech 
workers in high-CNC-enforceability states, and that this effect is larger relative to similar differences for non-tech workers.

We now turn to a theoretical discussion of how enforceability relates to mobility and worker earnings.

\section{Mobility and Wage Effects of CNC Enforceability}

We use a simple model of mobility and wage determination to understand how CNC enforceability affects the length of job spells and the pattern of wages. We briefly describe the model and underlying intuition here, leaving the details to the Theory Appendix. In our model, the economic value of a worker-firm relationship is given by $\theta$, which reflects the worker's human capital relevant to the firm. The worker searches for opportunities outside the firm, and receives a single offer with wage $\mathrm{W}_{0}$, from a uniform distribution $[0,1+\mu]$. If the outside wage is greater than $\theta$, the worker leaves. Otherwise, the worker negotiates with the firm and obtains a wage $\alpha \theta+(1-\alpha) \mathrm{W}_{0}$, where $\alpha$ is a parameter that reflects the bargaining of the worker. Thus, in this model, worker mobility is determined by the probability of getting an offer above $\theta$, which is determined by where $\theta$ is relative to the upper bound of outside offers $1+\mu$. Average wage is a linear combination of outside wage offers and wages within the firm, conditional on staying.

Enforceable CNCs drive a legal wedge between a departing employee and competing firms, and reduce the range of wage offers received by a worker. ${ }^{8}$ Therefore, increasing CNCs will decrease $\mu$. In addition, enforceability also reduces the bargaining power of a worker within

\footnotetext{
${ }^{8}$ This can be thought of as a simplification of a longer process, where enforceability reduces the potential number of outside offers, which in turn reduces the maximum of those wage offers (for many common distributions of wage offers).
} 
the firm, which affects the share of economic surplus that goes to the worker. That is, increasing enforceability decreases $\alpha$. We refer to this as the "lock-in" effect of enforceability.

When $\theta$ is exogenously determined (that is, individual or firm investments in human capital do not affect $\theta$ ), increasing enforceability does not affect $\theta$, but the maximum possible wage offer, $1+\mu$, decreases. This decreases the probability of exit, thus decreasing worker mobility. Furthermore, because $\alpha$ decreases, average wages also decrease.

However, when $\theta$ is affected by the level of investments made by the firm or worker, the effects are not uniformly unambiguous. Increasing CNC enforceability increases the firm's investment and decreases the worker's investments in human capital. In the case where human capital responds only to firm investment, higher CNC enforceability increases the probability that the worker stays but the effect on wages is ambiguous. This is because higher CNC enforceability increases the firm's investment in $\theta$, which increases the threshold wage for the worker to leave. Since the upper bound of outside offers $(1+\mu)$ falls, the probability of leaving (and worker mobility) declines unambiguously. If higher enforceability does not affect the bargaining power significantly, then the increased human capital from higher firm investments implies higher wages for workers. However, if higher enforceability significantly reduces workers' bargaining power, their wages may decline. This would be consistent with workers being “locked in.”

In the case where human capital responds only to individual investment, both the mobility and wage effects of increasing enforceability are ambiguous. $\theta$ decreases due to decreased individual investment, but so does the upper bound of outside offers. Wages within the firm, conditional on staying, unambiguously decrease due to decreased worker bargaining power 
and decreased worker investment, but average wage levels may not decrease if the probability of leaving and accepting an outside wage offer increases.

This simple framework illustrates that, ultimately, whether CNC enforceability decreases worker mobility and wages or not is an empirical question.

\section{Data}

\subsection{Sample Construction}

We construct a job-level and a worker-level repeated cross-sectional dataset using the Longitudinal Employer-Household Dynamics (LEHD) database at the U.S. Census Bureau. The LEHD is a composite linked employer-employee dataset comprising multiple state-level databases. There are two advantages to using the LEHD for this study. First, the LEHD provides employment history data for individual workers over a long horizon for a full spectrum of industries in the U.S. economy across a large number of states that vary in CNC enforceability levels. Second, the quarterly administrative data on all firms provides a clear measure of job transfer, mobility, and wage at a high-frequency level, largely free from selection issues that may arise in studies that use patenting or listed firm executive employment data.

Linked employer-employee records of employment history are available for thirty states at the worker-firm-year-quarter level in the Employment History File (EHF) within the LEHD. ${ }^{9}$ From the employment history of each worker, we identify jobs at each of the firms where the worker worked (i.e., when there is a change in the firm identifier in the worker's employment

\footnotetext{
${ }^{9}$ The thirty states are Arkansas, California, Colorado, Florida, Georgia, Hawaii, Iowa, Idaho, Illinois, Indiana, Louisiana, Maryland, Maine, Montana, North Carolina, New Jersey, New Mexico, Nevada, Oklahoma, Oregon, Rhode Island, South Carolina, Tennessee, Texas, Utah, Virginia, Vermont, Washington, Wisconsin, and West Virginia.
} 
history, we identify that as a job change). Because the firm identifiers of the EHF are within-state identifiers, we use the national-level firm identifier available in the Business Register Bridge (BRB) for defining the job. This ensures we do not wrongly capture within-firm, inter-state, or intra-state transfers as worker movements out of a firm. Because the link to the BRB is available only from 1991, our dataset for analysis covers the years 1991-2008.

We keep left-censored workers, but drop any left-censored jobs from our dataset because not only we do not know the lengths of the latent spells for these jobs (and we can avoid the bias from stock sampling by dropping these jobs), but also we do not know the characteristics of these jobs at the beginning of the spell, which we use to construct our job-level fixed effects described below. To mitigate concerns with right censoring for the mobility analysis, we restrict our sample to the jobs whose spell started in 2000 or earlier for the analysis on the length of job spells. ${ }^{10}$ We also drop workers whose first-year annual income in the LEHD is less than $\$ 35,000$ in 2008 dollars, as these workers are not likely to have jobs that are knowledge intensive, and therefore are less likely to be affected by CNC enforceability (Starr, Bishara, and Prescott 2016). Secondary jobs (defined by the share of that job's earnings to the worker's total earnings) whose spell is continuing in parallel to another job for the same worker are also dropped.

Finally, we obtain the NAICS industry classification information of the firms from the Employer Characteristics File of the LEHD, and biographic information such as sex, date of birth, and foreign-born status from the Individual Characteristics File of the LEHD.

\footnotetext{
${ }^{10}$ Duration model estimations are not computationally feasible alternatives for our analysis, because our identification strategy utilizes high dimensional fixed effects.
} 


\subsection{Key Outcomes of Interest}

Job-level mobility and earnings: For each job defined, we construct two dependent variables for examining the effect of CNC enforceability on a worker's mobility. The first is the length of the job spell defined as the log number of quarters the worker was employed at the firm. The second is a set of dummy variables for the job spell surviving a given length of time: a dummy variable with value 1 if the job spell survives until the 4th quarter of its spell, a dummy variable with value 1 if the job spell survives until the 8th quarter of its spell, and so on. We examine the survival of job spells up to the 32nd quarter (or eight years) from the start of the job spell. Using these dependent variables not only circumvents the right censoring of spells but also provides richer information on how CNC enforceability affects the distribution of job spells.

We examine the effect of CNC enforceability on wages, across job tenure by examining wages in various dimensions. Our primary measure is log wage at the 4th, 8th, ..., 32nd quarters of the job spell, CPI-adjusted to 2008 dollars. We also examine log cumulative wage at the 4th, 8th, ..., 32nd quarters of the job spell.

Mobility and earnings over employment history: Beyond the effect of CNC enforceability on the job-level outcomes, we examine its effect on workers' career outcomes across their employment history. In parallel to the analysis of job-level mobility and wages, we examine how CNC enforceability affects the cumulative number of jobs taken (in logs) and workers' cumulative earnings (in logs) at the worker level. Further, we extend our analysis to the workers' choice of switching states or industries to avoid or circumvent CNC enforceability, by examining the cumulative number of switches in states or switches in industries at the worker level (in logs). 
We examine these outcomes across the 4th, 8th, ...32nd quarters of workers' employment history. ${ }^{11}$

\subsection{The CNC Enforceability Measure}

A commonly used data source for the measure of CNC enforceability is Malsberger's (1996) series Covenants Not to Compete: A State by State Survey, which tracks the case law for each state along numerous dimensions of enforceability. Bishara (2011) and Garmaise (2011) each quantify these various dimensions of enforceability. We use the enforceability index developed in Starr (2016), which modifies the Bishara (2011) index by performing factor analysis to re-weight the seven dimensions of enforceability. The Starr-Bishara index has the advantage of removing the redundancy of the seven dimensions of enforceability and capturing a finer granularity of the way enforceability is construed along a spectrum of weak to strong enforceability. Figure A1 in the Online Appendix presents the enforceability index scores by state for 2009. Note that the enforceability index scores are normalized to have mean 0 and standard deviation of 1 in a sample where each state is given equal weight.

\section{Empirical Methodology}

We estimate the effect of CNC enforceability on high-tech workers' mobility and wages across the worker's job and career by exploiting the significant inter-state variation in the 2009 enforceability index scores. Specifically, we estimate the differential effect on the jobs (and workers) that are in high-tech industries compared with the effect on other jobs (and workers). As discussed earlier, we choose high-tech workers as our treatment group because these workers are relatively more likely to embody intellectual capital (as discussed in the literature, e.g., Marx

${ }^{11}$ For left-censored workers, the 4th, 8th, ..., 32nd quarters of the worker's employment history are measured starting from the first job that is not left censored. 
2011) and hence more likely to be affected by CNC enforceability. Indeed, while Starr, Bishara, and Prescott (2016) report a national signing rate of $18 \%$, the incidence rate for Computer, Mathematical, Engineering, and Architecture jobs is much higher, at 36\%. Further, studies of CNC litigations show that technology workers are frequently involved in such litigations (LaVan 2000) and a large literature in law and economics has focused on the effect of CNC enforceability on high technology workers (see review in Arnow-Richman 2001).

We use the industry (NAICS) classification of the employer to create a dummy variable for the job being in "Technology Industries." We use the definition of "Technology Industries" by Paytas and Berglund (2004), which classifies the NAICS industries into technology industries by employment of occupations that are science-and-engineering-intensive based on the occupation-NAICS employment concordance provided by the Bureau of Labor Statistics. We define "Technology Industries" at the three-digit NAICS code level, and jobs in "Technology Industries” are hereafter referred to as "high-tech jobs.” Industries that are not “Technology Industries” are referred to as “Other Industries," and jobs in "Other Industries” are referred to as “non-tech jobs” hereafter.

In all of our analyses, we use rich fixed effects, based on worker and job characteristics at the time the job spell starts. Each joint fixed effect defines a group of jobs that are common in terms of their three-digit NAICS codes, starting year, firm size group, starting wage group, starting age group of the worker, and gender of the worker. Firm size is the maximum number of quarterly workers employed at the firm in the year when the job spell started, grouped in quartiles. Starting wage is defined by a categorical variable, with eleven categories along the distribution of starting wages of jobs with the same three-digit NAICS codes. Starting age is the worker's age in the job's first year in quartiles in the distribution of starting ages for all jobs. 
Note that LEHD data does not contain detailed occupation or reliable education data for workers. To mitigate potential bias from unobserved heterogeneity on these characteristics, we use starting wages (defined as the second-quarter wage of each job) as a proxy for the initial level of general human capital of the worker, using a categorical variable defined within jobs with the same three-digit NAICS codes. That is, we presume to the extent that workers with the same age and gender starting at the same time in similar-sized firms in the same industry have different educational backgrounds or occupations, this should be reflected in the starting wage. Starting-year fixed effects are used to control for cohort-specific initial period shocks.

We then estimate the differential effect of CNC enforceability on the outcome variable of high-tech jobs using Equation (1):

$$
Y_{j}=\alpha+\delta C N C_{s} * I\{\text { Tech }\}_{j}+\Sigma_{s}+F E_{j}+\gamma f b_{j}+\varepsilon_{j}
$$

where the subscripts $j$ and $s$ are for job and state, respectively. These semi-parametric regressions use fully saturated specifications, and the job/worker characteristics fixed effects discussed above absorb the dummy variables that are absent in Equation (1). $Y_{j}$ denotes the dependent variables discussed above. $C N C_{S}$ is the 2009 CNC enforceability index measure of the state. $I\{\text { Tech }\}_{j}$ is 1 if the firm is in one of the “Technology Industries”. $F E_{j}$ denotes job/worker characteristics fixed effects. ${ }^{12} f b_{j}$ denotes whether the worker was foreign-born. We control for

\footnotetext{
${ }^{12}$ For the worker-level analysis on cumulative number of jobs taken, cumulative wages, and cumulative number of states (or industries), the CNC enforceability measure is that of the state in which the worker's first job is located. Likewise, the job-level variables and the job-level fixed effects are replaced with those of the first job; in other words, they are the initial characteristics of the first job.
} 
foreign-born status, as foreign-born employees are subject to visa-related employment eligibility constraints that may affect their mobility. $\Sigma_{s}$ denotes state fixed effects dummy variables.

Our coefficient of interest is $\delta$, which estimates the differential effect of CNC enforceability for high-tech jobs compared with non-tech jobs. This implements a cross-sectional pseudo difference-in-differences design similar to prior studies that exploit cross-state variation in enforceability by using a pseudo control group within each state to net out potential confounding state-level variables (Fallick, Fleischman, and Rebitzer 2006; Stuart and Sorenson 2003; Samila and Sorenson 2011; Garmaise 2011; Starr 2016; Starr, Balasubramanian, and Sakakibara 2016). ${ }^{13}$ This approach allows us to control for potential bias from omitted state-level variables that could be correlated with CNC enforceability.

In particular, focusing on the differential impact of CNC enforceability on technology workers relative to other workers allows us to include state fixed effects, which fully control for (fixed) state-level unobservables such as state policies, economic characteristics, and demographic characteristics that could be correlated with CNC enforceability and also with outcome variables such as mobility and wages (and hence could be potential sources of significant bias), so long as these unobservables impact outcome variables in a similar way across sectors. The cost is that we identify only the differential effect on high-tech jobs relative to non-tech jobs, so that baseline effects on non-tech jobs get subsumed by the state fixed effects.

\footnotetext{
${ }^{13}$ Garmaise (2011) also analyzes three within-state changes during our time period, but only two such changes occurred within our thirty-state sample. Because public disclosure of results requires at least three states, we are unable to utilize this variation to identify the effects of interest.
} 
Further, to the extent that non-tech jobs are also impacted by CNC enforceability, our estimates could be biased downward.

We extend this further to a pseudo triple-differences approach, by focusing on a subgroup of workers who are likely to be more strongly targeted for CNC enforcement. In particular, jobs with higher starting wages are likely to be more knowledge intensive reflecting higher levels of human capital. These workers are therefore likely to develop greater appropriable intellectual capital, and are therefore more likely to be affected by CNC enforceability (Starr, Bishara, and Prescott 2016). Specifically, we use a dummy variable for "high-initial-wage jobs” for the starting wage of the job being above the 98th percentile in the distribution of starting wages of jobs that have the same three-digit NAICS codes. We then examine the differential effect of CNC enforceability on high and low-initial-wage jobs within high-tech jobs, using Equation (2):

$$
\begin{aligned}
Y_{j}= & \alpha+\beta_{1} C N C_{s} * I\{\text { Tech }\}_{j} * I\{\text { High_Wage_Init }\}_{j}+\beta_{2} C N C_{s} * I\{\text { Tech }\}_{j} \\
& +\beta_{3} C N C_{s} * I\{\text { High_Wage_Init }\}_{j}+\Sigma_{s}+F E_{j}+\gamma f b_{j}+\varepsilon_{j}
\end{aligned}
$$

where $I\{\text { High_Wage_Init }\}_{j}$ denotes the dummy variable for the job being a high-initial-wage job. All other terms are as described for Equation (1) above. ${ }^{14}$

Our first coefficient of interest is $\beta_{1}+\beta_{3}$, which is the estimator of the differential effect of CNC enforceability for high-initial-wage jobs compared with low-initial-wage jobs, within high-tech jobs. Our second coefficient of interest is $\beta_{1}$, which is a pseudo difference-in-

\footnotetext{
${ }^{14}$ As discussed in Section 5.5, as an extension, we examine a specification that includes stateindustry (two-digit) fixed effects; this allows for identification of differential effects of CNC enforcement on high-initial-wage technology workers, even allowing for state-level omitted variables that could have differential impacts on outcomes (mobility and wages) across different industries, so long as the effects don't vary across wage categories within an industry.
} 
difference-in-differences (DDD) estimator of the differential CNC enforceability effect for hightech jobs relative to non-tech jobs, after differencing out common unobservables across highinitial-wage jobs and low-initial-wage jobs. The third coefficient of interest is $\beta_{1}+\beta_{2}$, which is the estimator of the differential effect of CNC enforceability for high-tech jobs compared with non-tech jobs, within high-initial-wage jobs. Throughout, standard errors are clustered at the state level to allow arbitrary correlation of the error terms within each state (Bertrand, Duflo, and Mullainathan 2004).

\section{Results}

\subsection{Mobility and Wage Across Job Tenure}

Table 1 presents the differential effect of CNC enforceability on mobility from estimating Equation (1). The column heads denote the dependent variables for each of the specifications. Table 1 shows that a one-standard-deviation increase in the enforceability score increases mean job spell duration by 1.5\% (Col 9). This mean effect is driven by rightward shifts in the job spell distribution in higher enforceability states beginning in year 2 (Col 2). A one-standard-deviation increase in enforceability increases the probability that a job spell lasts at least eight years by 0.5 percentage points (Col 8). Given that only $12.4 \%$ of all job spells last eight years, a onestandard-deviation increase in enforceability increases the likelihood that the job lasts at least eight years by $4 \%(0.5 / 12.4){ }^{15}$

To put these in context, assuming a uniform effect over the distribution of enforceability scores, if a previously non-enforcing state adopted the maximal enforceability policy (a difference of five standard deviations), these estimates suggest that mean job-spell length would

\footnotetext{
${ }^{15}$ Summary statistics for all dependent variables are presented in Online Appendix Table A1; the population mean for the dummy indicator of job spell surviving more than 32 quarters is 0.124 .
} 
rise by 7.5\% (markedly similar to the 8\% observed in Marx, Strumsky, and Fleming 2009) and the likelihood that jobs last at least eight years rises by $20 \%$. A graphic illustration of the coefficient estimates and the 95\% confidence intervals in Table 1 is provided in Figure A2. The increase in the effect on mobility over the tenure profile is consistent with employees gaining more intellectual capital and hence being more strongly targeted by firms for CNC enforcement.

Table 2 presents the differential effect of CNC enforceability on wages across job tenure using Equation (1). We observe a persistent wage suppressing effect. The differential effect ranges from $0.5 \%$ to $0.7 \%$ for high-tech jobs compared with non-tech jobs, suggesting that moving from a ban to maximal enforceability would reduce wages by $2.5 \%$ to $3.5 \%$ for the average technical worker. The coefficient estimates and the $95 \%$ confidence intervals are plotted in Figure A3. Unlike the tenure profile for mobility, the wage effect is relatively flat so the wage penalty effect of CNC is similar in log difference terms over the job tenure. Overall, comparing the wage penalty profile in Figure A3 to the mobility profile in Figure A2, the results are consistent with a reduction in bargaining power starting early in the job tenure of tech workers. The different patterns are consistent with a stronger effect of enforceability on increases in relationship-specific value (in Case 2A, where firm investments matter) as job spells increase (hence, the decline in exit propensity), but reduced bargaining power offsets potential gains to the employee (hence, keep the wage penalty relatively flat). ${ }^{16}$

Table 3 reports the differential effect of CNC enforceability on the mobility of highinitial-wage jobs relative to low-initial-wage jobs within high-tech jobs $\left(\beta_{1}+\beta_{3}\right)$, the differential

\footnotetext{
${ }^{16}$ Alternatively, the wage patterns may reflect intertemporal payment arrangements; e.g., the flatter wage penalty may reflect an initially lower wage penalty to offset future decline in outside options.
} 
effect of tech versus non-tech within high-initial-wage jobs $\left(\beta_{1}+\beta_{2}\right)$, and the pseudo DDD effect $\left(\beta_{1}\right)$ by estimating Equation (2). The dependent variables denoted in the column heads are the same as in Table 1.

We observe results that are consistent with those in Table 1, for both the differential effect estimate of high-initial-wage jobs relative to low-initial-wage jobs within high-tech jobs, the tech versus non-tech jobs within high-initial-wage jobs, and the pseudo DDD estimate. We find that among the high-tech jobs $\left(\beta_{1}+\beta_{3}\right)$, high-initial-wage jobs experience a higher likelihood of survival compared with low-initial-wage jobs throughout the job tenure by a magnitude ranging in $0.2 \%$ to $0.5 \%$, and a longer expected job spell (by $1.4 \%$ ) when enforceability scores increase by one standard deviation. Within high-initial-wage jobs, enforceability has a similar effect for high-tech jobs relative to non-tech jobs, resulting in 3.5\% longer job spells. The large and significant pseudo DDD estimate $\left(\beta_{1}\right)$ shows that the effect of CNC enforceability on mobility is greatest when workers are in both high-tech industry and high-initial-wage jobs. The key estimates and the 95\% confidence intervals are plotted in the Online Appendix Figures A4 to A6. The patterns suggest that the differential effect for highinitial-wage tech workers relative to low-initial-wage tech workers (Figure A4) is relatively flat. Relative to high-initial-wage workers in non-tech sectors, however, high-initial-wage tech workers see a sharp increase in the effect on mobility over the initial few (Figure A5), consistent with these workers gaining access to appropriable capital only over a period of two to three years, so that their mobility is relatively less restricted very early in the job tenure. This relative 
increase in the effect on mobility over the first few years of job tenure is then also seen in the triple difference profile in Figure A6. ${ }^{17}$

Table 4 presents the estimated differential effect of CNC enforceability on wages across job tenure of high-initial-wage jobs relative to low-initial-wage jobs within high-tech jobs, hightech jobs relative to non-tech jobs within high-initial-wage jobs, and the pseudo DDD effect. The dependent variables, the fixed effects, and the estimation samples are the same as those in Table 2. As in Table 2, we observe a persistent wage suppressing effect in all of the relevant comparisons. Among the high-tech jobs, the differential effect between high-initial-wage jobs and low-initial-wage jobs is estimated to be in the range of $2.9 \%$ to $5.0 \%$ throughout job tenure. Among high-initial-wage jobs, enforceability is associated with a differential tech effect between $1.5 \%$ in year 4 and $2.4 \%$ in year 8 . The comparison of the magnitude of the coefficients indicates that whether the workers are in high-initial-wage jobs or not is the driving factor of the wagesuppression effect. The coefficient estimates and the 95\% confidence intervals of the differential effects within high tech, within high-initial-wage jobs, and the pseudo DDD estimates are plotted in Online Appendix Figures A7, A8, and A9, respectively. All show a negative effect on wages that decreases over time.

${ }^{17}$ The inverted-U shape of the profile in Figure A6 suggests that high-initial-wage recruits in high-tech sectors see an increase in appropriable intellectual capital over the first few years, and then a depreciation of such capital over time, so that they may be most strongly targeted for mobility restriction by employers in the mid-range of the eight-year job span we analyze here. To the extent that the profile of the effect of enforceability on mobility reflects underlying "value" of the employee to the firm, this is reminiscent of the value profile discussed in Lazear and Gibbs (2014, 82-85). 
Next, in Tables 5 and 6, we examine the differential effect of CNC enforceability on payouts to workers across job tenure using alternative measures of compensation: cumulative wage and wage growth. We measure cumulative wage as the log of cumulative wage at 4th, 8th, ..., 32nd quarter of the job spell since the job spell started. We measure wage growth as the difference between the log of quarterly wages at 4th, 8th, ..., 32nd quarters of the job spell and the log of initial wage of the job. Table 5 and Table 6 repeat Table 2 and Table 4, respectively, except that the alternative measures of wage are used, instead of the wage in levels.

Table 5 shows that the differential effect of CNC enforceability on cumulative wage gradually increases over job tenure, and that the differential effect on wage growth displays a Ushaped pattern. To provide context for the coefficient estimates, the results in Panel A suggest that if a non-enforcing state adopted the most extreme enforcement policies, cumulative earnings eight years into a job would be roughly $5 \%$ lower for the average tech worker relative to a nontech worker. In Table 6, columns 1 through 4 show that the estimates of the differential effect on cumulative wage for high-initial-wage jobs within high-tech jobs, the differential effect between high-tech and non-tech jobs within high-initial-wage jobs, and the pseudo DDD estimates on cumulative wages increase gradually over job tenure. The estimated effects on wage growth are presented in columns 5 through 8 , which also indicates that the impact gradually increases as the job spell becomes longer, for the differential effect for high-initial-wage jobs within high-tech jobs, for the differential effect for high-tech jobs within high-initial-wage jobs, and for the pseudo DDD estimates. These results are consistent with the wage estimates reported in Table 4. Together, the results in this section show consistent patterns that CNC enforceability is associated with longer job-spells, and with lower wages throughout these job spells. 


\subsection{Career Outcomes Across Employment History}

So far, we have examined how CNC enforceability affects mobility and wage at the joblevel. In this subsection, we examine the mobility and earnings outcomes at the worker-level across the worker's employment history. ${ }^{18}$

We estimate Equation (1) across workers’ employment history, using the cumulative number of jobs each worker has taken to examine the differential effect on mobility, and using the cumulative earnings of the worker to examine the differential effect on earnings. These dependent variables are examined at the 4th, 8th, ..., 32nd quarters since the worker started his or her employment history. All right-hand-side variables, including the high-tech dummy, the CNC enforceability score, and fixed effects, are those of the worker's first job in the dataset. Thus, we estimate how outcomes over the career of a worker are different depending on whether he or she started in a high-CNC-enforceability state relative to a similar age-gender worker with similar starting wage in a similar sized firm in the same industry starting his or her first job in the same year in a low-enforceability state. ${ }^{19}$

${ }^{18}$ Note that because the LEHD covers only thirty states, examining worker-level outcomes (unlike job-level outcomes) potentially carries measurement error due to movement of workers into non-covered states, which may attenuate our estimated coefficients. See Sections 5.4 and 5.5 for some evidence on the lack of correlation between the missing states and enforceability.

${ }^{19}$ We do not estimate the enforceability effect using Equation (2) for the worker-level outcomes, as the high initial wage dummy variable is defined by the worker's first job that appears in the dataset, and therefore is correlated with age for the worker-level data. Hence, estimation of Equation (2) at the worker-level would yield results largely driven by workers who enter the LEHD data as old workers. 
Table 7 reports the estimation results. For both mobility (Panel A) and earnings (Panel B), we observe persistent differential effects of CNC enforceability across employment history, similar to the effects on job-level outcomes. The mobility-constraining effect is gradually increasing across employment history, such that a one-standard-deviation increase in enforceability is associated with a $2.1 \%$ decrease in the number of jobs after eight years, and we find a gradually increasing and then decreasing wage-suppressing effect across employment history.

One notable distinction between the cumulative earnings regressions at the career level (Table 7) versus at the job level (Table 5) is that the latter are conditional on the employee staying in the same job until the tenure under consideration (e.g., the end of quarter 24 analysis in Table 5 is conditional on workers staying on until quarter 24). The mobility results (Tables 1 and 3) suggest that high-tech workers have longer job spells than non-tech workers. Then the estimated effects for the job-level wage regressions could be impacted by a composition effect, with the direction of the effect depending on whether the workers that quit in low-enforceability states would have had higher or lower earnings if they had stayed on (counterfactual) than the average for survivors. To the extent that the more productive workers are more likely to find outside opportunities, the job-level analysis in Table 5 could be biased toward zero. Indeed, the larger magnitudes of the effects in Panel B of Table 7 compared with those in Panel A of Table 5 suggests this to be the case.

\subsection{State- and Industry-Switching Behavior Across Employment History}

If variation in CNC enforceability were indeed material as our previous results suggest, one way to circumvent CNC enforceability would be to transfer to jobs outside the geographic scope of the CNC (e.g., the state) or to jobs in other industries. In this subsection, we examine 
the total number of state switches, industry switches, and state but not industry switches across the workers' employment history. The analysis is conducted at the worker-level, similar to the analysis in Section 5.2, and we use the same specifications as those in Table 5, except we replace the dependent variables with $\log (1+$ cumulative number of state switches $), \log (1+$ cumulative number of industry switches), and log (1 + cumulative number of state-but-not-industryswitches). We define state and industry switches by changes in state and the three-digit NAICS code of the worker's employer, respectively.

In Table 8, we observe a greater frequency of state switches for high-tech workers with initial employment in a high-enforceability jurisdiction, compared with non-tech workers (Panel A). By contrast, greater enforceability is associated with a negative differential effect on the number of industry switches for workers in high-tech industries across their employment history (Panel B). Panel C shows that what is driving these contrasting results is that greater enforceability is associated with workers switching states but not industries. ${ }^{20}$

\footnotetext{
${ }^{20}$ We also examined how CNC enforceability affects the worker's decision to switch state (or industry) at the point of job transition. For this analysis, we estimate Equation (1) having outcome variables as the binary choice of switching state (or industry). Each observation in the estimation sample is the worker-job-year-quarter observation at the quarter of job transition. Thus the regressions estimate the differential effect of CNC enforceability on the probability of switching state (or industry), conditioning on job transition, and controlling for the job characteristics of the pre-transition job. The results, reported in Online Appendix Table A5, show that workers in high-tech industries are more likely to switch state but not industry, and they are less likely to switch industry but not state, at job transitions in high-CNC-enforceability states. This set of results is consistent with the results in Table 8.
} 
These results suggest that while tech workers in high-enforceability states are more likely to switch states to avoid enforcement, they appear to have greater industry-specific capital, so they are more likely to stay within the industry when they change jobs. This is consistent with greater investment in industry-specific human capital (or endogenous location of activities requiring industry-specific human capital) by firms in high-CNC locations (Marx 2011; Starr, Ganco, and Campbell 2016). Taken together with the baseline results of the significantly lower frequency of job switches by tech workers in high-enforceability jurisdictions, these results suggest that CNC enforceability places noticeable constraints on the frequency and direction of worker mobility across jobs.

\subsection{Unemployment or "Missing” Spells}

While the above specifications consider movements of workers across states and industries, workers may also become unemployed as a result of CNC enforceability. For example, if an employee leaves for a competitor, the competitor can subsequently be sued by the employee's former employer, and the competitor could decide against hiring the employee (Viswanatha 2016). We use Equation (1) with the dependent variable as the log number of quarters between observed jobs in the LEHD. Such "missing" spells in the data may be a result of either unemployment or movement into a non-LEHD state. The dummy variable for high-tech jobs is that of the job before the missing spell, and the CNC enforceability score is similarly applied to the job before the missing spell. The estimation sample consists of all missing spells between non-continuous job spells. Online Appendix Table A6 reports the estimation results, where we observe small negative but insignificant effects. That is, we do not find any evidence for CNC enforceability being related to an increase in unemployment or "missing" spells. 


\subsection{Robustness Checks}

We perform several checks to assess the robustness of our results.

Local labor market thickness: First, we redo our main analysis by controlling for two potentially confounding effects: local labor market thickness and industry-specific policies within each state. In particular, one might be concerned that unobserved local labor market thickness may be (incidentally) negatively correlated with enforceability, but also correlated with greater wages and mobility (as thicker markets could imply greater competition among labor-demanding firms). In the Online Appendix Table A2, we repeat our main analysis of within-job mobility and wages controlling for labor market thickness proxied using total employment in state/three-digit NAICS code/year (in logs). The results are remarkably similar to the baseline results.

Controlling for state-industry effects in pseudo triple-difference analysis: A related concern is that states may adopt industry-specific policies or otherwise treat specific industries differently. For example, if the technology sector has differences in characteristics across states in ways correlated with CNC enforceability, it could bias estimates from Equations (1) or (2). To account for this possibility, as discussed earlier, we further saturate the specification examining differential effects on high-initial-wage tech workers (Equation 2) with state-industry fixed effects. The results, presented in Online Appendix Tables A3 and A4, confirm that the differential effects of CNC on high-initial-wage workers observed in the baseline results (Tables 3 and 4) are not spurious artefacts of variation in industry-specific policies correlated with CNC enforceability across states.

Using CNC ranks instead of raw scores: Another potential concern is that California's large economy and near-complete CNC non-enforceability (an outlier among the CNC scores used in baseline analysis) could be inordinately influencing the results. We therefore repeat our analyses 
in Section 5.1, using ranks of the 2009 CNC enforceability index scores, which is free from extreme values by construction. The 2009 CNC enforceability index score ranks are assigned integer values of 1 to 50 and are normalized to have mean 0 and standard deviation 1 across the fifty state values. Larger values correspond to stronger CNC enforceability and smaller values correspond to weaker CNC enforceability. In results presented in the Online Appendix (Table A7 Panels A and B which repeat Table 1 and Table 2, and Table A8 which repeats Tables 3 and Table 4), we find that estimates using CNC ranks are very similar to those using CNC scores in terms of statistical significance and signs, and that the magnitudes are larger.

Balance of enforceability measures across missing and available states: Because the LEHD data we had access to does not cover all fifty US states, there could be a bias as a result of workers' relocations to missing states. For example, when a worker is transferred to an establishment of the same firm that is located in a non-LEHD state, we lose track of the worker, potentially yielding a right-censoring in the spell measure. If firms relocate workers from low-enforceability states to high-enforceability states to protect their knowledge, and if the missing states have higher levels of CNC enforceability, there would be a positive bias in the estimated effect. However, a $t$-test for difference in the enforceability index scores between the states included in the LEHD and the states not included in the LEHD yield a $p$-value of 0.83 , suggesting there is no significant difference in mean CNC enforceability scores across states in and out of the LEHD sample, which alleviates such a concern.

Robustness of job spell analysis to using alternative samples: Finally, due to right-censoring, we restricted the sample to jobs that started in the year 2000 or earlier for our analysis of job spell lengths. In an unreported analysis, we find that the results for the log of job spells analysis are robust to the sample of non-right censored jobs that started in the year 2000 or earlier. We also 
repeat columns (1)-(8) of Table 1 and Table 3 on the sample of jobs that started in year 2000 or earlier, and find that the results are robust. The estimation results are available upon request.

\section{Discussion}

This study uses matched employer-employee data to examine how CNC enforceability affects the rate and direction of employee mobility and the time path of wages both within a job and across the employee’s career. Using a sample-splitting-based pseudo difference-indifferences approach that employs fine-grained job-, individual-characteristics, and state fixed effects, we compare job spells (and wages) in "High Technology” industries with those in “Other Industries.” We find that stricter CNC enforceability is associated with longer job spells, a greater likelihood of leaving the state, and a reduced propensity for cross-industry movement. Importantly, we also find that compared with their peers in low-enforceability states, workers in states with high enforceability receive reduced wages and exhibit a lower wage growth throughout a given job as well as over their career.

Our finding of longer job spells, which is consistent with predictions generated by our model (see Theory Appendix) under most scenarios, is also consistent with prior studies of CNC enforceability and mobility such as Marx, Strumsky, and Fleming (2009), Marx, Singh, and Fleming (2015), and Garmaise (2011). The two former studies find that inventor mobility was reduced and redirected out of state following Michigan’s reversal of its policy not to enforce CNCs. Based on within-state changes in enforceability, Garmaise (2011) finds reduced intraindustry mobility among top executives. Relative to these studies, our examination of job spells covers a significantly larger and less-selective sample that tracks mobility with greater accuracy.

Further, our findings fill two important gaps related to (i) joint state-industry switching behavior and (ii) variations in the effect of CNC enforceability over job tenure. Regarding 
switching, we find that the increased propensity to move across states but the decreased propensity to switch across industries is explained primarily by individuals who leave the state but stay in the same industry. These results are consistent with greater investment in industryspecific human capital (or endogenous location of activities requiring industry-specific human capital) by firms in high-enforceability locations (Marx 2011; Starr, Ganco, and Campbell 2016).

Along the temporal dimension, we find that the impact of CNC enforceability is lowest at short tenures, but rises at longer tenures. Table 1 shows that the enforceability-related increase in survival probability of a job spell at 4 quarters is -0.02 percentage points, far less than at 24 quarters (0.57 percentage points). The pseudo-DDD coefficients in Table 3 shows a similar pattern, consistent with CNC being enforced only after workers gain or learn significant appropriable intellectual capital, indicating that CNC enforceability has a smaller effect early in the job tenure. ${ }^{21}$ The higher impact at mid-tenure is consistent with Lazear and Gibbs (2014, 8285), who suggest the value of a worker to a firm is highest for mid-career workers, making it more likely that firms enforce CNCs on such workers.

Lower mobility alone does not imply a negative effect on workers. Workers may trade off mobility in return for higher wages resulting from increased firm investments in their human capital. For instance, Lavetti, Simon, and White (2014) find that physicians who sign CNCs have higher earnings and earnings growth. In contrast, we find that stricter CNC enforceability is associated with wage-suppressing effects, both one year into the job and throughout the employee's tenure. In this respect, our results are similar to those in Garmaise (2011) and Starr,

\footnotetext{
${ }^{21}$ Further, in a Jovanovic-type learning/matching model, initial separations may be a signal of lack of fit between the worker and the firm, and such separations may in fact be mutually beneficial and unrestricted by the firm, even when CNC is enforceable.
} 
Ganco, and Campbell (2016). For example, compared with low-initial-wage jobs within tech industries, a one-standard-deviation increase in enforceability is associated with a $4 \%$ lower average wage after 28 quarters in high-initial-wage tech jobs (Table 4, column 7). The cumulative effect of this wage suppression over a seven-year period is $4.4 \%$ lower cumulative earnings, based on the coefficients in Table 6. A related possibility is that wages at the beginning of a job (which get subsumed in the starting wage fixed effects in our specifications) are higher in high-enforceability states, so workers in such states do not suffer any net wage losses over the entire job spell. However, we do not find any supporting evidence for this line of argument. Rather, subject to the caveat that data on detailed occupational characteristics is unavailable, we find that CNC enforceability is associated with significantly lower initial wages (Online Appendix Table A9).

Our last finding regarding the effects of CNC enforceability over the career of the employee suggests that simply starting a job in a higher enforceability state—regardless of whether the individual eventually leaves that state—is associated with reduced earnings up to eight years later. These findings highlight the potential that the initial legal conditions of employment have persistent effects on future earnings, similar to how entering the job market in a recession hurts those who are slow to move to better jobs (Oreopoulus, von Wachter, and Heisz 2012). Indeed, the mechanism highlighted in Oreopoulus, von Wachter, and Heisz (2012) is the rate at which workers move to better jobs, which is closely related to the role that CNC enforceability plays as a within-industry mobility friction.

The theoretical model (Theory Appendix) shows that our empirical findings are plausible under a number of scenarios. The model clarifies that our results do not necessarily imply a stronger role for firm investments in creating firm-worker relationship value in tech industries. In 
particular, our results do not rule out relationship capital being exogenous, or individual investments being more important. Lower exit rate and lower wages in high-enforceability states could be accompanied by lower knowledge capital resulting from lower individual investment, with firms gaining from obtaining a larger share of the smaller relationship value. ${ }^{22}$

Taking our results together, it appears unambiguous that CNC enforceability lowers worker welfare, consistent with CNC enforceability reducing workers' bargaining power relative to the firm, and "locking” them into their jobs, as argued by Arnow-Richman (2001, 2006), and consistent with the lack of negotiation over CNCs observed in Starr, Bishara, and Prescott (2016). To the extent that lower wages over workers' careers reflects decline in match quality between workers and firms, our results suggest that allocative efficiency is lower when there is higher CNC enforceability. Further, if mobility generates knowledge spillover effects, as argued in the literature (Gilson 1999), then potential gains from increased firm investments in human capital (if any) have to be significantly high to offset these negative welfare effects.

We conclude with a brief discussion of future avenues for research. To keep the study focused, we did not examine any inter-industry heterogeneity. There may be industries where high enforceability benefits workers (e.g., as Lavetti, Simon, and White 2014 find among physicians). It would be interesting to explore this heterogeneity, to shed light on industry characteristics that moderate the impact of CNC enforceability. Also, as for most other studies,

${ }^{22}$ We note that the survey evidence in Starr (2016) does not find evidence for lower worker training investments in high-enforceability states. If enforceability does incentivize firm investments and increase relationship productivity, then our findings suggest a strong negative impact of CNC enforceability on worker bargaining power (see the discussion of Case 2A in the Theory Appendix). 
we cannot identify in the data who is and who is not bound by a CNC. Thus, we must aggregate the effect of CNC enforceability on those who do and do not sign, which likely attenuates the overall results and makes it difficult to isolate the exact mechanisms underlying the observed relationships. Disentangling the extent to which these effects are driven by those who sign and those who do not sign is an important avenue for future research.

For policymakers, the lack of time-series data on the actual use of CNCs means we cannot assess the role of potential increases in CNC usage over time in (at least partially) explaining the decline in U.S. labor market dynamism and wage stagnation (Davis and Haltiwanger 2014, Hyatt and Spletzer 2013; Biden 2016; Council of Economic Advisers 2016). Assessing this possibility with data on who signs CNCs is another avenue for future research. Nevertheless, our results suggest that reductions in CNC enforceability could be one effective lever available to lawmakers for increasing labor market dynamism.

Our findings also highlight a potential similarity between labor market collusion and the enforceability of CNCs. The "gentleman’s agreements” signed by Apple, Google, and many other tech companies in California to not recruit each other's employees served to reduce both wage competition and mobility between competitors (Helft 2009). ${ }^{23}$ Mukherjee and Vasconcelos (2012) model these agreements as alternate mechanisms for extracting surplus from productive workers, and our findings suggest that the outcomes for workers from high CNC enforceability may be somewhat similar to those due to labor market collusion. Our results suggest that for tech workers, particularly high-initial-wage tech workers, variation in CNC enforceability does matter

\footnotetext{
${ }^{23}$ In his deposition during the Department of Justice investigation into the Silicon Valley gentleman’s agreements, George Lucas said “[We] could not get into a bidding war with other companies because we don't have the margins for that sort of thing.”
} 
for both mobility and wage outcomes; therefore (potentially undetected) labor market collusion in low-enforceability states does not fully replicate the effects of formal CNC enforceability mechanisms. Nevertheless, there could be variations across sectors in the sustainability of labor market collusion (e.g., state-industries with very high concentration), which could provide an interesting source of heterogeneity worth further study.

Finally, our findings suggest a potential impact of CNC enforceability on aggregate productivity, which could be explored in future work. In particular, our results suggest that CNC enforceability generates a real mobility-lowering friction, not offset by side payments. As discussed above, our finding of lower wages in high-enforceability states may suggest poorer worker-firm matching, suggesting that CNC enforceability may reduce allocative efficiency in a manner similar to other frictions found to impede labor reallocation in e.g., the literature on employment protection (Autor, Kerr and Kugler 2007; Petrin and Sivadasan 2013).

\section{REFERENCES}

Arnow-Richman, Rachel S. 2001. "Bargaining for Loyalty in the Information Age: A Reconsideration of the Role of Substantive Fairness in Enforcing Employee Noncompetes." Oregon Law Review 80(4): 1163-1244.

Arnow-Richman, Rachel. 2006. "Cubewrap Contracts and Worker Mobility: The Dilution of Employee Bargaining Power Via Standard Form CNCs.” Michigan State Law Review: 963-992.

Autor, D. H., Kerr, W. R. and Kugler, A. D. (2007), “Does Employment Protection Reduce Productivity? Evidence From US States,” The Economic Journal, 117: 189-217.

Bartel, Ann P. 1994. "Productivity gains from the implementation of employee training programs." Industrial relations: a journal of economy and society 33(4): 411-425. 
Becker, Gary S. 1962. “Investment in Human Capital: A Theoretical Analysis.” Journal of Political Economy 70(5), pt. 2 (October): 9-49.

Bertrand, Marianne, Esther Duflo, and Sendhil Mullainathan. 2004. "How Much Should We Trust Differences-in-Differences Estimates?” The Quarterly Journal of Economics 119(1): 249-275.

Biden, Joseph. “How Have Non-Competes and Wage Collusion Affected You?” Facebook (2016). Accessed at: https://www.facebook.com/VicePresidentBiden/posts/1786398901588706:0.

Bishara, Norman. 2011. "Fifty Ways to Leave Your Employer: Relative Enforcement of Covenants Not to Compete, Trends, and Implications for Employee Mobility Policy.” University of Pennsylvania Journal of Business Law 13(3): 751-795.

Callahan, Maureen B. 1985. “Post-Employment Restraint Agreements: A Reassessment.” University of Chicago Law Review 52(3): 703-728.

Council of Economic Advisers. 2016. Economic Report of the President \& the Annual Report of the Council of Economic Advisers. February 2016.

Davis, Steven J., and John Haltiwanger. 2014. “Labor market fluidity and economic performance.” National Bureau of Economic Research Working Paper, No. w20479.

Fallick, B., C. Fleischman, and J. Rebitzer. 2006. “Job-Hopping in Silicon Valley: Some Evidence Concerning the Micro-Foundations of a High Technology Cluster.” Review of Economics and Statistics 88:472-481.

Garmaise, Mark. 2011. “Ties That Truly Bind: Non-competition Agreements, Executive Compensation, and Firm Investment.” Journal of Law, Economics, and Organization, 27: $376-425$. 
Gilson, R. 1999. “The Legal Infrastructure of High Technology Industrial Districts: Silicon Valley, Route 128, and Covenants Not to Compete.” New York University Law Rev. 74:575-629.

Gruber, Jonathan, and Brigitte Madrian. 1994. "Health insurance and job mobility: The effects of public policy on job-lock." Industrial \& Labor Relations Review 48, no. 1: 86-102.

Helft, Miguel. 2009. “Unwritten Code Rules Silicon Valley Hiring,” New York Times.

Hyatt, Henry R., and James R. Spletzer. 2013. “The Recent Decline in Employment Dynamics.” IZA Journal of Labor Economics, Vol. 2: Iss. 3: 1-21.

Hyde, Alan. 2003. Working in Silicon Valley: Economic and Legal Analysis of a High-Velocity Labor Market. Armonk, NY: M.E. Sharpe.

LaVan, Helen. 2000. "A logit model to predict the enforceability of noncompete agreements." Employee Responsibilities and Rights Journal 12, no. 4: 219-235.

Lavetti, K., C. Simon, and W. White. 2014. "Buying Loyalty: Theory and Evidence from Physicians.” Working Paper.

Lazear, Edward P. 2009. “Firm-Specific Human Capital: A Skill-Weights Approach,” Journal of Political Economy. 117, no.5: 914-940.

Lazear, Edward P. and Mike Gibbs. 2014. Personnel Economics in Practice, 3rd Edition, Wiley. Lobel, Orly. 2013. “Talent Wants to be Free: Why We Should Learn to Love Leaks, Raids, and Free Riding.” Yale University Press.

Malsberger, B. 1996. Covenants Not to Compete: A State by State Survey. Washington, DC: Bureau of National Affairs.

Marx, M. 2011. "The Firm Strikes Back: Non-Compete Agreements and the Mobility of Technical Professionals.” American Sociol. Rev. 76(5): 695-712. 
Marx, Matt, Deborah Strumsky and Lee Fleming. 2009. "Mobility, Skills, and the Michigan Non-Compete Experiment.” Management Science 55: 875-89.

Marx, M., J. Singh, and L. Fleming. 2015. "Regional Disadvantage? Employee Non-Compete Agreements and Brain Drain.” Research Policy (44): 394-404.

Mukherjee, Arijit and Luis Vasconcelos. 2012. "Star Wars: Exclusive Talent and Collusive Outcomes in Labor Markets,” The Journal of Law, Economics, \& Organization, 28(4): 754-782.

Oreopoulos, Philip, Till von Wachter and Andrew Heisz. 2012. "The Short- and Long-Term Career Effects of Graduating in a Recession." American Economic Journal: Applied Economics, 4(1): 1-29.

Paytas, Jerry, and Dan Berglund. 2004. “Technology industries and occupations for NAICS industry data." Pittsburgh: Carnegie Mellon Center for Economic Development and State Science and Technology Institute.

Petrin, Amil and Jagadeesh Sivadasan, 2013. "Estimating Lost Output from Allocative Inefficiency, with Application to Chile and Firing Costs,” The Review of Economics and Statistics, March 2013, Vol. 95, No 1, 286-301.

Posner, E., A. Triantis, and G. Triantis. 2004. "Investing in Human Capital: The Efficiency of Covenants Not to Compete.” Working Paper, University of Virginia Law School.

Rajan, R., and L. Zingales. 2001. "The Firm as a Dedicated Hierarchy: A Theory of the Origins and Growth of Firms.” Quarterly Journal of Economics Vol. 116 Issue 3: 805-851.

Romer, Paul M. 1989. "Human capital and growth: theory and evidence.” National Bureau of Economic Research Working Paper, No. w3173. 
Rubin, Paul H.; Shedd, Peter. 1981. “Human Capital and Covenants Not To Compete.” Journal of Legal Studies, Vol. 10 Issue 1: 93-110.

Samila, S., and O. Sorensen. 2011. "CNC Covenants: Incentives to Innovate or Impediments to Growth.” Management Science 57(3): 425-438.

Starr, Evan. 2016. “Consider This: Training, Wages, and the Enforceability of Covenants Not to Compete.” Working Paper.

Starr, Evan, Natarajan Balasubramanian, and Mariko Sakakibara. 2016. "Screening Spinouts? How CNC Enforceability Affects the Creation, Growth, and Survival of New Firms.” Management Science forthcoming.

Starr, Evan, Norman Bishara, and J. Prescott. 2016. "Noncompetes in the US Labor Force.” Working Paper.

Starr, Evan P., Martin Ganco, and Benjamin A. Campbell. 2016. "Redirect and Retain: How Firms Capitalize on Within and Across Industry Mobility Frictions.” Working paper.

Sterk, Stewart E. 1993. "Restraints on Alienation of Human Capital.” Virginia Law Review 79(2): 383-460.

Stuart, T., and O. Sorenson. 2003. "Liquidity Events and the Geographic Distribution of Entrepreneurial Activity.” Admin. Sci. Quart. 48(2): 175-201.

Viswanatha, Aruna. 2016. “Noncompete Agreements Hobble Junior Employees: A young journalist gets in a bind when she tries to move on to a new job.” Wall Street Journal.

Zillman, Claire. 2015. "Hawaii ban on noncompetes leaves out a huge chunk of workers" Fortune. Accessed at: http://fortune.com/2015/07/08/hawaii-noncompete-ban/. 


\section{Table 1. Effect of CNC on High-Tech Workers' Mobility}

This table reports the differential treatment effect of CNC enforceability on mobility by industry (high-tech jobs vs. non-tech jobs). The dependent variables are dummy variables for the job spell surviving at $4^{\text {th }}, \ldots, 32^{\text {nd }}$ quarter of the job spell for columns (1)-(8), and the log of length of job spells in number of quarters for column (9). CNC Score is measured as the 2009 CNC enforcement index scores. Estimation samples are all jobs that are not right censored by the quarter for columns (1)-(8), and all jobs that started its spell in year 2000 or earlier for column (9). All standard errors are clustered by state. ${ }^{* * *}, *^{* *}$, and ${ }^{*}$ denote significance levels of $1 \%, 5 \%$, and $10 \%$, respectively.

\begin{tabular}{|c|c|c|c|c|c|c|c|c|c|}
\hline $\begin{array}{l}\text { Dependent Variable: } \\
\text { Job spell survival at }\end{array}$ & $\begin{array}{c}\text { (1) } \\
\text { 4th qr }\end{array}$ & $\begin{array}{l}\text { (2) } \\
\text { 8th qr }\end{array}$ & $\begin{array}{c}\text { (3) } \\
\text { 12th qr }\end{array}$ & $\begin{array}{c}\text { (4) } \\
\text { 16th qr }\end{array}$ & $\begin{array}{c}(5) \\
\text { 20th qr }\end{array}$ & $\begin{array}{c}\text { (6) } \\
\text { 24th qr }\end{array}$ & $\begin{array}{c}\text { (7) } \\
\text { 28th qr }\end{array}$ & $\begin{array}{c}\text { (8) } \\
\text { 32th qr }\end{array}$ & $\begin{array}{c}(9) \\
\text { Ln(job-spell) }\end{array}$ \\
\hline Tech X CNC Score & $\begin{array}{r}-0.0002 \\
(0.0008)\end{array}$ & $\begin{array}{r}0.0033^{* * *} \\
(0.0011)\end{array}$ & $\begin{array}{r}0.0040^{* * *} \\
(0.0009)\end{array}$ & $\begin{array}{r}0.0046^{* * *} \\
(0.0012)\end{array}$ & $\begin{array}{r}0.0051^{* * *} \\
(0.0009)\end{array}$ & $\begin{array}{r}0.0057^{* * *} \\
(0.0009)\end{array}$ & $\begin{array}{r}0.0046 * * * \\
(0.0008)\end{array}$ & $\begin{array}{r}0.0052^{* * *} \\
(0.0007)\end{array}$ & $\begin{array}{r}0.0152 * * * \\
(0.0027)\end{array}$ \\
\hline \# of observations & 12984300 & 12425700 & 11971100 & 11602500 & 11334900 & 11127400 & 10861700 & 10661700 & 6492100 \\
\hline R-squared & 0.2108 & 0.1741 & 0.1731 & 0.1768 & 0.1817 & 0.1836 & 0.1831 & 0.1885 & 0.2113 \\
\hline Fixed Effects & \multicolumn{9}{|c|}{ State + [Industry - Starting Year - Firm Size - Starting Wage - Starting Age - Sex] } \\
\hline Sample & \multicolumn{8}{|c|}{ All jobs that are not right censored by the quarter } & $\begin{array}{l}\text { Spell started } \\
2000 \text { or earlier }\end{array}$ \\
\hline
\end{tabular}

\section{Table 2. Effect of CNC on High-Tech Workers’ Wage across Job Tenure}

This table reports the differential treatment effect of CNC enforceability on wage across job tenure by industry (high-tech jobs vs. non-tech jobs). The dependent variables are the log of quarterly wages at $4^{\text {th }}, \ldots, 32^{\text {nd }}$ quarter of the job spell. CNC Score is measured as the 2009 CNC enforcement index scores. All standard errors are clustered by state. ${ }^{* * *}, * *$, and $*$ denote significance levels of $1 \%, 5 \%$, and $10 \%$, respectively.

\begin{tabular}{|c|c|c|c|c|c|c|c|c|}
\hline Dependent Variable: & $(1)$ & $(2)$ & (3) & (4) & (5) & (6) & (7) & (8) \\
\hline Log of wage at xth quarter & 4th qr & 8th qr & 12th qr & 16th qr & 20th qr & 24th qr & 28th qr & 32th qr \\
\hline Tech X CNC Score & $\begin{array}{r}-0.0057^{* * *} \\
(0.0006)\end{array}$ & $\begin{array}{r}-0.0066^{* * *} \\
(0.0006)\end{array}$ & $\begin{array}{r}-0.0068^{* * *} \\
(0.0007)\end{array}$ & $\begin{array}{r}-0.0069 * * * \\
(0.0008)\end{array}$ & $\begin{array}{r}-0.0061^{* * *} \\
(0.0008)\end{array}$ & $\begin{array}{r}-0.0054^{* * *} \\
(0.0009)\end{array}$ & $\begin{array}{r}-0.0061^{* * *} \\
(0.0012)\end{array}$ & $\begin{array}{r}-0.0057 * * * \\
(0.0016)\end{array}$ \\
\hline \# of observations & 10904200 & 7397200 & 5399500 & 4048400 & 3145300 & 2478900 & 1858400 & 1412600 \\
\hline R-squared & 0.6726 & 0.6090 & 0.5764 & 0.5570 & 0.5429 & 0.5323 & 0.5237 & 0.5114 \\
\hline Fixed Effects & \multicolumn{8}{|c|}{ State + [Industry - Starting Year - Firm Size - Starting Wage - Starting Age - Sex] } \\
\hline Sample & \multicolumn{8}{|c|}{ All continuing jobs in the quarter } \\
\hline
\end{tabular}




\section{Table 3. Effect of CNC on Mobility: Sub-Samples by Industry and Initial Wage}

This table reports the differential treatment effect of CNC enforceability on mobility across sub-samples by industry (high-tech jobs vs non-tech jobs) and initial wage (high-initial-wage jobs vs low-initial-wage jobs). High-initial-wage jobs are jobs whose starting wage is above the 98th percentile in the distribution of starting wages of jobs that have the same three-digit NAICS codes. The dependent variables are dummy variables for the job spell surviving at $4^{\text {th }}, \ldots . ., 32^{\text {nd }}$ quarter of the job spell for columns (1)-(8), and the log of length of job spells in number of quarters for column (9). CNC Score is measured as the 2009 CNC enforcement index scores. Estimation samples are all jobs that are not right censored by the quarter for columns (1)-(8), and all jobs that started its spell in year 2000 or earlier for column (9). All standard errors are clustered by state. ***, **, and * denote significance levels of $1 \%, 5 \%$, and $10 \%$, respectively.

\begin{tabular}{|c|c|c|c|c|c|c|c|c|c|}
\hline $\begin{array}{l}\text { Dependent Variable: } \\
\text { Job spell survival at: }\end{array}$ & $\begin{array}{c}(1) \\
\text { 4th qr }\end{array}$ & $\begin{array}{c}(2) \\
\text { 8th qr }\end{array}$ & $\begin{array}{c}\text { (3) } \\
12 \text { th qr }\end{array}$ & $\begin{array}{c}\text { (4) } \\
\text { 16th qr }\end{array}$ & $\begin{array}{c}(5) \\
\text { 20th qr }\end{array}$ & $\begin{array}{c}(6) \\
\text { 24th qr }\end{array}$ & $\begin{array}{c}\text { (7) } \\
\text { 28th qr }\end{array}$ & $\begin{array}{c}\text { (8) } \\
\text { 32th qr }\end{array}$ & $\begin{array}{c}\text { (9) } \\
\text { Ln(job-spell) } \\
\end{array}$ \\
\hline $\begin{array}{l}\text { Tech X High-initial-wage } \\
\text { X CNC Score }\left(\beta_{1}\right)\end{array}$ & $\begin{array}{r}0.0048 * * * \\
(0.0010)\end{array}$ & $\begin{array}{r}0.0099 * * * \\
(0.0019)\end{array}$ & $\begin{array}{r}0.0113^{* * *} \\
(0.0024)\end{array}$ & $\begin{array}{r}0.0092 * * * \\
(0.0016)\end{array}$ & $\begin{array}{r}0.0094 * * * \\
(0.0017)\end{array}$ & $\begin{array}{r}0.0084^{* * *} \\
(0.0017)\end{array}$ & $\begin{array}{r}0.0074 * * * \\
(0.0017)\end{array}$ & $\begin{array}{r}0.0060 * * * \\
(0.0017)\end{array}$ & $\begin{array}{r}0.0210^{* * *} \\
(0.0038)\end{array}$ \\
\hline Tech X CNC Score $\left(\beta_{2}\right)$ & $\begin{array}{r}-0.0003 \\
(0.0008)\end{array}$ & $\begin{array}{r}0.0031^{* *} \\
(0.0011)\end{array}$ & $\begin{array}{r}0.0038 * * * \\
(0.0009)\end{array}$ & $\begin{array}{r}0.0044 * * * \\
(0.0012)\end{array}$ & $\begin{array}{r}0.0049 * * * \\
(0.0009)\end{array}$ & $\begin{array}{r}0.0056^{* * *} \\
(0.0009)\end{array}$ & $\begin{array}{r}0.0044 * * * \\
(0.0008)\end{array}$ & $\begin{array}{r}0.0051^{* * *} \\
(0.0007)\end{array}$ & $\begin{array}{r}0.0148^{* * *} \\
(0.0027)\end{array}$ \\
\hline $\begin{array}{l}\text { High-initial-wage X } \\
\text { CNC Score }\left(\beta_{3}\right)\end{array}$ & $\begin{array}{r}0.0002 \\
(0.0007)\end{array}$ & $\begin{array}{r}-0.0047 * * * \\
(0.0015)\end{array}$ & $\begin{array}{r}-0.0059 * * \\
(0.0022)\end{array}$ & $\begin{array}{r}-0.0044 * * * \\
(0.0013)\end{array}$ & $\begin{array}{r}-0.0043^{* * *} \\
(0.0013)\end{array}$ & $\begin{array}{r}-0.0041^{* * *} \\
(0.0010)\end{array}$ & $\begin{array}{r}-0.0040 * * * \\
(0.0008)\end{array}$ & $\begin{array}{r}-0.0036 * * * \\
(0.0007)\end{array}$ & $\begin{array}{r}-0.0074^{* *} \\
(0.0032)\end{array}$ \\
\hline $\begin{array}{l}\text { \# of observations } \\
\text { R-squared }\end{array}$ & $\begin{array}{r}12984300 \\
0.2108 \\
\end{array}$ & $\begin{array}{r}12425700 \\
0.1741 \\
\end{array}$ & $\begin{array}{r}11971100 \\
0.1732 \\
\end{array}$ & $\begin{array}{r}11602500 \\
0.1768 \\
\end{array}$ & $\begin{array}{r}11334900 \\
0.1817 \\
\end{array}$ & $\begin{array}{r}11127400 \\
0.1836 \\
\end{array}$ & $\begin{array}{r}10861700 \\
0.1831 \\
\end{array}$ & $\begin{array}{r}10661700 \\
0.1885 \\
\end{array}$ & $\begin{array}{r}6492100 \\
0.2113 \\
\end{array}$ \\
\hline $\begin{array}{l}\text { High vs Low Wage in } \\
\text { Tech industry }\left(\beta_{1}+\beta_{3}\right) \\
\text { p value }\end{array}$ & $\begin{array}{r}0.00506^{* * *} \\
3.13 \mathrm{e}-06\end{array}$ & $\begin{array}{r}0.00519 * * * \\
1.18 \mathrm{e}-06\end{array}$ & $\begin{array}{r}0.00535^{* * *} \\
3.73 \mathrm{e}-08\end{array}$ & $\begin{array}{r}0.00479 * * * \\
3.26 \mathrm{e}-06\end{array}$ & $\begin{array}{r}0.00515^{* * *} \\
0.000248\end{array}$ & $\begin{array}{r}0.00432 * * * \\
0.00177\end{array}$ & $\begin{array}{r}0.00343^{* *} \\
0.0141\end{array}$ & $\begin{array}{r}0.00245^{*} \\
0.0797\end{array}$ & $\begin{array}{r}0.0136^{* * * *} \\
1.02 \mathrm{e}-05\end{array}$ \\
\hline $\begin{array}{l}\text { Tech vs Non-Tech in } \\
\text { High-initial-wage jobs } \\
\left(\beta_{1}+\beta_{2}\right) \\
\text { p value }\end{array}$ & $\begin{array}{r}0.0045 * * * \\
3.76 \mathrm{e}-05 \\
\end{array}$ & $\begin{array}{r}0.0129 * * * \\
6.75 \mathrm{e}-10 \\
\end{array}$ & $\begin{array}{r}0.0151^{* * *} \\
6.14 \mathrm{e}-07 \\
\end{array}$ & $\begin{array}{r}0.0136 * * * \\
9.60 \mathrm{e}-10 \\
\end{array}$ & $\begin{array}{r}0.0143 * * * \\
5.07 \mathrm{e}-11 \\
\end{array}$ & $\begin{array}{r}0.0140 * * * \\
4.97 \mathrm{e}-10 \\
\end{array}$ & $\begin{array}{r}0.0119 * * * \\
7.64 \mathrm{e}-08 \\
\end{array}$ & $\begin{array}{r}0.0111^{* * *} \\
4.89 \mathrm{e}-07 \\
\end{array}$ & $\begin{array}{r}0.0358 * * * \\
1.36 \mathrm{e}-10 \\
\end{array}$ \\
\hline Fixed Effects & \multicolumn{9}{|c|}{ State + [Industry - Starting Year - Firm Size - Starting Wage - Starting Age - Sex] } \\
\hline Sample & \multicolumn{8}{|c|}{ All jobs that are not right censored by the quarter } & $\begin{array}{l}\text { Spell started } \\
2000 \text { or } \\
\text { earlier }\end{array}$ \\
\hline
\end{tabular}


Table 4. Effect of CNC on Wage across Job Tenure: Sub-Samples by Industry and Initial Wage

This table reports the differential treatment effect of CNC enforceability on wage throughout job tenure, across sub-samples by industry (high-tech jobs vs nontech jobs) and initial wage (high-initial-wage jobs vs low-initial-wage jobs). High-initial-wage jobs are jobs whose starting wage is above the 98th percentile in the distribution of starting wages of jobs that have the same three-digit NAICS codes. The dependent variables are the log of quarterly wages at $4^{\text {th }}, \ldots, 32^{\text {nd }}$ quarter of the job spell. CNC Score is measured as the 2009 CNC enforcement index scores. All standard errors are clustered by state. ***, **, and * denote significance levels of $1 \%, 5 \%$, and $10 \%$, respectively.

\begin{tabular}{|c|c|c|c|c|c|c|c|c|}
\hline Dependent Variable: & (1) & (2) & (3) & (4) & (5) & (6) & (7) & (8) \\
\hline & & & & & & & & \\
\hline $\begin{array}{l}\text { Tech X High-initial- } \\
\text { wage X CNC Score }\left(\beta_{1}\right)\end{array}$ & $\begin{array}{r}-0.0098 * * * \\
(0.0030)\end{array}$ & $\begin{array}{r}-0.0085^{* *} \\
(0.0040)\end{array}$ & $\begin{array}{r}-0.0123 * * * \\
(0.0040)\end{array}$ & $\begin{array}{r}-0.0130 * * * \\
(0.0037)\end{array}$ & $\begin{array}{r}-0.0146 * * * \\
(0.0031)\end{array}$ & $\begin{array}{r}-0.0145^{* * *} \\
(0.0034)\end{array}$ & $\begin{array}{r}-0.0159 * * * \\
(0.0028)\end{array}$ & $\begin{array}{r}-0.0185 * * * \\
(0.0043)\end{array}$ \\
\hline Tech X CNC Score $\left(\beta_{2}\right)$ & $\begin{array}{r}-0.0055^{* * *} \\
(0.0006)\end{array}$ & $\begin{array}{r}-0.0064^{* * *} \\
(0.0006)\end{array}$ & $\begin{array}{r}-0.0065 * * * \\
(0.0007)\end{array}$ & $\begin{array}{r}-0.0066^{* * *} \\
(0.0008)\end{array}$ & $\begin{array}{r}-0.0057 * * * \\
(0.0008)\end{array}$ & $\begin{array}{r}-0.0051^{* * *} \\
(0.0009)\end{array}$ & $\begin{array}{r}-0.0057 * * * \\
(0.0012)\end{array}$ & $\begin{array}{r}-0.0052 * * * \\
(0.0015)\end{array}$ \\
\hline $\begin{array}{l}\text { High-initial-wage } X \\
\text { CNC Score }\left(\beta_{3}\right)\end{array}$ & $\begin{array}{r}-0.0215^{* * *} \\
(0.0039)\end{array}$ & $\begin{array}{r}-0.0201 * * * \\
(0.0039)\end{array}$ & $\begin{array}{r}-0.0196 * * * \\
(0.0062)\end{array}$ & $\begin{array}{r}-0.0213^{* * *} \\
(0.0068)\end{array}$ & $\begin{array}{r}-0.0245^{* * *} \\
(0.0084)\end{array}$ & $\begin{array}{r}-0.0205^{* *} \\
(0.0077)\end{array}$ & $\begin{array}{r}-0.0246 * * * \\
(0.0084)\end{array}$ & $\begin{array}{r}-0.0308 * * * \\
(0.0100)\end{array}$ \\
\hline $\begin{array}{l}\text { \# of observations } \\
\text { R-squared }\end{array}$ & $\begin{array}{r}10904200 \\
0.6726\end{array}$ & $\begin{array}{r}7397200 \\
0.6090\end{array}$ & $\begin{array}{r}5399500 \\
0.5764\end{array}$ & $\begin{array}{r}4048400 \\
0.5571\end{array}$ & $\begin{array}{r}3145300 \\
0.5430\end{array}$ & $\begin{array}{r}2478900 \\
0.5324\end{array}$ & $\begin{array}{r}1858400 \\
0.5238\end{array}$ & $\begin{array}{r}1412600 \\
0.5115\end{array}$ \\
\hline $\begin{array}{l}\text { High vs Low Wage in } \\
\text { Tech industry }\left(\beta_{1}+\beta_{3}\right) \\
\text { p value }\end{array}$ & $\begin{array}{r}-0.0313^{* * *} \\
1.52 \mathrm{e}-05\end{array}$ & $\begin{array}{r}-0.0286 * * * \\
0.000279\end{array}$ & $\begin{array}{r}-0.0320 * * * \\
0.00124\end{array}$ & $\begin{array}{r}-0.0343^{* * *} \\
0.00104\end{array}$ & $\begin{array}{r}-0.0390 * * * \\
7.45 \mathrm{e}-05\end{array}$ & $\begin{array}{r}-0.0350 * * * \\
0.000110\end{array}$ & $\begin{array}{r}-0.0405^{* * * *} \\
5.48 \mathrm{e}-06\end{array}$ & $\begin{array}{r}-0.0493 * * * \\
5.37 \mathrm{e}-07\end{array}$ \\
\hline $\begin{array}{l}\text { Tech vs Non-Tech in } \\
\text { High-initial-wage jobs } \\
\left(\beta_{1}+\beta_{2}\right) \\
\text { p value }\end{array}$ & $-0.0152 * * *$ & $-0.0149 * * *$ & $-0.0188 * * *$ & $-0.0196 * * *$ & $-0.0203^{* * *}$ & $-0.0196 * * *$ & $-0.0216 * * *$ & $-0.0237 * * *$ \\
\hline Fixed Effects & \multicolumn{8}{|c|}{ State + [Industry - Starting Year - Firm Size - Starting Wage - Starting Age - Sex] } \\
\hline Sample & \multicolumn{8}{|c|}{ All continuing jobs in the quarter } \\
\hline
\end{tabular}




\section{Table 5. Effect of CNC on High-Tech Workers' Cumulative Wage and Wage Growth across Job Tenure}

This table reports the differential treatment effect of CNC enforceability on cumulative wage and on wage growth from initial wage, across job tenure, by industry (high-tech jobs vs. non-tech jobs). The dependent variables are the log of cumulative wage at $4^{\text {th }}, 8^{\text {th }}, \ldots, 32^{\text {nd }}$ quarter of the job spell for Panel A, and the difference between the log of quarterly wages at $4^{\text {th }}, 8^{\text {th }}, \ldots, 32^{\text {nd }}$ quarter of the job spell and the log of initial wage for Panel B. CNC Score is measured as the 2009 CNC enforcement index scores. All standard errors are clustered by state. ***, **, and * denote significance levels of $1 \%$, 5\%, and $10 \%$, respectively.

\section{Panel A. Cumulative Wage}

\begin{tabular}{|c|c|c|c|c|c|c|c|c|}
\hline $\begin{array}{l}\text { Dependent Variable: } \\
\text { Log of cumulative wage at }\end{array}$ & $\begin{array}{c}\text { (1) } \\
\text { 4th qr }\end{array}$ & $\begin{array}{c}(2) \\
\text { 8th qr }\end{array}$ & $\begin{array}{c}\text { (3) } \\
\text { 12th qr }\end{array}$ & $\begin{array}{c}\text { (4) } \\
\text { 16th qr }\end{array}$ & $\begin{array}{c}\text { (5) } \\
\text { 20th qr }\end{array}$ & $\begin{array}{c}(6) \\
\text { 24th qr }\end{array}$ & $\begin{array}{c}(7) \\
\text { 28th qr }\end{array}$ & $\begin{array}{c}\text { (8) } \\
\text { 32th qr }\end{array}$ \\
\hline Tech X CNC Score & $\begin{array}{r}-0.0060 * * * \\
(0.0008)\end{array}$ & $\begin{array}{r}-0.0072 * * * \\
(0.0005)\end{array}$ & $\begin{array}{r}-0.0077^{* * *} \\
(0.0006)\end{array}$ & $\begin{array}{r}-0.0079 * * * \\
(0.0006)\end{array}$ & $\begin{array}{r}-0.0080 * * * \\
(0.0007)\end{array}$ & $\begin{array}{r}-0.0084^{* * *} \\
(0.0009)\end{array}$ & $\begin{array}{r}-0.0081^{* * *} \\
(0.0012)\end{array}$ & $\begin{array}{r}-0.0094^{* * *} \\
(0.0015)\end{array}$ \\
\hline $\begin{array}{l}\text { \# of observations } \\
\text { R-squared }\end{array}$ & $\begin{array}{r}10904000 \\
0.5902\end{array}$ & $\begin{array}{r}7397000 \\
0.6437 \\
\end{array}$ & $\begin{array}{r}5399000 \\
0.6708\end{array}$ & $\begin{array}{r}4048000 \\
0.6838\end{array}$ & $\begin{array}{r}3145000 \\
0.6891 \\
\end{array}$ & $\begin{array}{r}2479000 \\
0.6894\end{array}$ & $\begin{array}{r}1858000 \\
0.6887\end{array}$ & $\begin{array}{r}1413000 \\
0.6814\end{array}$ \\
\hline Fixed Effects & \multicolumn{8}{|c|}{ State + [Industry - Starting Year - Firm Size - Starting Wage - Starting Age - Sex] } \\
\hline Sample & \multicolumn{8}{|c|}{ All continuing jobs in the quarter } \\
\hline
\end{tabular}

\section{Panel B. Wage Growth}

\begin{tabular}{|c|c|c|c|c|c|c|c|c|}
\hline Dependent Variable: & (1) & (2) & (3) & (4) & (5) & (6) & (7) & (8) \\
\hline $\begin{array}{l}\text { Log of wage at xth quarter } \\
\text { - Log of initial wage }\end{array}$ & 4th qr & 8th qr & 12th qr & 16th qr & 20th qr & 24th qr & 28th qr & 32th qr \\
\hline Tech X CNC Score & $\begin{array}{r}-0.0054 * * * \\
(0.0005)\end{array}$ & $\begin{array}{r}-0.0063^{* * *} \\
(0.0006)\end{array}$ & $\begin{array}{r}-0.0065^{* * *} \\
(0.0007)\end{array}$ & $\begin{array}{r}-0.0066 * * * \\
(0.0008)\end{array}$ & $\begin{array}{r}-0.0057^{* * *} \\
(0.0008)\end{array}$ & $\begin{array}{r}-0.0050 * * * \\
(0.0009)\end{array}$ & $\begin{array}{r}-0.0057 * * * \\
(0.0012)\end{array}$ & $\begin{array}{r}-0.0056 * * * \\
(0.0015)\end{array}$ \\
\hline \# of observations & 10904000 & 7397000 & 5399000 & 4048000 & 3145000 & 2479000 & 1858000 & 1413000 \\
\hline R-squared & 0.1455 & 0.1779 & 0.2047 & 0.2281 & 0.2504 & 0.2721 & 0.2946 & 0.3129 \\
\hline Fixed Effects & \multicolumn{8}{|c|}{ State + [Industry - Starting Year - Firm Size - Starting Wage - Starting Age - Sex] } \\
\hline Sample & \multicolumn{8}{|c|}{ All continuing jobs in the quarter } \\
\hline
\end{tabular}


Table 6. Effect of CNC on Cumulative Wages and Wage Growth over Job Tenure: Sub-Samples by Industry and Initial Wage

This table reports the differential treatment effect of CNC enforceability on cumulative wage and on wage growth from initial wage throughout job tenure, across sub-samples by industry (high-tech jobs vs non-tech jobs) and initial wage (high-initial-wage jobs vs low-initial-wage jobs). High-initial-wage jobs are jobs whose starting wage is above the 98th percentile in the distribution of starting wages of jobs that have the same three-digit NAICS codes. The dependent variables are the log of cumulative wage at $4^{\text {th }}, 12^{\text {th }}, 20^{\text {th }}, 28^{\text {th }}$ quarter of the job spell for columns $(1) \sim(4)$, and the difference between the log of quarterly wages at $4^{\text {th }}, 12^{\text {th }}, 20^{\text {th }}, 28^{\text {th }}$ quarter of the job spell and the log of initial wage for columns (5) (8). CNC Score is measured as the 2009 CNC enforcement index scores. All standard errors are clustered by state. ***, **, and * denote significance levels of $1 \%, 5 \%$, and $10 \%$, respectively.

\begin{tabular}{|c|c|c|c|c|c|c|c|c|}
\hline \multirow[t]{2}{*}{ Dependent Variable } & \multicolumn{4}{|c|}{ Log of cumulative wage at } & \multicolumn{4}{|c|}{ Log of wage at xth quarter - Log of initial wage } \\
\hline & $\begin{array}{c}\text { (1) } \\
\text { 4th quarter }\end{array}$ & $\begin{array}{c}\text { (2) } \\
\text { 12th quarter }\end{array}$ & $\begin{array}{c}\text { (3) } \\
\text { 20th quarter }\end{array}$ & $\begin{array}{c}\text { (4) } \\
\text { 28th quarter }\end{array}$ & $\begin{array}{c}\text { (5) } \\
\text { 4th quarter }\end{array}$ & $\begin{array}{c}\text { (6) } \\
\text { 12th quarter }\end{array}$ & $\begin{array}{c}\text { (7) } \\
\text { 20th quarter }\end{array}$ & $\begin{array}{c}\text { (8) } \\
\text { 28th quarter }\end{array}$ \\
\hline $\begin{array}{l}\text { Tech X High-initial-wage } \\
\text { X CNC Score }\left(\beta_{1}\right)\end{array}$ & $\begin{array}{r}-0.0112^{* * *} \\
(0.0029)\end{array}$ & $\begin{array}{r}-0.0095^{* * *} \\
(0.0034)\end{array}$ & $\begin{array}{r}-0.0192 * * * \\
(0.0031)\end{array}$ & $\begin{array}{r}-0.0182 * * * \\
(0.0040)\end{array}$ & $\begin{array}{r}-0.0027 \\
(0.0026)\end{array}$ & $\begin{array}{r}-0.0084^{* * *} \\
(0.0030)\end{array}$ & $\begin{array}{r}-0.0087 * * \\
(0.0038)\end{array}$ & $\begin{array}{r}-0.0130 * * \\
(0.0052)\end{array}$ \\
\hline Tech X CNC Score $\left(\beta_{2}\right)$ & $\begin{array}{r}-0.0057 * * * \\
(0.0008)\end{array}$ & $\begin{array}{r}-0.0074 * * * \\
(0.0006)\end{array}$ & $\begin{array}{r}-0.0076^{* * * *} \\
(0.0007)\end{array}$ & $\begin{array}{r}-0.0077 * * * \\
(0.0012)\end{array}$ & $\begin{array}{r}-0.0054^{* * * *} \\
(0.0005)\end{array}$ & $\begin{array}{r}-0.0063^{* * * *} \\
(0.0008)\end{array}$ & $\begin{array}{r}-0.0055^{* * * *} \\
(0.0008)\end{array}$ & $\begin{array}{r}-0.0054^{* * * *} \\
(0.0012)\end{array}$ \\
\hline $\begin{array}{l}\text { High-initial-wage X CNC } \\
\text { Score }\left(\beta_{3}\right)\end{array}$ & $\begin{array}{r}-0.0186 * * * \\
(0.0043)\end{array}$ & $\begin{array}{r}-0.0224 * * * \\
(0.0063)\end{array}$ & $\begin{array}{r}-0.0240 * * * \\
(0.0078)\end{array}$ & $\begin{array}{r}-0.0257 * * * \\
(0.0074)\end{array}$ & $\begin{array}{r}-0.0136^{* * *} \\
(0.0015)\end{array}$ & $\begin{array}{r}-0.0094 * * * \\
(0.0023)\end{array}$ & $\begin{array}{r}-0.0125^{* * *} \\
(0.0044)\end{array}$ & $\begin{array}{r}-0.0122 * * \\
(0.0047)\end{array}$ \\
\hline $\begin{array}{l}\text { \# of observations } \\
\text { R-squared }\end{array}$ & $\begin{array}{r}10904000 \\
0.5902 \\
\end{array}$ & $\begin{array}{r}5399000 \\
0.6709 \\
\end{array}$ & $\begin{array}{r}3145000 \\
0.6892 \\
\end{array}$ & $\begin{array}{r}1858000 \\
0.6889 \\
\end{array}$ & $\begin{array}{r}10904000 \\
0.1455 \\
\end{array}$ & $\begin{array}{r}5399000 \\
0.2047 \\
\end{array}$ & $\begin{array}{r}3145000 \\
0.2504 \\
\end{array}$ & $\begin{array}{r}1858000 \\
0.2947 \\
\end{array}$ \\
\hline $\begin{array}{l}\text { High vs Low Wage in Tech } \\
\text { industry }\left(\beta_{1}+\beta_{3}\right) \\
\text { p value }\end{array}$ & $\begin{array}{r}-0.0298 * * * \\
2.13 e-05\end{array}$ & $\begin{array}{r}-0.0319 * * * \\
0.000727\end{array}$ & $\begin{array}{r}-0.0432 * * * \\
9.91 \mathrm{e}-05\end{array}$ & $\begin{array}{r}-0.0439 * * * \\
0.000357\end{array}$ & $\begin{array}{r}-0.0163^{* * *} \\
7.73 \mathrm{e}-06\end{array}$ & $\begin{array}{r}-0.0178 * * * \\
1.25 \mathrm{e}-05\end{array}$ & $\begin{array}{r}-0.0212 * * * \\
2.21 \mathrm{e}-10\end{array}$ & $\begin{array}{r}-0.0252 * * * \\
0\end{array}$ \\
\hline $\begin{array}{l}\text { Tech vs Non-Tech in High- } \\
\text { initial-wage jobs }\left(\beta_{1}+\beta_{2}\right) \\
\text { p value }\end{array}$ & $\begin{array}{r}-0.0169 * * * \\
3.52 \mathrm{e}-07\end{array}$ & $\begin{array}{r}-0.0169 * * * \\
1.21 \mathrm{e}-05\end{array}$ & $\begin{array}{r}-0.0268 * * * \\
3.23 \mathrm{e}-09\end{array}$ & $\begin{array}{r}-0.0259 * * * \\
4.75 \mathrm{e}-07\end{array}$ & $\begin{array}{r}-0.00813^{* * *} \\
0.00369\end{array}$ & $\begin{array}{r}-0.0146 * * * \\
1.80 \mathrm{e}-05\end{array}$ & $\begin{array}{r}-0.0142^{* * *} \\
0.00142\end{array}$ & $\begin{array}{r}-0.0184^{* * *} \\
0.00197\end{array}$ \\
\hline Fixed Effects & & State + & ustry - Startin & Year - Firm Si & - Starting Wa & - Starting Ag & Sex] & \\
\hline Sample & & & & continuing jo & in the quarter & & & \\
\hline
\end{tabular}




\section{Table 7. Effect of CNC on High-Tech Workers’ Career Outcomes across Employment History}

This table reports the differential treatment effect of CNC enforceability on cumulative number of jobs taken across workers' employment history in Panel A, and on cumulative earnings across workers' employment history in Panel B, by industry (high-tech jobs vs. non-tech jobs) of the worker's first job. The dependent variables are the log of cumulative number of jobs taken at $4^{\text {th }}, \ldots, 32^{\text {nd }}$ quarter of the workers' employment history in Panel $A$, and the log of cumulative earnings at $4^{\text {th }}, \ldots, 32^{\text {nd }}$ quarter of the workers' employment history in Panel B. The high-tech job dummy variable is that of the first job of the worker. CNC Score is measured as the 2009 CNC enforcement index scores of the state in which the first job of the worker is geographically located in. The joblevel fixed effects controls for the job characteristics of the first job of the worker. All standard errors are clustered by state. ***, **, and * denote significance levels of $1 \%, 5 \%$, and $10 \%$, respectively.

\section{Panel A. Number of Jobs across Employment History}

\begin{tabular}{|c|c|c|c|c|c|c|c|c|}
\hline Dependent Variable: & $(1)$ & $(2)$ & (3) & $(4)$ & (5) & (6) & (7) & (8) \\
\hline Log of cumulative number of jobs at & 4th qr & 8th qr & 12th qr & 16th qr & 20th qr & 24th qr & 28th qr & 32th qr \\
\hline Tech X CNC Score & $\begin{array}{r}-0.0085 \\
(0.0057)\end{array}$ & $\begin{array}{c}-0.0121 * \\
(0.0062)\end{array}$ & $\begin{array}{r}-0.0142^{* *} \\
(0.0065)\end{array}$ & $\begin{array}{c}-0.0136 * \\
(0.0073)\end{array}$ & $\begin{array}{r}-0.0156^{* *} \\
(0.0076)\end{array}$ & $\begin{array}{r}-0.0185^{* *} \\
(0.0074)\end{array}$ & $\begin{array}{r}-0.0197 * * \\
(0.0080)\end{array}$ & $\begin{array}{r}-0.0215^{* *} \\
(0.0079)\end{array}$ \\
\hline \# of observations & 7517000 & 6389000 & 5594000 & 4973000 & 4485000 & 4057000 & 3671000 & 3229000 \\
\hline R-squared & 0.3325 & 0.2892 & 0.2626 & 0.2477 & 0.2368 & 0.2330 & 0.2332 & 0.2352 \\
\hline Fixed Effects & \multicolumn{8}{|c|}{ State + [Industry - Starting Year - Firm Size - Starting Wage - Starting Age - Sex] } \\
\hline Sample & \multicolumn{8}{|c|}{ All employed workers in the quarter } \\
\hline
\end{tabular}

\section{Panel B. Cumulative Earnings across Employment History}

\begin{tabular}{|c|c|c|c|c|c|c|c|c|}
\hline Dependent Variable: & $(1)$ & $(2)$ & (3) & (4) & (5) & (6) & (7) & (8) \\
\hline Log of cumulative earnings at & 4th qr & 8th qr & 12th qr & 16th qr & 20th qr & 24th qr & 28th qr & 32th qr \\
\hline Tech X CNC Score & $\begin{array}{r}-0.0112 * * * \\
(0.0028)\end{array}$ & $\begin{array}{r}-0.0118 * * * \\
(0.0025)\end{array}$ & $\begin{array}{r}-0.0123 * * * \\
(0.0022)\end{array}$ & $\begin{array}{r}-0.0128 * * * \\
(0.0020)\end{array}$ & $\begin{array}{r}-0.0126 * * * \\
(0.0017)\end{array}$ & $\begin{array}{r}-0.0125 * * * \\
(0.0015)\end{array}$ & $\begin{array}{r}-0.0121 * * * \\
(0.0012)\end{array}$ & $\begin{array}{r}-0.0115^{* * * *} \\
(0.0012)\end{array}$ \\
\hline \# of observations & 7517000 & 6389000 & 5594000 & 4973000 & 4485000 & 4057000 & 3671000 & 3229000 \\
\hline R-squared & 0.6245 & 0.6121 & 0.5951 & 0.5778 & 0.5603 & 0.5448 & 0.5291 & 0.5143 \\
\hline Fixed Effects & \multicolumn{8}{|c|}{ State + [Industry - Starting Year - Firm Size - Starting Wage - Starting Age - Sex] } \\
\hline Sample & \multicolumn{8}{|c|}{ All employed workers in the quarter } \\
\hline
\end{tabular}




\section{Table 8. Effect of CNC on High-Tech Workers' Switching States or Industries}

This table reports the differential treatment effect of CNC enforceability on cumulative number of state switches in Panel A, on cumulative number of industry switches in Panel B, and on cumulative number of state-but-not-industry switches in Panel C, across workers' employment history, by industry (high-tech jobs vs. non-tech jobs) of the first job. The dependent variables are log (1+cumulative number of state switches) in Panel A, log (1+cumulative number of three-digit NAICS code switches) in Panel B, and $\log \left(1+\right.$ cumulative number of state-but-not-industry-switches) in Panel C, at $4^{\text {th }}, \ldots, 32^{\text {nd }}$ quarter of the workers' employment history. CNC Score is measured as the 2009 CNC enforcement index scores of the state in which the first job of the worker is geographically located in. The job-level fixed effects controls for the job characteristics of the first job of the worker. All standard errors are clustered by state. ***, **, and * denote significance levels of $1 \%, 5 \%$, and $10 \%$, respectively.

\begin{tabular}{|c|c|c|c|c|c|c|c|c|}
\hline Panel A. Switch States & (1) & (2) & (3) & (4) & (5) & (6) & (7) & (8) \\
\hline $\begin{array}{l}\text { Dependent Variable: Ln(1+cumulative \# } \\
\text { of state switch) at }\end{array}$ & 4th qr & 8th qr & 12th qr & 16th qr & 20th qr & 24th qr & 28th qr & 32th qr \\
\hline \multirow{2}{*}{ Tech X CNC Score } & $0.0003^{*}$ & $0.0008^{* * *}$ & $0.0012^{* * *}$ & $0.0014^{* * *}$ & $0.0012 * * *$ & $0.0013^{* * *}$ & $0.0013^{* * *}$ & $0.0013^{* *}$ \\
\hline & $(0.0001)$ & $(0.0003)$ & $(0.0003)$ & $(0.0004)$ & $(0.0003)$ & $(0.0004)$ & $(0.0005)$ & $(0.0006)$ \\
\hline R-squared & 0.0746 & 0.0774 & 0.0855 & 0.0926 & 0.0987 & 0.104 & 0.1085 & 0.1138 \\
\hline \multirow{2}{*}{$\begin{array}{l}\text { Panel B. Switch Industry } \\
\text { Dependent Variable: Ln(1+cumulative \# } \\
\text { of industry switch) at }\end{array}$} & (1) & (2) & (3) & (4) & (5) & (6) & (7) & (8) \\
\hline & 4th qr & 8th qr & 12th qr & 16th qr & 20th qr & 24th qr & 28th qr & 32th qr \\
\hline \multirow{2}{*}{ Tech X CNC Score } & $-0.0018 * * *$ & $-0.0044^{* * *}$ & $-0.0067 * * *$ & $-0.0094^{* * *}$ & $-0.0119 * * *$ & $-0.0135 * * *$ & $-0.0162 * * *$ & $-0.0186 * * *$ \\
\hline & $(0.0006)$ & $(0.0012)$ & $(0.0021)$ & $(0.0027)$ & $(0.0033)$ & $(0.0038)$ & $(0.0038)$ & $(0.0037)$ \\
\hline R-squared & 0.1305 & 0.1394 & 0.1502 & 0.158 & 0.1633 & 0.1674 & 0.1722 & 0.1749 \\
\hline \multirow{2}{*}{$\begin{array}{l}\text { Panel C. Switch State but not Industry } \\
\text { Dependent Variable: Ln( } 1+\text { cumulative \# } \\
\text { of state switch without industry switch }) \\
\text { at }\end{array}$} & (1) & $(2)$ & (3) & (4) & (5) & (6) & (7) & (8) \\
\hline & 4th qr & 8th qr & 12th qr & 16th qr & 20th qr & 24th qr & 28th qr & 32th qr \\
\hline \multirow{2}{*}{ Tech X CNC Score } & $0.0001^{* * *}$ & $0.0003^{* * *}$ & $0.0006^{* * *}$ & $0.0007 * * *$ & $0.0007^{* * *}$ & $0.0008^{* * *}$ & $0.0008^{* * *}$ & $0.0009 * * *$ \\
\hline & $(0)$ & $(0.0001)$ & $(0.0001)$ & $(0.0001)$ & $(0.0002)$ & $(0.0002)$ & $(0.0002)$ & $(0.0003)$ \\
\hline R-squared & 0.043 & 0.0525 & 0.0611 & 0.0685 & 0.074 & 0.0779 & 0.0814 & 0.0858 \\
\hline \# of observations & 7517000 & 6389000 & 5594000 & 4973000 & 4485000 & 4057000 & 3671000 & 3229000 \\
\hline Fixed Effects & \multicolumn{8}{|c|}{ State + [Industry - Starting Year - Firm Size - Starting Wage - Starting Age - Sex] } \\
\hline Sample & \multicolumn{8}{|c|}{ All employed workers in the quarter } \\
\hline
\end{tabular}




\section{Theory Appendix}

We model wage setting and employment choice (stay or move to another firm) for an incumbent worker. The relationship value (or additional firm value) generated by the worker is $\theta$. At the beginning of the period the worker gets a single wage draw $\left(W_{0}\right)$ from a uniform $[0,1+\mu]$ distribution.

Worker's decision rule is as follows: ${ }^{24}$

- If $W_{0}>\theta$ : Exit the firm and take outside offer

- If $W_{0} \leq \theta$ : Negotiate with the firm

The negotiated wage if the worker stays in the firm is given by:

$$
\mathrm{W} \text { (if stay) }=\alpha \theta+(1-\alpha)(\text { Outside option })=\alpha \theta+(1-\alpha)\left(\mathrm{W}_{0}\right)
$$

where $\alpha$ reflects bargaining power of the workers, so that when $\alpha=1$, the workers get paid the full value of the relationship. (We discuss the effect of noncompete on $\alpha$ below.) Then probability of exit is:

$\mathrm{P}[$ Exit $]=P\left[W_{0}>\theta\right]=1-\frac{\theta}{1+\mu}$

Expected wages (which correspond to our regressions estimates, assuming independent distributions and wage draws over time and across workers) are given by: ${ }^{25}$

$$
\begin{aligned}
& \mathrm{E}[\mathrm{W} \mid \text { Stay }]=\mathrm{E}\left[\mathrm{W} \mid \mathrm{W}_{0}<\theta\right]=\alpha \theta+(1-\alpha)\left(\mathrm{E}\left[\mathrm{W}_{0} \mid \mathrm{W}_{0}<\theta\right)=\alpha \theta+(1-\alpha) \frac{\theta}{2}=\frac{(1+\alpha) \theta}{2}\right. \\
& \begin{aligned}
& \mathrm{E}[\mathrm{W} \mid \text { exit }]=\left(\mathrm{E}\left[\mathrm{W}_{0} \mid \mathrm{W}_{0} \geq \theta\right)=\frac{(1+\mu) \theta}{2}\right. \\
& \mathrm{E}[\mathrm{W}]=\mathrm{P}[\text { Stay }] \mathrm{E}[\mathrm{W} \mid \text { Stay }]+\mathrm{P}[\text { Exit }] \mathrm{E}[\mathrm{W} \mid \text { Exit }] \\
&=P\left[W_{0}>\theta\right]\left(E\left[W_{0} \mid W_{0}>\theta\right]\right)+P\left[W_{0} \leq \theta\right]\left(\alpha \theta+(1-\alpha) E\left[W_{0} \mid W_{0}<\theta\right]\right) \\
& \quad=\frac{\theta}{1+\mu}\left(\frac{(1+\alpha) \theta}{2}\right)+\left(1-\frac{\theta}{1+\mu}\right)\left(\frac{(1+\mu)+\theta}{2}\right)=\left[\frac{1+\mu}{2}+\frac{\alpha \theta^{2}}{2(1+\mu)}\right]
\end{aligned}
\end{aligned}
$$

The expected wages and the probability of exiting the firm are illustrated in Figure TA1 below.

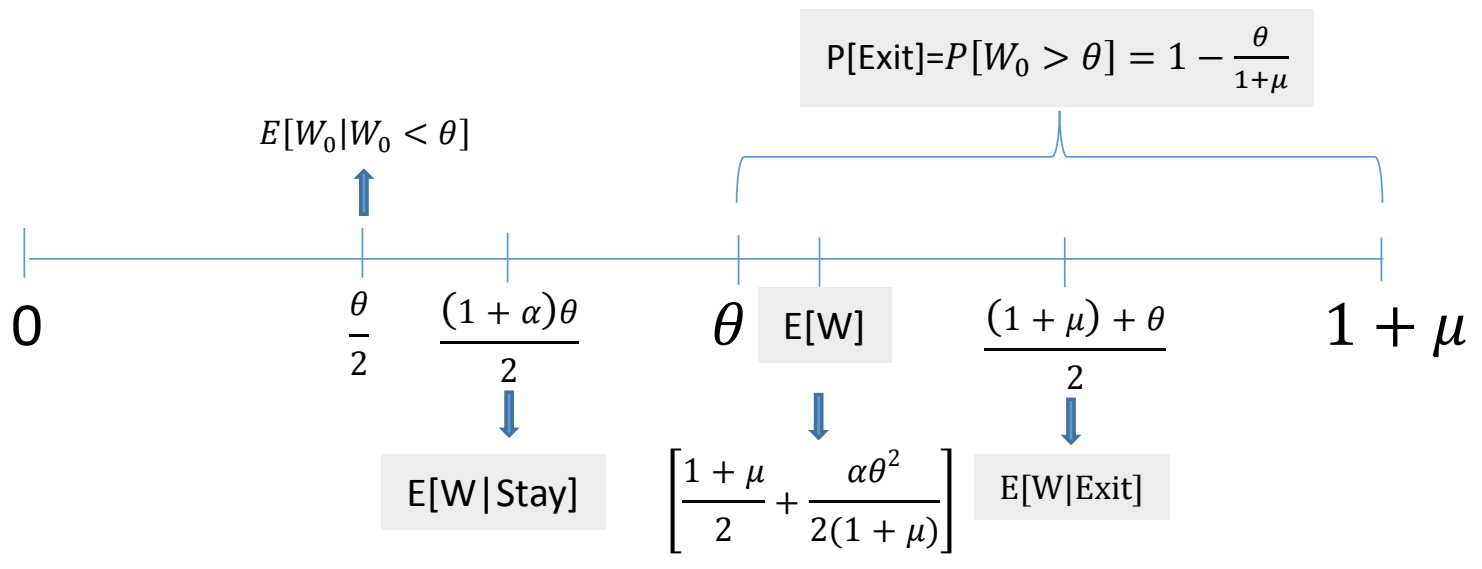

Figure TA1: Expected wages, and probability of exit

Assumptions about effects of non-compete enforceability: We make two fairly straightforward assumptions about the effects of non-compete enforceability $(\eta)$ : A1: Increase in enforceability leads to reduction in worker bargaining power, i.e., $\frac{d \alpha}{d \eta}<0$, and A2: The upper bound of outside wage distribution is decreasing

\footnotetext{
${ }^{24}$ To focus on CNC enforceability, our framework abstracts from other drivers of worker turnover including e.g., health shocks, spousal career shocks, or learning about match quality. This is innocuous so long as these are uncorrelated with degree of noncompete enforceability (or adequately controlled for in our empirical analysis). ${ }^{25}$ In particular, within job spell wage regressions correspond to E[Wage|stay] and worker career regressions correspond to the unconditional expected wage E[Wage].
} 
in enforceability, i.e., $\frac{d \mu}{d \eta}<0$. Assumption A1 is motivated by a widely discussed potential effect of noncompete covenants (e.g., Arnow-Richman 2006). Assumption A2 tractably captures two plausible effects of noncompete enforceability. First, the firms that can derive the highest value from the worker are likely to be close competitors who can exploit all of the worker's knowledge; so reduction in noncompete enforceability may induce some of the highest value outside bidders to make an offer. Second, while we assume for tractability that the worker seeks out one outside offer, in a more general case the worker may get multiple (say $\mathrm{N}$ ) bids so that the relevant outside option is the maximum of $\mathrm{N}$ bids. Increase in noncompete enforceability would likely decrease the number of firms willing to bid for the worker, which would decrease the expected maximum of the bids. ${ }^{26}$

We consider three alternative cases for the determination of the relationship value $\theta$.

\section{Case 1: Exogenous $\theta$}

In this case, by assumption the relationship-specific value does not vary with degree of noncompete enforcement. However, by assumptionsA1 and A2 above, the worker bargaining power and outside wage offer range varies leading to the following results:

Result 1: Probability of exit goes down with increase in noncompete enforcement.

Result 2a: $E[W \mid$ Stay $]$ (i.e., average wage conditional on staying in the initial job spell) goes down with increase in noncompete enforcement.

Result 2b: $E[W]$ (i.e., unconditional average wage) goes down with increase in noncompete enforcement.

Result 1 follows directly from assumption A2, as decrease in $\mu$ reduces the probability that the outside offer will exceed the relationship-specific value (see Equation 1). Similarly, reduction in worker bargaining power (assumption A1) leads immediately to Result 2a (see Equation 2). Result 2b, follows from the fact that in Equation (3) both E[W|Exit] and E[W|Stay] go down, and weight on the larger (E[W|Exit]) also down up (as P[Exit] goes up).

\section{Case 2: Endogenous $\boldsymbol{\theta}$, firm and individual investments matter for relationship value}

Suppose $\theta$ is endogenous and determined by firm investments $(k)$ and individual investments $(m)$, such that $\theta^{2}=\mathrm{a} k+\mathrm{b} m-\frac{\mathrm{c} k^{2}}{2}-\frac{\mathrm{d} m^{2}}{2}$

Firm and individual investments are made ex-ante, based on expectations. The firm's optimization problem is: $\max _{k} E[\Pi]=\max _{k}\{\mathrm{P}[$ stay $](\theta-\mathrm{E}[\mathrm{W} \mid$ stay $])-\mathrm{k}\}=\max _{k}\left\{\left(\frac{\theta}{1+\mu}\right)\left(\theta-\left(\frac{1+\alpha}{2}\right) \theta\right)-k\right\}$

$$
=\max _{k}\left(\left(\frac{1-\alpha}{2(1+\mu)}\right) \theta^{2}-k\right)
$$

The individual's optimization problem is: $\max _{m} E$ [Surplus $\left.]=\max _{m}\{\mathrm{E}[\mathrm{W}])-\mathrm{m}\right\}$

$$
=\max _{m}\left\{\left[\frac{1+\mu}{2}+\frac{\alpha \theta^{2}}{2(1+\mu)}\right]-m\right\}
$$

This yields optimal investment choices:

$k^{*}=\frac{1}{c}\left(\mathrm{a}-\frac{2(1+\mu)}{(1-\alpha)}\right) ; \quad m^{*}=\frac{1}{d}\left(\mathrm{~b}-\frac{2(1+\mu)}{\alpha}\right)$

Lemma 1a: Optimal investment $\left(k^{*}\right)$ is unambiguously increasing in degree of noncompete enforcement (as $\mu$ and $\alpha$ both decrease with noncompete enforcement).

Lemma $1 b$ : Optimal investment $\left(m^{*}\right)$ is decreasing in degree of noncompete enforcement so long as $\frac{d \alpha}{d \eta}<\frac{\alpha}{1+\mu} \frac{d \mu}{d \eta} \quad\left(\right.$ or $\left.\left|\frac{d \alpha}{d \eta}\right|>\frac{\alpha}{1+\mu}\left|\frac{d \mu}{d \eta}\right|\right)$.

\footnotetext{
${ }^{26}$ This can be seen analytically in the case where the underlying wage distribution is a Gumbel with location and scale parameters $\phi$ and $\sigma$; then expected maximum of $\mathrm{N}$ draws $=\phi+\sigma \log (\mathrm{N})$.
} 
For firms, the negative effects on both the bargaining and outside options increase investment incentives in high enforcement regimes. For individuals, the negative bargaining effect lowers investment incentive in high enforcement regimes, but the decrease in outside option increases the incentive to invest to increase relationship-specific value, so the net effect of an increase in CNC enforceability on individual investment is negative only if the magnitude of enforceability's effect on bargaining power is strong enough. Hereafter, to focus on the interesting case of varying implications for individual and firm investment we will assume

A3: $\frac{d \alpha}{d \eta}<\frac{\alpha}{1+\mu} \frac{d \mu}{d \eta}$ i.e., $\left|\frac{d \alpha}{d \eta}\right|>\frac{\alpha}{1+\mu}\left|\frac{d \mu}{d \eta}\right|$.

Solving out for optimal relationship capital yields:

$\theta^{*}=\left[\frac{a^{2}}{2 c}-\frac{2(1+\mu)^{2}}{c(1-\alpha)^{2}}+\frac{b^{2}}{2 d}-\frac{2(1+\mu)^{2}}{d \alpha^{2}}\right]^{0.5}$

We now consider two polar cases, to understand differences in outcomes depending on whether firm or individual investments matter for relationship-specific value.

\section{Case 2A: Only firm investments matter (i.e., $b=d=0$ )}

In equation 4, the third and fourth terms drop out, and we get the following results:

Result 3: Probability of exit is unambiguously decreasing in CNC enforceability.

This follows from the facts that optimal investment (Lemma 1a), and hence relationship capital level $\theta$ increases with enforceability (in equation $4, \mu$ and $\alpha$ decrease with increase in enforceability), and the upper bound $\mu$ drops (by assumption A1).

Result 4a: Effect of increased enforcement on $E[W \mid$ Stay $]$ (i.e., average wage conditional on staying in the initial job spell) is ambiguous.

This is because in equation 2, while $\theta$ increases with CNC enforcement, bargaining power $\alpha$ declines, so the net impact on the wages is unclear. Intuitively, the relationship-specific value is enhanced but workers' bargaining power may be lowered so much that they may not get any net benefit.

Result 4b: Effect of increased enforcement on $E[W]$ (i.e., unconditional average wage) is ambiguous.

This is because in equation 3, effect on both $\mathrm{E}[\mathrm{W} \mid \mathrm{Exit}]$ and $\mathrm{E}[\mathrm{W} \mid$ stay] is unclear, though weight on larger quantity (E[W|Exit]) (i.e., probability of exit) does go down (from Result 3 above).

\section{Case 2B: Only individual investments matter (i.e., $\mathbf{a}=\mathbf{c}=\mathbf{0}$ )}

In equation 4 the first and second terms drop out, and we get the following results:

Result 5: Effect of CNC enforceability on probability of exit is ambiguous; if $\frac{d \theta^{*}}{d \eta}>\frac{\theta^{*}}{1+\mu} \frac{d \mu}{d \eta}$

(i.e. , if $\left|\frac{d \theta^{*}}{d \eta}\right|<\frac{\theta^{*}}{1+\mu}\left|\frac{d \mu}{d \eta}\right|$ ) then probability of exit declines with enforceability.

This follows from the facts that while optimal investment (Lemma 1a), and hence relationship capital level $\theta$ decreases with enforceability (this is guaranteed by assumption A3, which makes $\frac{d \theta^{*}}{d \eta}<0$ ), the upper bound $\mu$ drops (by assumption A1). Thus the net effect depends on which shift is larger; only if the magnitude of the decline in optimal relationship value is small enough relative to magnitude of the decline in the upper bound will the probability of exit decline with enforceability.

Result 6a: $E[W \mid$ Stay] (i.e., average wage conditional on staying in the initial job spell) decreases with increase in enforceability.

This is because in equation 2, both $\theta$ and bargaining power $\alpha$ declines with enforceability. Intuitively, relationship value and bargaining power being lower means workers are worse off.

Result 6b: Effect of increased enforceability on $E[W]$ (i.e., unconditional average wage) is ambiguous in general, but if probability of exit is declining with enforceability, then $E[W]$ also declines with enforceability. 
This is because in equation 3, both $\mathrm{E}[\mathrm{W} \mid$ Exit $]$ and $\mathrm{E}[\mathrm{W} \mid$ Stay $]$ decrease with enforceability, but weight on larger quantity (E[W|Exit]) may increase (if P[Exit) goes up). If P[Exit) goes down (i.e., if shift in upper bound $\mu$ is modest relative to the shift in $\theta^{*}$ ), then then the ambiguity is resolved and $\mathrm{E}[\mathrm{W}]$ declines with enforceability.

\section{Endogeneity of enforcement choice by the firm}

The above analysis presumes that increase in enforceability results in decline of bargaining power (A1) and increase in upper bound of outside offers (A2). In principle however, firms could choose not to include CNC clauses even in high-enforceability regimes; this raises the question of whether it would be the case that excluding CNC clauses may be beneficial to the firm. The following lemmas address this.

Lemma 2a: In case 2A (where firm investments matter for relationship-specific value), it is in the firm's interest to fully exploit enforceability, i.e., firm surplus is greater with enforcing (and reducing bargaining power (A1) and outside offers (A2)) than without.

Lemma 2b: In case $2 B$ (where individual investments matter for relationship-specific value), sufficient conditions for the firm to fully exploit enforceability are that (i) probability of exit declines in enforceability, and (ii) $\frac{d \theta^{*}}{d \eta}>\frac{\theta^{*}}{1-\alpha} \frac{d \alpha}{d \eta}$ (i.e. . $\left|\frac{d \theta^{*}}{d \eta}\right|<\frac{\theta^{*}}{1-\alpha}\left|\frac{d \alpha}{d \eta}\right|$ )

Lemma 2a follows directly from taking a simple derivative of firm's optimal profit levels with respect to $\eta$ and verifying that higher enforcement $(\eta)$ in case $2 \mathrm{~A}$ leads to greater profits. Lemma $2 \mathrm{~b}$ follows form the fact that if probability of exit is lower, and if decline in bargaining power of the worker is steep enough, then the firm's share of the smaller pie (due to reduced worker investment) is larger with enforcement than without.

Note that in an incomplete information environment, A1 and A2 do not depend on formal inclusion of CNC clauses in employment contracts. In particular, if there are some firm types for whom Lemma 2a and/or 2b holds, and if outside bidders are unsure of the target worker's employer firm type, A2 would bind as bids would be more discouraged as enforceability increases. Similarly, if employees have incomplete information on whether CNC clauses are included in the contract (they may often be unaware of clauses in the contract e.g. Arnow-Richman 2006) or if they fear these could be introduced, that may be sufficient to reduce bargaining power, and make A1 bind as well. 
SUPPLEMENTAL ONLINE APPENDIX

Figure A1. Factor Analysis CNC Enforceability Index Scores for 2009

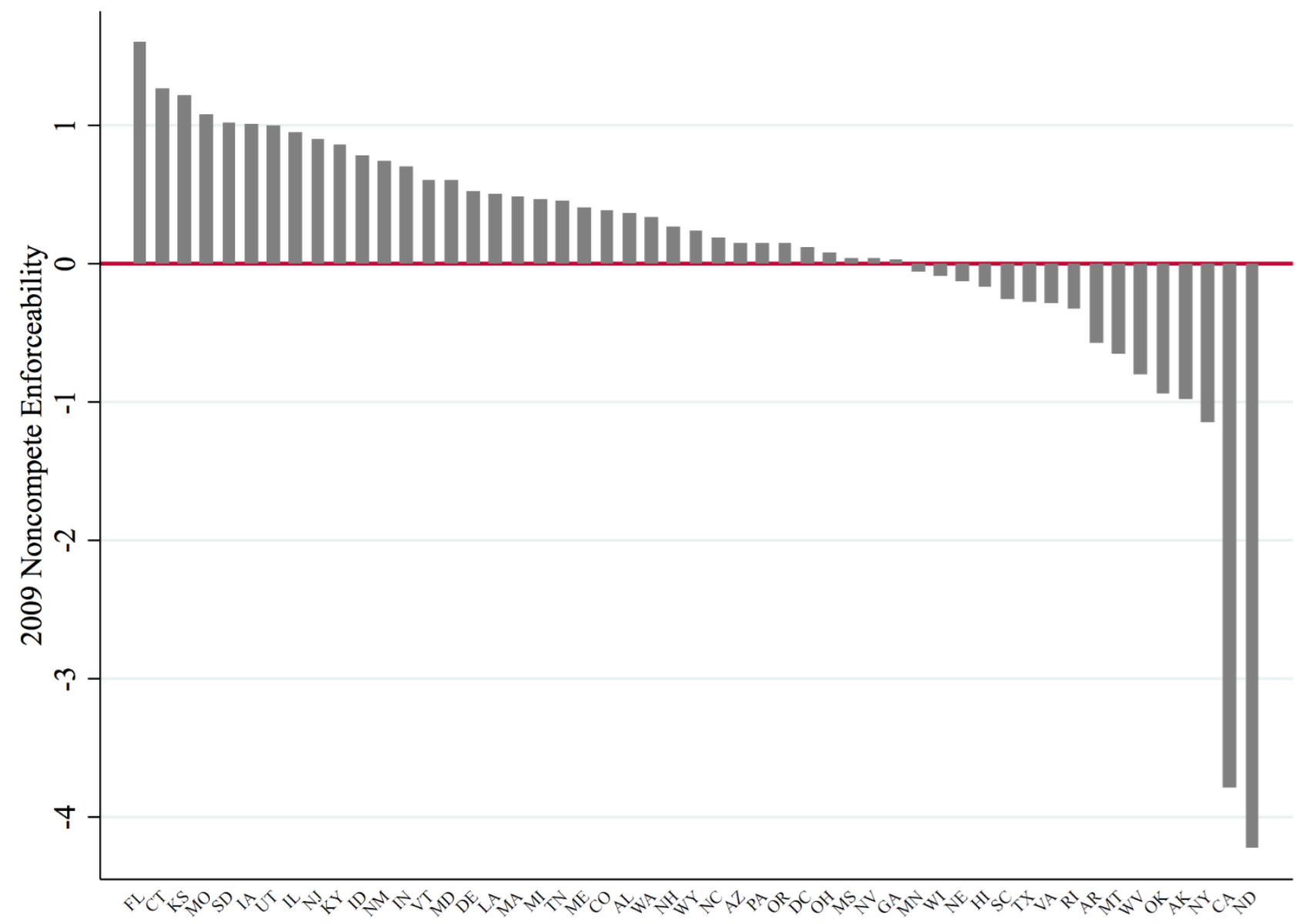




\section{Figure A2. Effect of CNC on High-Tech Workers’ Mobility}

This figure plots the coefficient estimates and the 95\% confidence intervals of the differential treatment effect of CNC enforceability on mobility, of high-tech jobs relative to non-tech jobs. Mobility is measured as the dummy variable for the spell surviving at $4^{\text {th }}, \ldots, 32^{\text {nd }}$ quarter of the job spell.

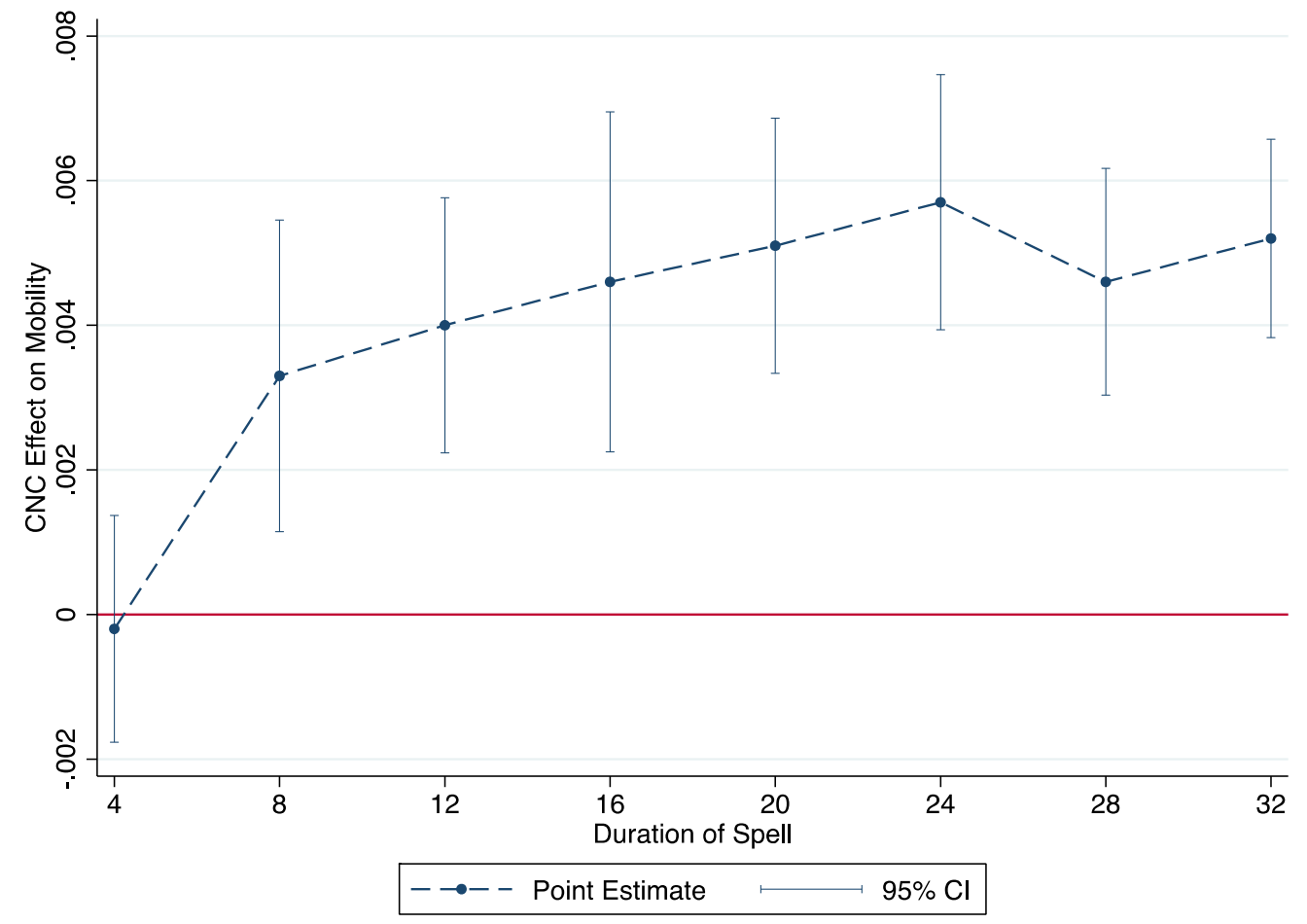




\section{Figure A3. Effect of CNC on High-Tech Workers’ Wage across Job Tenure}

This figure plots the coefficient estimates and the $95 \%$ confidence intervals of the differential treatment effect of CNC enforceability on wage, of high-tech jobs relative to non-tech jobs. Wage is the log of quarterly wage at $4^{\text {th }}, \ldots, 32^{\text {nd }}$ quarter of the job spell.

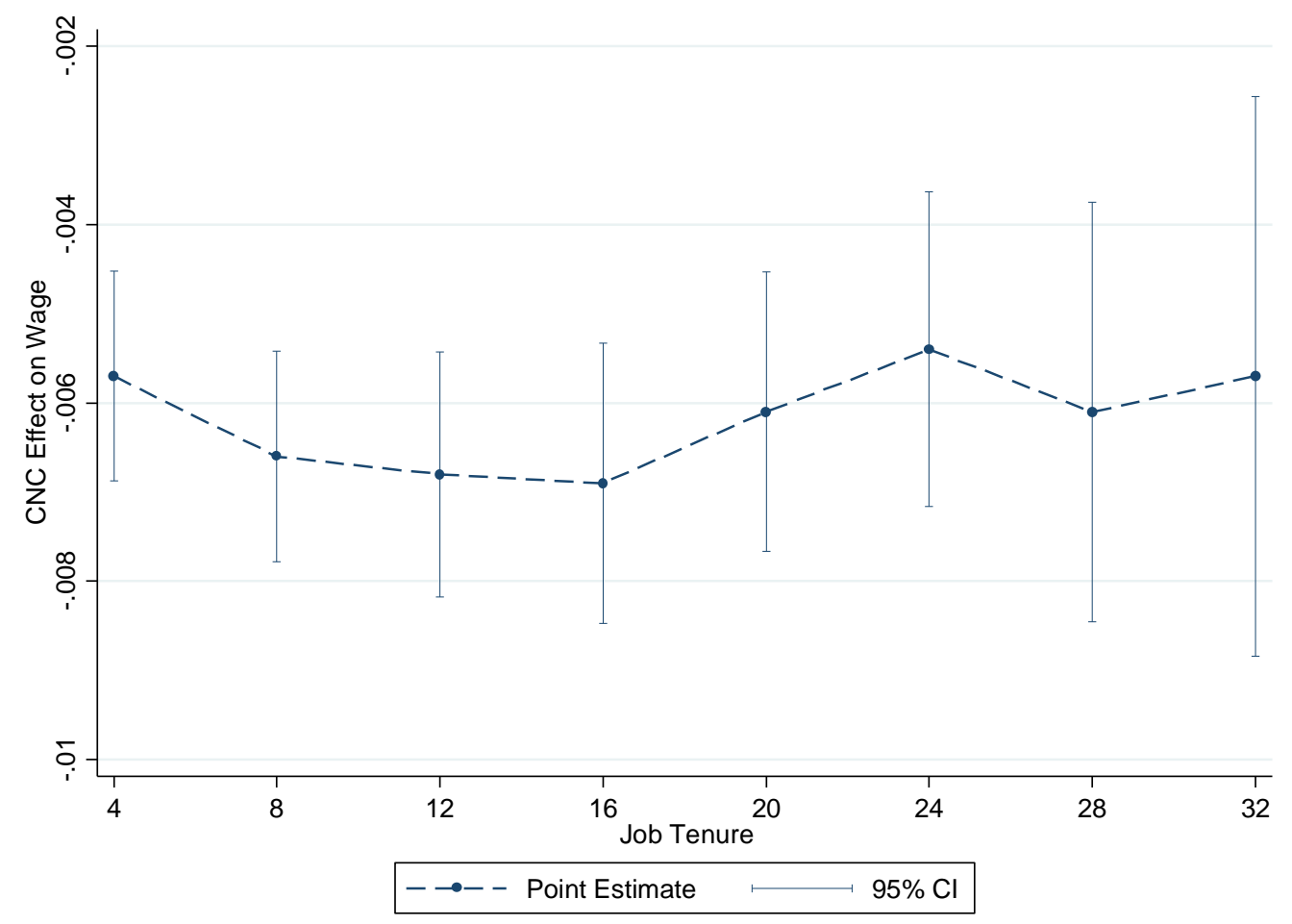




\section{Figure A4. Effect of CNC on Mobility of High-Tech Jobs: High-initial-wage Jobs vs Low-initial-wage Jobs}

This figure plots the coefficient estimates and the 95\% confidence intervals of the differential treatment effect of CNC enforceability on mobility, of high-initialwage jobs relative to low-initial-wage jobs within high-tech jobs. High-initial-wage jobs are defined as jobs with starting wage being above the $98^{\text {th }}$ percentile in the distribution of starting wages of jobs that have the same three-digit NAICS codes. Mobility is measured as the dummy variable for the spell surviving at $4^{\text {th }}$, $\ldots, 32^{\text {nd }}$ quarter of the job spell.

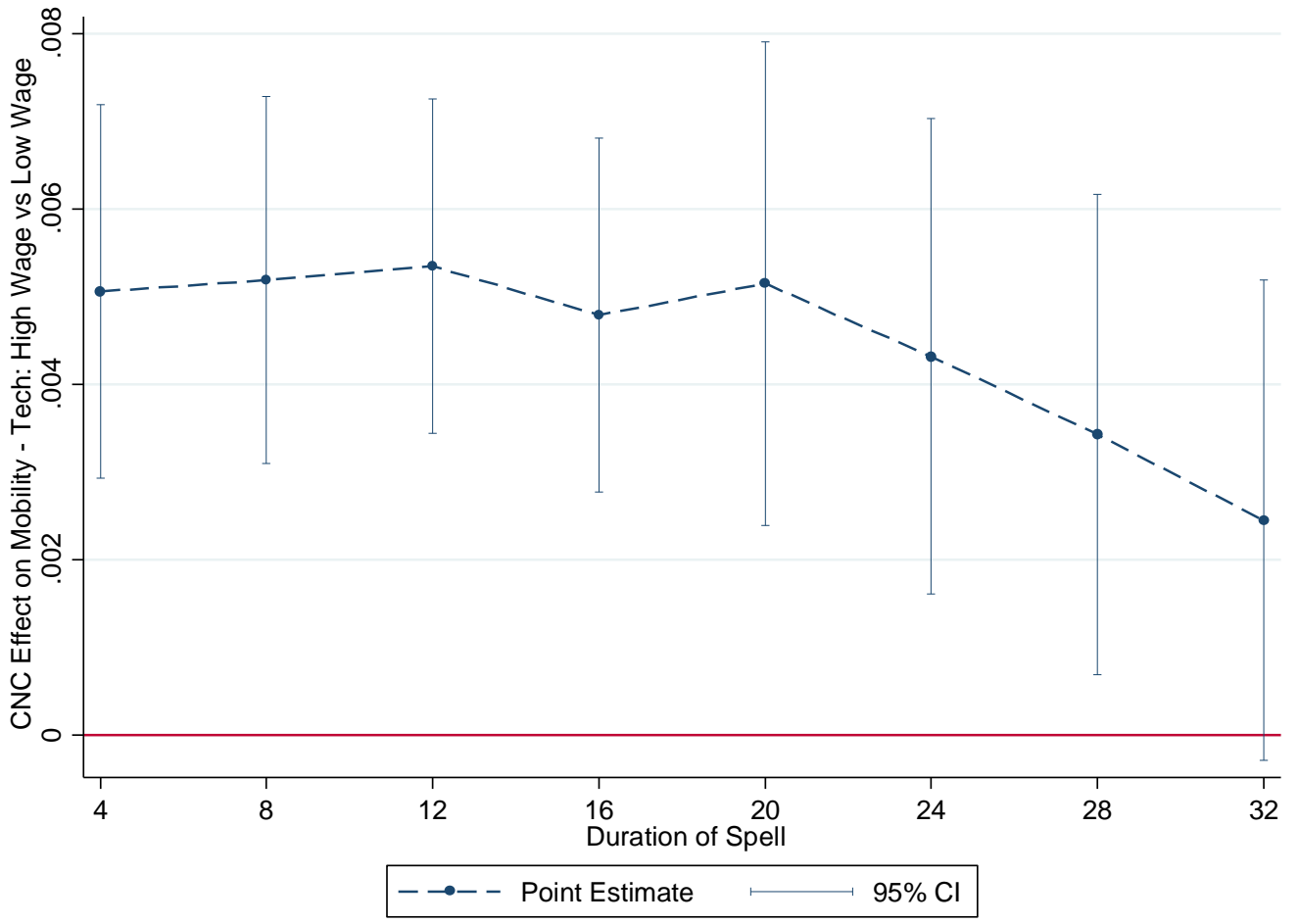




\section{Figure A5. Effect of CNC on Mobility of High-initial-wage Jobs: High-Tech Jobs vs Non-Tech Jobs}

This figure plots the coefficient estimates and the 95\% confidence intervals of the differential treatment effect of CNC enforceability on mobility, of high-tech jobs relative to non-tech jobs within high-initial-wage jobs. High-initial-wage jobs are defined as jobs with starting wage being above the $98^{\text {th }}$ percentile in the distribution of starting wages of jobs that have the same three-digit NAICS codes. Mobility is measured as the dummy variable for the spell surviving at $4^{\text {th }}, \ldots$, $32^{\text {nd }}$ quarter of the job spell.

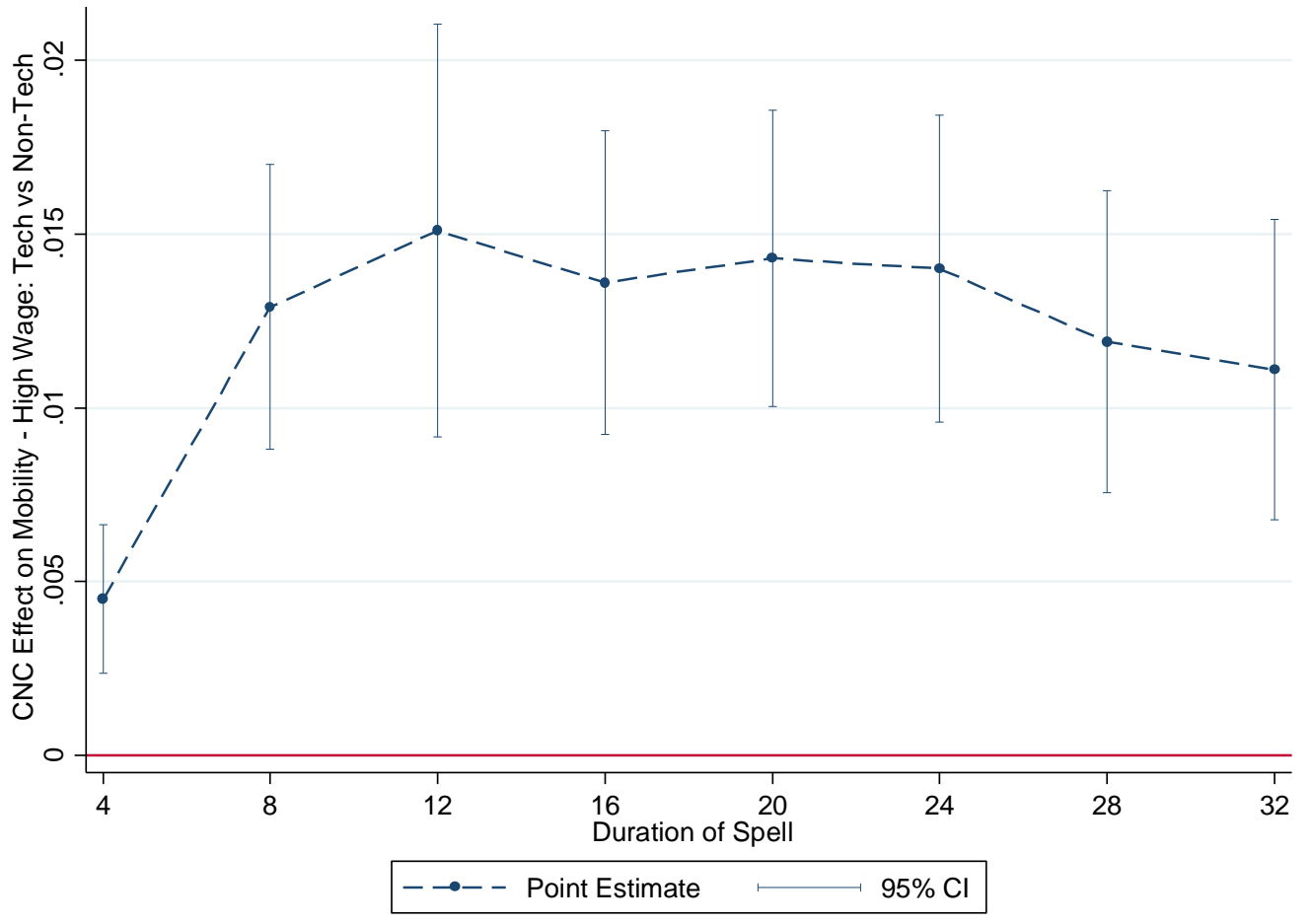




\section{Figure A6. Pseudo Difference-in-Difference-in-Differences: Effect of CNC on Mobility of High-Tech Jobs}

This figure plots the coefficient estimates and the 95\% confidence intervals of the pseudo difference-in-difference-in-differences treatment effect of CNC enforceability on mobility, of high-tech jobs relative to non-tech jobs, after differencing out the common unobservables across high-initial-wage jobs and lowinitial-wage jobs. High-initial-wage jobs are defined as jobs with starting wage being above the $98^{\text {th }}$ percentile in the distribution of starting wages of jobs that have the same three-digit NAICS codes. Mobility is measured as the dummy variable for the spell surviving at $4^{\text {th }}, \ldots, 32^{\text {nd }}$ quarter of the job spell.

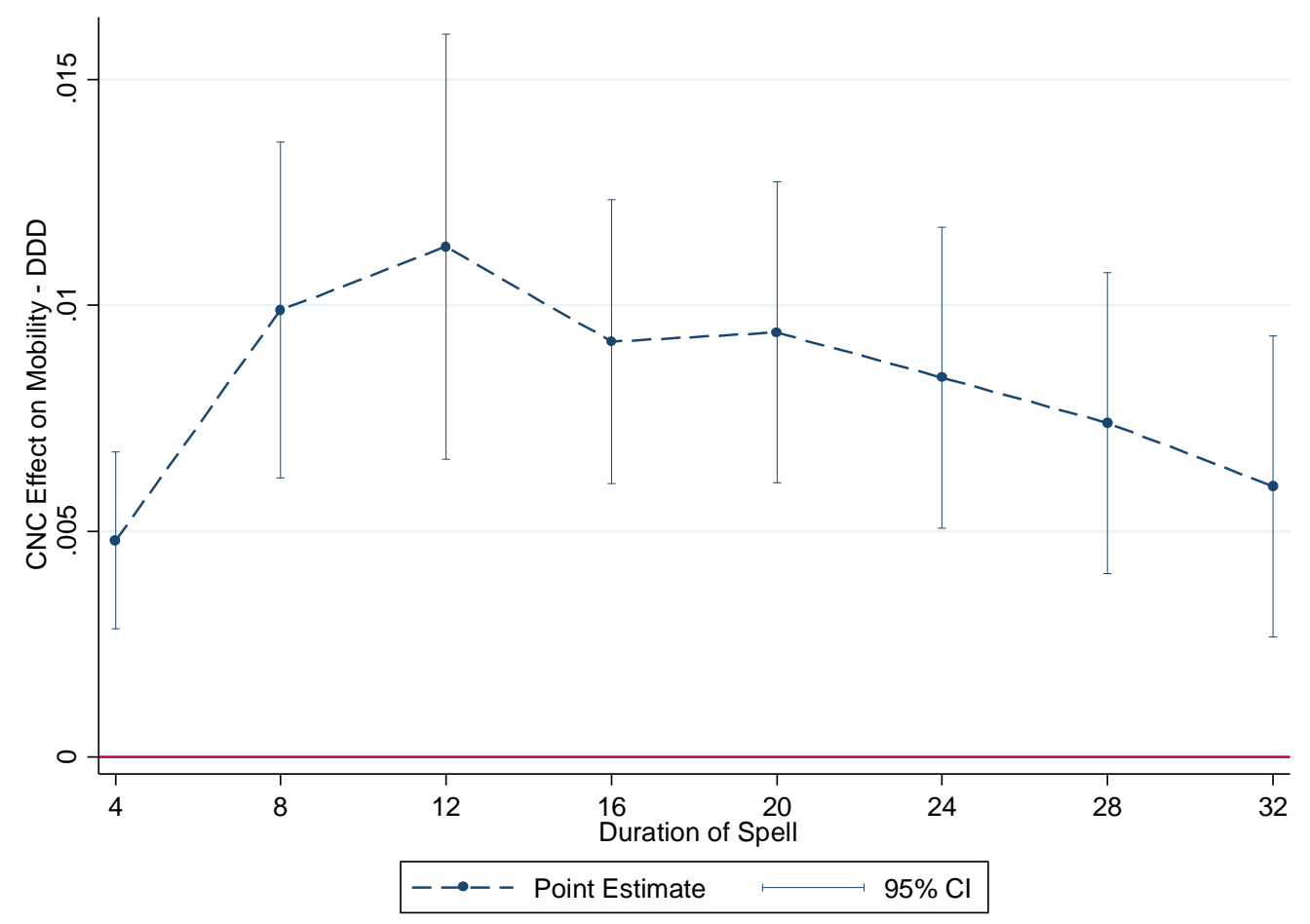




\section{Figure A7. Effect of CNC on Wage of High-Tech Jobs: High-initial-wage Jobs vs Low-initial-wage Jobs}

This figure plots the coefficient estimates and the 95\% confidence intervals of the differential treatment effect of CNC enforceability on wage, of high-initialwage jobs relative to low-initial-wage jobs within high-tech jobs. High-initial-wage jobs are defined as jobs with starting wage being above the $98^{\text {th }}$ percentile in the distribution of starting wages of jobs that have the same three-digit NAICS codes. Wage is the log of quarterly wage at $4^{\text {th }}, \ldots, 32^{\text {nd }}$ quarter of the job spell.

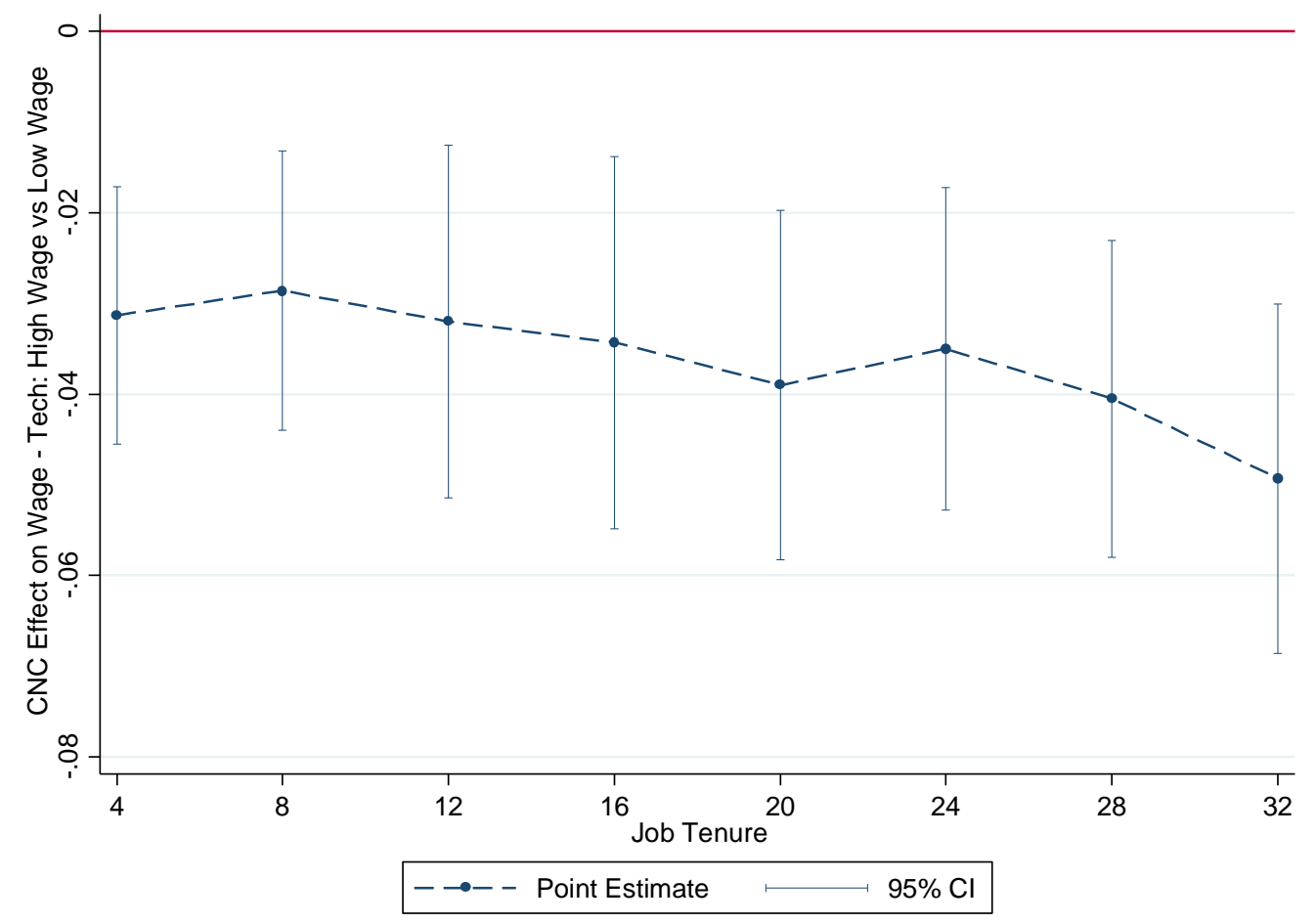




\section{Figure A8. Effect of CNC on Wage of High-initial-wage Jobs: High-Tech Jobs vs Non-Tech Jobs}

This figure plots the coefficient estimates and the 95\% confidence intervals of the differential treatment effect of CNC enforceability on wage, of high-tech jobs relative to non-tech jobs within high-initial-wage jobs. High-initial-wage jobs are defined as jobs with starting wage being above the $98^{\text {th }}$ percentile in the distribution of starting wages of jobs that have the same three-digit NAICS codes. Wage is the log of quarterly wage at $4^{\text {th }}, \ldots, 32^{\text {nd }}$ quarter of the job spell.

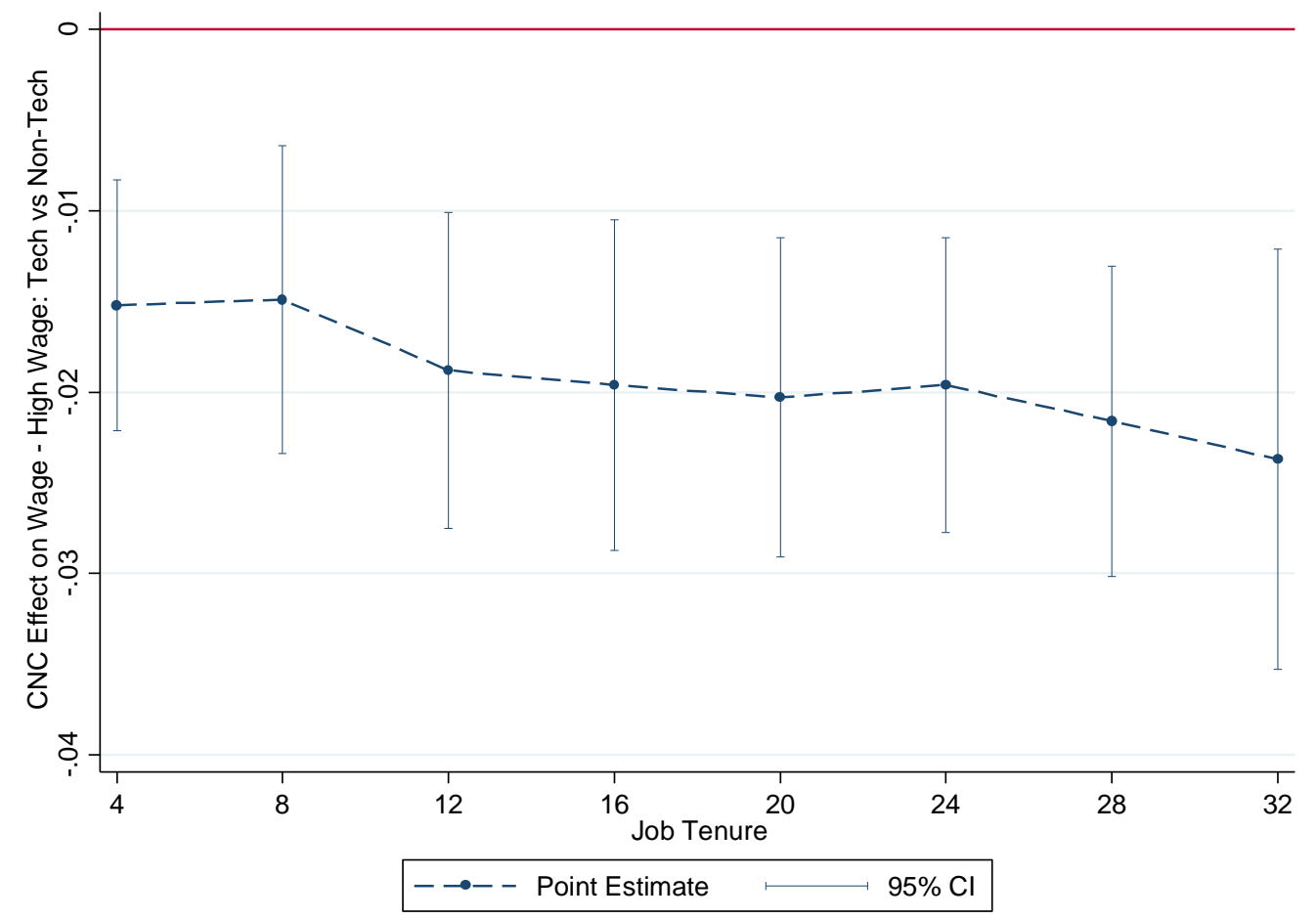




\section{Figure A9. Pseudo Difference-in-Difference-in-Differences: Effect of CNC on Wage of High-Tech Jobs}

This figure plots the coefficient estimates and the 95\% confidence intervals of the pseudo difference-in-difference-in-differences treatment effect of CNC enforceability on wage, of high-tech jobs relative to non-tech jobs, after differencing out the common unobservables across high-initial-wage jobs and lowinitial-wage jobs. High-initial-wage jobs are defined as jobs with starting wage being above the $98^{\text {th }}$ percentile in the distribution of starting wages of jobs that have the same three-digit NAICS codes. Wage is the $\log$ of quarterly wage at $4^{\text {th }}, \ldots, 32^{\text {nd }}$ quarter of the job spell.

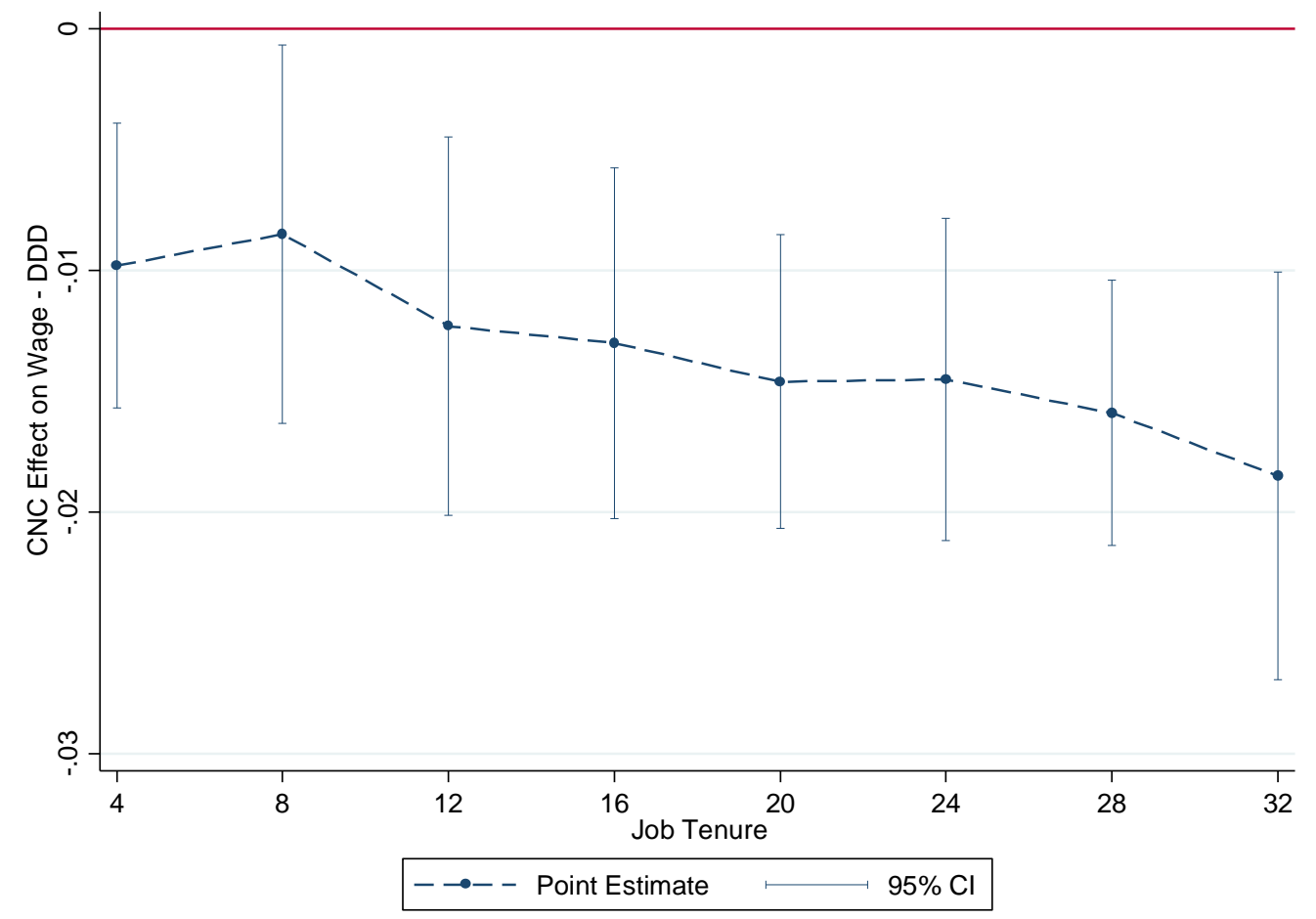




\section{Table A1. Summary Statistics of the Dependent Variables}

This table presents the summary statistics of the dependent variables reported. I $\{4\}-I\{32\}$ denote indicator variables for the job spell surviving in the $4^{\text {th }}-32^{\text {nd }}$ quarter since the job spell started. Log(job-spell) denotes the number of quarters the job lasted in logs. Log(wage4)-Log(wage32) denote quarterly wages at the $4^{\text {th }}-32^{\text {nd }}$ quarter since the job spell started. Log(cwage4)-Log(cwage32) denote cumulative wage at the $4^{\text {th }}-32^{\text {nd }}$ quarter since the job spell started, in logs. dLog(wage4)-dLog(wage32) denote the logged differences in quarterly wage at the $4^{\text {th }}-32^{\text {nd }}$ quarter since the job spell started and the initial wage of the job. $\log \left(\right.$ cjobs4)- $\log \left(\right.$ cjob32) denote cumulative number of jobs taken (in logs) in the $4^{\text {th }}-32^{\text {nd }}$ quarter of the worker's employment history. Log(cwageE4)Log(cwageE32) denote the worker's cumulative earnings (in logs) in the $4^{\text {th }}-32^{\text {nd }}$ quarter of the worker's employment history. Log(State4)-Log(State32) denote the cumulative number of switches in states, $\log (\mathrm{Ind} 4)-\log (\mathrm{Ind} 32)$ denote the cumulative number of switches in industries, and Log(StNoInd4)-Log(StNoInd32) denote the cumulative number of switches in states but not in industries, in the $4^{\text {th }}-32^{\text {nd }}$ quarter of the worker's employment history.

\begin{tabular}{|c|c|c|c|c|c|c|c|c|}
\hline Variable & Mean & St.Dev & Variable & Mean & St.Dev & Variable & Mean & St.Dev \\
\hline $\mathrm{I}\{4\}$ & 0.845 & 0.362 & dLog(wage4) & 0.049 & 0.465 & Log(State8) & 0.027 & 0.136 \\
\hline $\mathrm{I}\{8\}$ & 0.583 & 0.493 & dLog(wage8) & 0.076 & 0.520 & Log(State12) & 0.033 & 0.154 \\
\hline $\mathrm{I}\{12\}$ & 0.434 & 0.496 & dLog(wage12) & 0.101 & 0.546 & Log(State16) & 0.040 & 0.171 \\
\hline $\mathrm{I}\{16\}$ & 0.331 & 0.471 & dLog(wage16) & 0.128 & 0.566 & Log(State20) & 0.048 & 0.187 \\
\hline $\mathrm{I}\{20\}$ & 0.261 & 0.439 & dLog(wage20) & 0.151 & 0.582 & Log(State24) & 0.055 & 0.202 \\
\hline $\mathrm{I}\{24\}$ & 0.208 & 0.406 & dLog(wage24) & 0.169 & 0.595 & Log(State28) & 0.062 & 0.216 \\
\hline $\mathrm{I}\{28\}$ & 0.160 & 0.367 & dLog(wage28) & 0.191 & 0.614 & Log(State32) & 0.070 & 0.230 \\
\hline $\mathrm{I}\{32\}$ & 0.124 & 0.329 & dLog(wage32) & 0.211 & 0.632 & Log(Ind4) & 0.051 & 0.186 \\
\hline Log(job-spell) & 2.363 & 0.977 & Log(cjobs4) & 0.383 & 0.385 & Log(Ind8) & 0.106 & 0.270 \\
\hline Log(wage4) & 9.578 & 0.777 & Log(cjobs8) & 0.498 & 0.435 & Log(Ind12) & 0.152 & 0.327 \\
\hline Log(wage8) & 9.636 & 0.750 & Log(cjobs12) & 0.600 & 0.468 & Log(Ind16) & 0.195 & 0.371 \\
\hline Log(wage12) & 9.675 & 0.739 & Log(cjobs16) & 0.686 & 0.492 & Log(Ind20) & 0.234 & 0.408 \\
\hline Log(wage16) & 9.708 & 0.735 & Log(cjobs20) & 0.761 & 0.512 & Log(Ind24) & 0.270 & 0.438 \\
\hline Log(wage20) & 9.740 & 0.731 & Log(cjobs24) & 0.825 & 0.528 & Log(Ind28) & 0.304 & 0.464 \\
\hline Log(wage24) & 9.763 & 0.727 & Log(cjobs28) & 0.886 & 0.543 & Log(Ind32) & 0.340 & 0.489 \\
\hline Log(wage28) & 9.785 & 0.731 & Log(cjobs32) & 0.939 & 0.557 & Log(StNoInd4) & 0.002 & 0.034 \\
\hline Log(wage32) & 9.804 & 0.733 & Log(cwageE4) & 10.887 & 0.682 & Log(StNoInd8) & 0.005 & 0.058 \\
\hline Log(cwage4) & 11.003 & 0.885 & Log(cwageE8) & 11.631 & 0.654 & Log(StNoInd12) & 0.008 & 0.075 \\
\hline Log(cwage8) & 11.765 & 0.767 & Log(cwageE12) & 12.054 & 0.646 & Log(StNoInd16) & 0.011 & 0.089 \\
\hline Log(cwage12) & 12.204 & 0.714 & Log(cwageE16) & 12.353 & 0.642 & Log(StNoInd20) & 0.014 & 0.100 \\
\hline Log(cwage16) & 12.514 & 0.683 & Log(cwageE20) & 12.586 & 0.642 & Log(StNoInd24) & 0.016 & 0.110 \\
\hline Log(cwage20) & 12.762 & 0.663 & Log(cwageE24) & 12.778 & 0.643 & Log(StNoInd28) & 0.019 & 0.119 \\
\hline Log(cwage24) & 12.966 & 0.649 & Log(cwageE28) & 12.942 & 0.645 & Log(StNoInd32) & 0.021 & 0.127 \\
\hline Log(cwage28) & 13.137 & 0.641 & Log(cwageE32) & 13.083 & 0.646 & & & \\
\hline Log(cwage32) & 13.290 & 0.630 & Log(State4) & 0.017 & 0.108 & & & \\
\hline
\end{tabular}




\section{Table A2. Effect of CNC on High-Tech Workers' Mobility and Wage: Controlling for Local Labor Market Thickness}

This table reports the differential treatment effect of CNC enforceability on mobility and wage across job tenure, by industry (high-tech jobs vs. non-tech jobs), after controlling for total employment in state-three-digit NAICS code-year (in logs). In Panel A, the dependent variables are dummy variables for the job spell surviving at $4^{\text {th }}$, $\ldots, 32^{\text {nd }}$ quarter of the job spell for columns (1)-(8), and the log of length of job spells in number of quarters for column (9). In Panel B, the dependent variables are the $\log$ of quarterly wages at $4^{\text {th }}, \ldots, 32^{\text {nd }}$ quarter of the job spell. CNC Score is measured as the 2009 CNC enforcement index scores. Estimation samples are all jobs that are not right censored by the quarter for columns (1)-(8) of Panel A, and all jobs that started its spell in year 2000 or earlier for column (9) of Panel A, and all continuing jobs in the quarter for Panel B. All standard errors are clustered by state. ***, **, and * denote significance levels of $1 \%$, $5 \%$, and $10 \%$, respectively.

\section{Panel A. Mobility}

\begin{tabular}{|c|c|c|c|c|c|c|c|c|c|}
\hline $\begin{array}{l}\text { Dependent Variable: } \\
\text { Job spell survival at }\end{array}$ & $\begin{array}{c}(1) \\
\text { 4th qr }\end{array}$ & $\begin{array}{c}(2) \\
\text { 8th qr }\end{array}$ & $\begin{array}{c}(3) \\
\text { 12th qr }\end{array}$ & $\begin{array}{c}(4) \\
16 \text { th qr }\end{array}$ & $\begin{array}{c}5) \\
\text { 20th qr }\end{array}$ & $\begin{array}{c}(6) \\
\text { 24th qr }\end{array}$ & $\begin{array}{c}(7) \\
\text { 28th qr }\end{array}$ & $\begin{array}{c}(8) \\
\text { 32th qr }\end{array}$ & $\begin{array}{c}\text { (9) } \\
\text { Ln(job-spell) } \\
\end{array}$ \\
\hline Tech X CNC Score & $\begin{array}{r}-0.0005 \\
(0.0008)\end{array}$ & $\begin{array}{r}0.0029 * * \\
(0.0011)\end{array}$ & $\begin{array}{r}0.0037 * * * \\
(0.0009)\end{array}$ & $\begin{array}{r}0.0044 * * * \\
(0.0012)\end{array}$ & $\begin{array}{r}0.0049 * * * \\
(0.0010)\end{array}$ & $\begin{array}{r}0.0056^{* * *} \\
(0.0009)\end{array}$ & $\begin{array}{r}0.0045^{* * *} \\
(0.0008)\end{array}$ & $\begin{array}{r}0.0051^{* * *} \\
(0.0007)\end{array}$ & $\begin{array}{r}0.0146^{* * *} \\
(0.0028)\end{array}$ \\
\hline Observations & 12984300 & 12425700 & 11971100 & 11602500 & 11334900 & 11127400 & 10861700 & 10661700 & 6492100 \\
\hline R-squared & 0.2108 & 0.1742 & 0.1732 & 0.1768 & 0.1817 & 0.1836 & 0.1831 & 0.1885 & 0.2113 \\
\hline Fixed Effects & \multicolumn{9}{|c|}{ State + [Industry - Starting Year - Firm Size - Starting Wage - Starting Age - Sex] } \\
\hline Sample & \multicolumn{8}{|c|}{ All jobs that are not right censored by the quarter } & $\begin{array}{l}\text { Spell started } \\
2000 \text { or earlier }\end{array}$ \\
\hline
\end{tabular}

Panel B. Wage

\begin{tabular}{|c|c|c|c|c|c|c|c|c|}
\hline $\begin{array}{l}\text { Dependent Variable: } \\
\text { Log of wage at xth quarter }\end{array}$ & $\begin{array}{c}\text { (1) } \\
\text { 4th qr }\end{array}$ & $\begin{array}{c}(2) \\
\text { 8th qr }\end{array}$ & $\begin{array}{c}\text { (3) } \\
12 \text { th qr }\end{array}$ & $\begin{array}{c}(4) \\
16 \text { th qr }\end{array}$ & $\begin{array}{c}(5) \\
\text { 20th qr }\end{array}$ & $\begin{array}{c}\text { (6) } \\
\text { 24th qr }\end{array}$ & $\begin{array}{c}(7) \\
\text { 28th qr }\end{array}$ & $\begin{array}{c}\text { (8) } \\
\text { 32th qr }\end{array}$ \\
\hline Tech X CNC Score & $\begin{array}{r}-0.0057 * * * \\
(0.0006)\end{array}$ & $\begin{array}{r}-0.0065 * * * \\
(0.0006)\end{array}$ & $\begin{array}{r}-0.0067 * * * \\
(0.0007)\end{array}$ & $\begin{array}{r}-0.0068 * * * \\
(0.0008)\end{array}$ & $\begin{array}{r}-0.0059 * * * \\
(0.0009)\end{array}$ & $\begin{array}{r}-0.0052 * * * \\
(0.0010)\end{array}$ & $\begin{array}{r}-0.0058 * * * \\
(0.0013)\end{array}$ & $\begin{array}{r}-0.0056 * * * \\
(0.0017)\end{array}$ \\
\hline Observations & 10904200 & 7397200 & 5399500 & 4048400 & 3145300 & 2478900 & 1858400 & 1412600 \\
\hline R-squared & 0.6726 & 0.6090 & 0.5764 & 0.5570 & 0.5429 & 0.5323 & 0.5237 & 0.5114 \\
\hline Fixed Effects & \multicolumn{8}{|c|}{ State + [Industry - Starting Year - Firm Size - Starting Wage - Starting Age - Sex] } \\
\hline Sample & \multicolumn{8}{|c|}{ All continuing jobs in the quarter } \\
\hline
\end{tabular}




\section{Table A3. Effect of CNC on Mobility: Sub-Samples by Industry and Initial Wage: State X Industry Fixed Effects}

This table reports the differential treatment effect of CNC enforceability on mobility across sub-samples by industry (high-tech jobs vs non-tech jobs) and initial wage (high-initial-wage jobs vs low-initial-wage jobs) (dummy variable for the starting wage of the job being above the $98^{\text {th }}$ percentile in the distribution of starting wages of jobs that have the same three-digit NAICS codes), with state-industry (2 digit NAICS code) fixed effects. The dependent variables are dummy variables for the job spell surviving at $4^{\text {th }}, \ldots, 32^{\text {nd }}$ quarter of the job spell for columns (1)-(8), and the log of length of job spells in number of quarters for column (9). CNC Score is measured as the 2009 CNC enforcement index scores. Estimation samples are all jobs that are not right censored by the quarter for columns (1)-(8), and all jobs that started its spell in year 2000 or earlier for column (9). All standard errors are clustered by state. ***, **, and * denote significance levels of $1 \%, 5 \%$, and $10 \%$, respectively.

\begin{tabular}{|c|c|c|c|c|c|c|c|c|c|}
\hline $\begin{array}{l}\text { Dependent Variable } \\
\text { Job spell survival at: }\end{array}$ & $\begin{array}{c}(1) \\
\text { 4th qr }\end{array}$ & $\begin{array}{c}(2) \\
\text { 8th qr }\end{array}$ & $\begin{array}{c}\text { (3) } \\
\text { 12th qr }\end{array}$ & $\begin{array}{c}\text { (4) } \\
\text { 16th qr }\end{array}$ & $\begin{array}{c}\text { (5) } \\
\text { 20th qr }\end{array}$ & $\begin{array}{c}\text { (6) } \\
\text { 24th qr }\end{array}$ & $\begin{array}{c}\text { (7) } \\
\text { 28th qr }\end{array}$ & $\begin{array}{c}\text { (8) } \\
\text { 32th qr }\end{array}$ & $\begin{array}{c}(9) \\
\text { Ln(job-spell) }\end{array}$ \\
\hline $\begin{array}{l}\text { Tech X High-initial-wage } \\
\text { X CNC Score }\left(\beta_{1}\right)\end{array}$ & $\begin{array}{r}0.0050 * * * \\
(0.0010)\end{array}$ & $\begin{array}{r}0.0085^{* * *} \\
(0.0013)\end{array}$ & $\begin{array}{r}0.0096 * * * \\
(0.0015)\end{array}$ & $\begin{array}{r}0.0078 * * * \\
(0.0015)\end{array}$ & $\begin{array}{r}0.0081^{* * *} \\
(0.0017)\end{array}$ & $\begin{array}{r}0.0072 * * * \\
(0.0018)\end{array}$ & $\begin{array}{r}0.0064 * * * \\
(0.0018)\end{array}$ & $\begin{array}{r}0.0051 * * * \\
(0.0017)\end{array}$ & $\begin{array}{r}0.0185^{* * *} \\
(0.0037)\end{array}$ \\
\hline Tech X CNC Score $\left(\beta_{2}\right)$ & $\begin{array}{r}-0.0018 \\
(0.0013)\end{array}$ & $\begin{array}{r}-0.0009 \\
(0.0018)\end{array}$ & $\begin{array}{r}-0.0008 \\
(0.0016)\end{array}$ & $\begin{array}{r}0.0008 \\
(0.0017)\end{array}$ & $\begin{array}{r}0.0008 \\
(0.0013)\end{array}$ & $\begin{array}{r}0.0026 * * \\
(0.0012)\end{array}$ & $\begin{array}{r}0.0014 \\
(0.0013)\end{array}$ & $\begin{array}{r}0.0021^{* *} \\
(0.0009)\end{array}$ & $\begin{array}{r}0.0072 * * \\
(0.0032)\end{array}$ \\
\hline $\begin{array}{l}\text { High-initial-wage } X \\
\text { CNC Score }\left(\beta_{3}\right)\end{array}$ & $\begin{array}{r}-0.0001 \\
(0.0008)\end{array}$ & $\begin{array}{r}-0.0038^{* * *} \\
(0.0009)\end{array}$ & $\begin{array}{r}-0.0045^{* * *} \\
(0.0013)\end{array}$ & $\begin{array}{r}-0.0034^{* * *} \\
(0.0010)\end{array}$ & $\begin{array}{r}-0.0033^{* * * *} \\
(0.0010)\end{array}$ & $\begin{array}{r}-0.0032^{* * *} \\
(0.0009)\end{array}$ & $\begin{array}{r}-0.0033^{* * *} \\
(0.0007)\end{array}$ & $\begin{array}{r}-0.0028 * * * \\
(0.0007)\end{array}$ & $\begin{array}{l}-0.0055^{*} \\
(0.0030)\end{array}$ \\
\hline $\begin{array}{l}\text { \# of observations } \\
\text { R-squared }\end{array}$ & $\begin{array}{r}12984300 \\
0.2124 \\
\end{array}$ & $\begin{array}{r}12425700 \\
0.1772 \\
\end{array}$ & $\begin{array}{r}11971100 \\
0.1769 \\
\end{array}$ & $\begin{array}{r}11602500 \\
0.1802 \\
\end{array}$ & $\begin{array}{r}11334900 \\
0.1851 \\
\end{array}$ & $\begin{array}{r}11127400 \\
0.1867 \\
\end{array}$ & $\begin{array}{r}10861700 \\
0.1865 \\
\end{array}$ & $\begin{array}{r}10661700 \\
0.1916 \\
\end{array}$ & $\begin{array}{r}6492100 \\
0.2162 \\
\end{array}$ \\
\hline $\begin{array}{l}\text { High vs Low Wage in } \\
\text { Tech industry }(\beta 1+\beta 3) \\
\text { p value }\end{array}$ & $\begin{array}{r}0.00488 * * * \\
6.77 \mathrm{e}-06\end{array}$ & $\begin{array}{r}0.00464 * * * \\
1.93 \mathrm{e}-06\end{array}$ & $\begin{array}{r}0.00513^{* * * *} \\
4.94 \mathrm{e}-08\end{array}$ & $\begin{array}{r}0.00440 * * * \\
8.67 \mathrm{e}-06\end{array}$ & $\begin{array}{r}0.00481^{* * *} \\
0.000411\end{array}$ & $\begin{array}{r}0.00404 * * * \\
0.00368\end{array}$ & $\begin{array}{r}0.00312 * * \\
0.0261\end{array}$ & $\begin{array}{r}0.00233 \\
0.101\end{array}$ & $\begin{array}{r}0.0130 * * * \\
5.34 \mathrm{e}-06\end{array}$ \\
\hline $\begin{array}{l}\text { Tech vs Non-Tech in } \\
\text { High-initial-wage jobs } \\
(\beta 1+\beta 2) \\
\text { p value }\end{array}$ & $\begin{array}{r}0.00315^{* *} \\
0.0242\end{array}$ & $\begin{array}{r}0.00757 * * * \\
1.27 \mathrm{e}-05\end{array}$ & $0.00884^{* * *}$ & $0.00859 * * *$ & $0.00893 * * *$ & $0.00986 * * *$ & $0.00785 * * *$ & $0.00717^{* * *}$ & $0.0257 * * *$ \\
\hline Fixed Effects & \multicolumn{9}{|c|}{ [State-Industry] + [Industry - Starting Year - Firm Size - Starting Wage - Starting Age - Sex] } \\
\hline Sample & \multicolumn{8}{|c|}{ All jobs that are not right censored by the quarter } & $\begin{array}{l}\text { Spell started } \\
2000 \text { or } \\
\text { earlier } \\
\end{array}$ \\
\hline
\end{tabular}


Table A4. Effect of CNC on Wage across Job Tenure: Sub-Samples by Industry and Initial Wage: State X Industry Fixed Effects

This table reports the differential treatment effect of CNC enforceability on wage throughout job tenure, across sub-samples by industry (high-tech jobs vs nontech jobs) and initial wage (high-initial-wage jobs vs low-initial-wage jobs) (dummy variable for the starting wage of the job being above the $98^{\text {th }}$ percentile in the distribution of starting wages of jobs that have the same three-digit NAICS codes), with state-industry (2 digit NAICS code) fixed effects. The dependent variables are the log of quarterly wages at $4^{\text {th }}, \ldots, 32^{\text {nd }}$ quarter of the job spell. CNC Score is measured as the 2009 CNC enforcement index scores. All standard errors are clustered by state. $* * *, * *$, and * denote significance levels of $1 \%, 5 \%$, and $10 \%$, respectively.

\begin{tabular}{|c|c|c|c|c|c|c|c|c|}
\hline $\begin{array}{l}\text { Dependent Variable } \\
\text { Log wage at xth quarter }\end{array}$ & $\begin{array}{c}\text { (1) } \\
\text { 4th qr }\end{array}$ & $\begin{array}{c}(2) \\
\text { 8th qr }\end{array}$ & $\begin{array}{c}\text { (3) } \\
12 \text { th qr }\end{array}$ & $\begin{array}{c}\text { (4) } \\
16 \text { th qr }\end{array}$ & $\begin{array}{c}(5) \\
\text { 20th qr }\end{array}$ & $\begin{array}{c}\text { (6) } \\
\text { 24th qr }\end{array}$ & $\begin{array}{c}\text { (7) } \\
\text { 28th qr }\end{array}$ & $\begin{array}{c}\text { (8) } \\
\text { 32th qr }\end{array}$ \\
\hline $\begin{array}{l}\text { Tech X High-initial-wage } \\
\text { X CNC Score }\left(\beta_{1}\right)\end{array}$ & $\begin{array}{r}-0.0089 * * * \\
(0.0030)\end{array}$ & $\begin{array}{r}-0.0077 * \\
(0.0040)\end{array}$ & $\begin{array}{r}-0.0121^{* * *} \\
(0.0040)\end{array}$ & $\begin{array}{r}-0.0124^{* * *} \\
(0.0036)\end{array}$ & $\begin{array}{r}-0.0140 * * * \\
(0.0031)\end{array}$ & $\begin{array}{r}-0.0138 * * * \\
(0.0036)\end{array}$ & $\begin{array}{r}-0.0151^{* * *} \\
(0.0029)\end{array}$ & $\begin{array}{r}-0.0185^{* * *} \\
(0.0044)\end{array}$ \\
\hline Tech X CNC Score $\left(\beta_{2}\right)$ & $\begin{array}{r}-0.0041^{* * *} \\
(0.0006)\end{array}$ & $\begin{array}{r}-0.0052^{* * *} \\
(0.0006)\end{array}$ & $\begin{array}{r}-0.0044^{* * *} \\
(0.0008)\end{array}$ & $\begin{array}{r}-0.0047 * * * \\
(0.0007)\end{array}$ & $\begin{array}{r}-0.0034^{* * *} \\
(0.0005)\end{array}$ & $\begin{array}{r}-0.0038^{* * *} \\
(0.0006)\end{array}$ & $\begin{array}{r}-0.0044^{* * *} \\
(0.0007)\end{array}$ & $\begin{array}{r}-0.0079 * * * \\
(0.0012)\end{array}$ \\
\hline $\begin{array}{l}\text { High-initial-wage X CNC } \\
\text { Score }\left(\beta_{3}\right)\end{array}$ & $\begin{array}{r}-0.0225^{* * *} \\
(0.0038)\end{array}$ & $\begin{array}{r}-0.0209 * * * \\
(0.0038)\end{array}$ & $\begin{array}{r}-0.0202 * * * \\
(0.0061)\end{array}$ & $\begin{array}{r}-0.0224 * * * \\
(0.0068)\end{array}$ & $\begin{array}{r}-0.0255^{* * *} \\
(0.0085)\end{array}$ & $\begin{array}{r}-0.0215^{* * *} \\
(0.0078)\end{array}$ & $\begin{array}{r}-0.0259 * * * \\
(0.0085)\end{array}$ & $\begin{array}{r}-0.0314^{* * *} \\
(0.0100)\end{array}$ \\
\hline $\begin{array}{l}\text { \# of observations } \\
\text { R-squared }\end{array}$ & $\begin{array}{r}10904200 \\
0.6731 \\
\end{array}$ & $\begin{array}{r}7397200 \\
0.6096 \\
\end{array}$ & $\begin{array}{r}5399500 \\
0.5772 \\
\end{array}$ & $\begin{array}{r}4048400 \\
0.5580 \\
\end{array}$ & $\begin{array}{r}3145300 \\
0.5442 \\
\end{array}$ & $\begin{array}{r}2478900 \\
0.5339 \\
\end{array}$ & $\begin{array}{r}1858400 \\
0.5256 \\
\end{array}$ & $\begin{array}{r}1412600 \\
0.5135 \\
\end{array}$ \\
\hline $\begin{array}{l}\text { High vs Low Wage in } \\
\text { Tech industry }\left(\beta_{1}+\beta_{3}\right) \\
\text { p value }\end{array}$ & $\begin{array}{r}-0.0315 * * * \\
1.42 \mathrm{e}-05\end{array}$ & $\begin{array}{r}-0.0287^{* * * *} \\
0.000255\end{array}$ & $\begin{array}{r}-0.0323 * * * \\
0.00109\end{array}$ & $\begin{array}{r}-0.0348 * * * \\
0.000833\end{array}$ & $\begin{array}{r}-0.0395 * * * \\
6.23 \mathrm{e}-05\end{array}$ & $\begin{array}{r}-0.0353^{* * *} \\
0.000107\end{array}$ & $\begin{array}{r}-0.0410 * * * \\
4.41 \mathrm{e}-06\end{array}$ & $\begin{array}{r}-0.0499 * * * \\
4.90 \mathrm{e}-07\end{array}$ \\
\hline $\begin{array}{l}\text { Tech vs Non-Tech in } \\
\text { High-initial-wage jobs } \\
\left(\beta_{1}+\beta_{2}\right) \\
\text { p value }\end{array}$ & $\begin{array}{r}-0.0130 * * * \\
4.76 \mathrm{e}-05 \\
\end{array}$ & $\begin{array}{r}-0.0130 * * * \\
0.00193 \\
\end{array}$ & $\begin{array}{r}-0.0165 * * * \\
0.000137\end{array}$ & $\begin{array}{r}-0.0171^{* * *} \\
6.84 \mathrm{e}-05 \\
\end{array}$ & $\begin{array}{r}-0.0174 * * * \\
5.05 \mathrm{e}-06\end{array}$ & $-0.0176 * * *$ & $\begin{array}{r}-0.0194 * * * \\
1.02 \mathrm{e}-06\end{array}$ & $-0.0264 * * *$ \\
\hline Fixed Effects & \multicolumn{8}{|c|}{ [State-Industry] + [Industry - Starting Year - Firm Size - Starting Wage - Starting Age - Sex] } \\
\hline Sample & \multicolumn{8}{|c|}{ All continuing jobs in the quarter } \\
\hline
\end{tabular}




\section{Table A5. Effect of CNC on the Probability of High-Tech Workers' Switching States or Industries at Job Transition}

This table reports the differential treatment effect of CNC enforceability on the probability of state switches, industry switches, state switches but not industry switches, and industry switches but not state switches at job transition by industry (high-tech jobs vs. non-tech jobs). The dependent variables are dummy variables for switching states at job transitions in Panel A, dummy variables for three-digit NAICS code switches at job transitions in Panel B, dummy variables for changes in states, but no changes in three-digit NAICS codes at job transitions in Panel C, and dummy variables for changes in three-digit NAICS codes but no changes in states in Panel D, for job transitions occurring at any point in time in job tenure for column (1), and for job transitions occurring at $4^{\text {th }}, \ldots, 32^{\text {nd }}$ quarter of job tenure in columns (2) $\sim(9)$. The high-tech job dummy is that of the pre-transition job. CNC Score is measured as the 2009 CNC enforcement index scores of the state in which the pre-transition job is geographically located in. The job-level fixed effects controls for the job characteristics of the pre-transition job. All standard errors are clustered by state. ***, **, and * denote significance levels of $1 \%, 5 \%$, and $10 \%$, respectively.

\begin{tabular}{|c|c|c|c|c|c|c|c|c|c|}
\hline Panel A. Switch States & (1) & $(2)$ & (3) & (4) & (5) & (6) & (7) & (8) & (9) \\
\hline $\begin{array}{l}\text { Dependent Variable: Dummy } \\
\text { for switching state at }\end{array}$ & $\begin{array}{l}\text { During job } \\
\text { tenure }\end{array}$ & 4th qr & 8th qr & 12th qr & 16th qr & 20th qr & 24th qr & 28th qr & 32th qr \\
\hline Tech X CNC Score & $\begin{array}{c}0.0106 * \\
(0.0062)\end{array}$ & $\begin{array}{r}0.0087 \\
(0.0076)\end{array}$ & $\begin{array}{l}0.0103 * \\
(0.0059)\end{array}$ & $\begin{array}{r}0.0126 * * \\
(0.0059)\end{array}$ & $\begin{array}{r}0.0088 \\
(0.0067)\end{array}$ & $\begin{array}{r}0.012 \\
(0.0072)\end{array}$ & $\begin{array}{r}0.0122 \\
(0.0072)\end{array}$ & $\begin{array}{l}0.0139 * \\
(0.0069)\end{array}$ & $\begin{array}{r}0.005 \\
(0.0099)\end{array}$ \\
\hline R-squared & 0.1194 & 0.1801 & 0.2047 & 0.2615 & 0.3083 & 0.3605 & 0.4086 & 0.4609 & 0.5054 \\
\hline Panel B. Switch Industry & $(1)$ & (2) & (3) & (4) & (5) & (6) & (7) & (8) & (9) \\
\hline $\begin{array}{l}\text { Dependent Variable: Dummy } \\
\text { for switching industry at }\end{array}$ & $\begin{array}{l}\text { During job } \\
\text { tenure }\end{array}$ & 4th qr & 8th qr & 12th qr & 16th qr & 20th qr & 24th qr & 28th qr & 32th qr \\
\hline Tech X CNC Score & $\begin{array}{r}0.0027 \\
(0.0029)\end{array}$ & $\begin{array}{r}0.0018 \\
(0.0028)\end{array}$ & $\begin{array}{r}0.0006 \\
(0.0028)\end{array}$ & $\begin{array}{r}0.0046 \\
(0.0028)\end{array}$ & $\begin{array}{r}0.0006 \\
(0.0037)\end{array}$ & $\begin{array}{r}0.0062 \\
(0.0038)\end{array}$ & $\begin{array}{r}0.0036 \\
(0.0046)\end{array}$ & $\begin{array}{r}0.0089 * * \\
(0.0033)\end{array}$ & $\begin{array}{r}-0.0043 \\
(0.0061)\end{array}$ \\
\hline R-squared & 0.1126 & 0.203 & 0.1901 & 0.242 & 0.2808 & 0.3423 & 0.3833 & 0.4379 & 0.4729 \\
\hline \# of observations & 12320000 & 4349000 & 2983000 & 1686000 & 1029000 & 679000 & 491000 & 345000 & 238000 \\
\hline Fixed Effects & \multicolumn{9}{|c|}{ State + [Industry - Starting Year - Firm Size - Starting Wage - Starting Age - Sex] } \\
\hline Sample & $\begin{array}{c}\text { All jobs in } \\
\text { transition }\end{array}$ & \multicolumn{8}{|c|}{ All jobs in transitions in the quarter } \\
\hline
\end{tabular}




\begin{tabular}{|c|c|c|c|c|c|c|c|c|c|}
\hline $\begin{array}{l}\text { Panel C. Switch State but not } \\
\text { Industry } \\
\text { Dependent Variable: Dummy for } \\
\text { switching state but not industry at }\end{array}$ & $\begin{array}{l}\text { (1) } \\
\text { During job } \\
\text { tenure }\end{array}$ & (2) & 8th qr & 12th qr & 16th qr & 20th qr & $\begin{array}{l}\text { (7) } \\
\text { 24th qr }\end{array}$ & $\begin{array}{l}\text { (8) } \\
\text { 28th qr }\end{array}$ & $\begin{array}{l}\text { (9) } \\
\text { 32th qr }\end{array}$ \\
\hline Tech X CNC Score & $\begin{array}{r}0.0016^{* * *} \\
(0.0004)\end{array}$ & $\begin{array}{r}0.0014^{* *} \\
(0.0006)\end{array}$ & $\begin{array}{r}0.0021^{* * *} \\
(0.0005)\end{array}$ & $\begin{array}{r}0.0021 * * * \\
(0.0004)\end{array}$ & $\begin{array}{r}0.0014 * * * \\
(0.0003)\end{array}$ & $\begin{array}{r}0.0014 * * * \\
(0.0003)\end{array}$ & $\begin{array}{r}0.0013 * * * \\
(0.0003)\end{array}$ & $\begin{array}{r}0.0007 * * \\
(0.0003)\end{array}$ & $\begin{array}{r}0.0008 \\
(0.0005)\end{array}$ \\
\hline R-squared & 0.0486 & 0.096 & 0.1174 & 0.1603 & 0.2022 & 0.2524 & 0.2872 & 0.3324 & 0.3769 \\
\hline $\begin{array}{l}\text { Panel D. Switch Industry but } \\
\text { not State }\end{array}$ & (1) & (2) & (3) & (4) & (5) & (6) & (7) & (8) & (9) \\
\hline $\begin{array}{l}\text { Dependent Variable: Dummy for } \\
\text { switching industry but not state at }\end{array}$ & $\begin{array}{l}\text { During job } \\
\text { tenure }\end{array}$ & 4th qr & 8th qr & 12th qr & 16th qr & 20th qr & 24th qr & 28th qr & 32th qr \\
\hline Tech X CNC Score & $\begin{array}{l}-0.0063^{*} \\
(0.0034)\end{array}$ & $\begin{array}{l}-0.0055 \\
(0.0045)\end{array}$ & $\begin{array}{r}-0.0076^{* *} \\
(0.0031)\end{array}$ & $\begin{array}{l}-0.0059 \\
(0.0035)\end{array}$ & $\begin{array}{l}-0.0068 * \\
(0.0034)\end{array}$ & $\begin{array}{r}-0.0044 \\
(0.0039)\end{array}$ & $\begin{array}{r}-0.0073 * * \\
(0.0035)\end{array}$ & $\begin{array}{r}-0.0043 \\
(0.0047)\end{array}$ & $\begin{array}{r}-0.0085^{* *} \\
(0.0040)\end{array}$ \\
\hline R-squared & 0.0992 & 0.1692 & 0.1745 & 0.2235 & 0.2732 & 0.3328 & 0.3713 & 0.4223 & 0.4590 \\
\hline \# of observations & 12320000 & 4349000 & 2983000 & 1686000 & 1029000 & 679000 & 491000 & 345000 & 238000 \\
\hline Fixed Effects & \multicolumn{9}{|c|}{ State + [Industry - Starting Year - Firm Size - Starting Wage - Starting Age - Sex] } \\
\hline Sample & $\begin{array}{l}\text { All jobs in } \\
\text { transition }\end{array}$ & \multicolumn{8}{|c|}{ All jobs in transitions in the quarter } \\
\hline
\end{tabular}




\section{Table A6. Effect of CNC on High-Tech Workers' Unemployment Spell}

This table reports the differential treatment effect of CNC enforceability on the length of unemployment spell by industry (high-tech jobs vs. non-tech jobs). Unemployment is defined by the missing spell between two non-continuous job spells. The dependent variable is the log of length of unemployment spells in number of quarters. The high-tech job dummy is that of the pre-unemployment job. CNC Score is measured as the 2009 CNC enforcement index scores of the pre-unemployment job. The job-level fixed effects controls for the job characteristics of the pre-unemployment job. Estimation sample consists of all spells between non-continuous job spells. All standard errors are clustered by state. ***, **, and * denote significance levels of $1 \%, 5 \%$, and $10 \%$, respectively.

Dependent Variable

Tech X CNC Score

\# of observations

R-squared

Fixed Effects

Sample
$-0.0051$

(0.0033)

4540000

0.1241
Ln(unemployment-spell)

Firm Size - St


Table A7. Effect of CNC (in Ranks) on High-Tech Workers' Mobility and Wage across Job Tenure

This table reports the differential treatment effect of CNC enforceability on mobility by industry (high-tech jobs vs. non-tech jobs) in Panel A, and on wage across job tenure by industry in Panel B. The dependent variables are dummy variables for the job spell surviving at $4^{\text {th }}, 8^{\text {th }}, \ldots, 32^{\text {nd }}$ quarter of the job spell for column $(1) \sim(8)$ of Panel A, and the log of length of job spells in number of quarters for column (9) of Panel A, the log of quarterly wages at $4^{\text {th }}, 8^{\text {th }}, \ldots ., 32^{\text {nd }}$ quarter of the job spell for Panel B. CNC Rank is measured as the ranks of the 2009 CNC enforcement index scores. Estimation samples are all jobs that are not right censored by the quarter for columns (1) (8) of Panel A, all jobs that started its spell in year 2000 or earlier for column (9) of Panel A, and all continuing jobs in the quarter for Panel B. All standard errors are clustered by state. ${ }^{* * *}, * *$, and $*$ denote significance levels of $1 \%, 5 \%$, and $10 \%$, respectively.

\section{Panel A. Mobility}

\begin{tabular}{|c|c|c|c|c|c|c|c|c|c|}
\hline $\begin{array}{l}\text { Dependent Variable: } \\
\text { Job spell survival at }\end{array}$ & $\begin{array}{c}\text { (1) } \\
\text { 4th qr }\end{array}$ & $\begin{array}{c}(2) \\
\text { 8th qr }\end{array}$ & $\begin{array}{c}\text { (3) } \\
12 \text { th qr }\end{array}$ & $\begin{array}{c}\text { (4) } \\
\text { 16th qr }\end{array}$ & $\begin{array}{c}(5) \\
\text { 20th qr }\end{array}$ & $\begin{array}{c}\text { (6) } \\
\text { 24th qr }\end{array}$ & $\begin{array}{c}\text { (7) } \\
\text { 28th qr }\end{array}$ & $\begin{array}{c}\text { (8) } \\
\text { 32th qr }\end{array}$ & $\begin{array}{c}\text { (9) } \\
\text { Ln(job-spell) }\end{array}$ \\
\hline Tech X CNC Rank & $\begin{array}{r}0.0004 \\
(0.0012)\end{array}$ & $\begin{array}{r}0.0052 * * \\
(0.0021)\end{array}$ & $\begin{array}{r}0.0065^{* * *} \\
(0.0021)\end{array}$ & $\begin{array}{r}0.0060 * * \\
(0.0028)\end{array}$ & $\begin{array}{r}0.0073 * * * \\
(0.0024)\end{array}$ & $\begin{array}{r}0.0085^{* * *} \\
(0.0021)\end{array}$ & $\begin{array}{r}0.0064 * * * \\
(0.0023)\end{array}$ & $\begin{array}{r}0.0072 * * * \\
(0.0021)\end{array}$ & $\begin{array}{r}0.0224^{* * *} \\
(0.0063)\end{array}$ \\
\hline \# of observations & 12984300 & 12425700 & 11971100 & 11602500 & 11334900 & 11127400 & 10861700 & 10661700 & 6492100 \\
\hline R-squared & 0.2108 & 0.1741 & 0.1731 & 0.1767 & 0.1817 & 0.1835 & 0.1831 & 0.1884 & 0.2112 \\
\hline Fixed Effects & \multicolumn{9}{|c|}{ State + [Industry - Starting Year - Firm Size - Starting Wage - Starting Age - Sex] } \\
\hline Sample & \multicolumn{8}{|c|}{ All jobs that are not right censored by the quarter } & $\begin{array}{l}\text { Spell started } \\
2000 \text { or earlier }\end{array}$ \\
\hline
\end{tabular}

\section{Panel B. Wage}

\begin{tabular}{|c|c|c|c|c|c|c|c|c|}
\hline $\begin{array}{l}\text { Dependent Variable } \\
\text { Log of wage at xth quarter }\end{array}$ & $\begin{array}{c}\text { (1) } \\
\text { 4th qr }\end{array}$ & $\begin{array}{c}(2) \\
\text { 8th qr }\end{array}$ & $\begin{array}{c}(3) \\
12 \text { th qr }\end{array}$ & $\begin{array}{c}(4) \\
16 \text { th qr }\end{array}$ & $\begin{array}{c}(5) \\
\text { 20th qr }\end{array}$ & $\begin{array}{c}\text { (6) } \\
\text { 24th qr }\end{array}$ & $\begin{array}{c}(7) \\
\text { 28th qr }\end{array}$ & $\begin{array}{c}\text { (8) } \\
\text { 32th qr }\end{array}$ \\
\hline Tech X CNC Rank & $\begin{array}{r}-0.0085 * * * \\
(0.0015)\end{array}$ & $\begin{array}{r}-0.0087 * * * \\
(0.0027)\end{array}$ & $\begin{array}{r}-0.0101 * * * \\
(0.0024)\end{array}$ & $\begin{array}{r}-0.0101^{* * *} \\
(0.0021)\end{array}$ & $\begin{array}{r}-0.0097 * * * \\
(0.0020)\end{array}$ & $\begin{array}{r}-0.0092 * * * \\
(0.0018)\end{array}$ & $\begin{array}{r}-0.0103^{* * *} \\
(0.0026)\end{array}$ & $\begin{array}{r}-0.0113^{* * *} \\
(0.0032)\end{array}$ \\
\hline \# of observations & 10904200 & 7397200 & 5399500 & 4048400 & 3145300 & 2478900 & 1858400 & 1412600 \\
\hline R-squared & 0.6726 & 0.6089 & 0.5764 & 0.5570 & 0.5429 & 0.5323 & 0.5237 & 0.5114 \\
\hline Fixed Effects & \multicolumn{8}{|c|}{ State + [Industry - Starting Year - Firm Size - Starting Wage - Starting Age - Sex] } \\
\hline Sample & \multicolumn{8}{|c|}{ All continuing jobs in the quarter } \\
\hline
\end{tabular}




\section{Table A8. Effect of CNC (in Ranks) on Mobility and Wage across Job Tenure: Sub-Samples by Industry and Initial Wage}

This table reports the differential treatment effect of CNC enforceability on mobility and wage throughout job tenure, across sub-samples by industry (high-tech jobs vs non-tech jobs) and initial wage (high-initial-wage jobs vs low-initial-wage jobs). High-initial-wage jobs are jobs whose starting wage is above the 98th percentile in the distribution of starting wages of jobs that have the same three-digit NAICS codes. The dependent variables are dummy variables for the job spell surviving at $4^{\text {th }}, 12^{\text {th }}, 20^{\text {th }}, 28^{\text {th }}$ quarter of the job spell for columns (1)-(4), and the log of length of job spells in number of quarters for column (5), the log of quarterly wages at $4^{\text {th }}, 12^{\text {th }}, 20^{\text {th }}, 28^{\text {th }}$ quarter of the job spell for columns (6) (9). CNC Rank is measured as the ranks of the 2009 CNC enforcement index scores. Estimation samples are all jobs that are not right censored by the quarter for columns (1) (4), all jobs that started its spell in year 2000 or earlier for column (5), and all continuing jobs in the quarter for columns (6) (9). All standard errors are clustered by state. ***, **, and * denote significance levels of $1 \%$, $5 \%$, and $10 \%$, respectively.

\begin{tabular}{|c|c|c|c|c|c|c|c|c|c|}
\hline \multirow[b]{2}{*}{ Dependent Variable } & \multicolumn{5}{|c|}{ Job spell survival at } & \multicolumn{4}{|c|}{ Log of wage at } \\
\hline & $\begin{array}{c}(1) \\
\text { 4th qr }\end{array}$ & $\begin{array}{c}\text { (2) } \\
\text { 12th qr }\end{array}$ & $\begin{array}{c}\text { (3) } \\
\text { 20th qr }\end{array}$ & $\begin{array}{c}\text { (4) } \\
\text { 28th qr }\end{array}$ & $\begin{array}{c}\text { (5) } \\
\text { Ln(job-spell) }\end{array}$ & $\begin{array}{c}\text { (6) } \\
\text { 4th qr }\end{array}$ & $\begin{array}{c}\text { (7) } \\
\text { 12th qr }\end{array}$ & $\begin{array}{c}\text { (8) } \\
\text { 20th qr }\end{array}$ & $\begin{array}{c}\text { (9) } \\
\text { 28th qr }\end{array}$ \\
\hline $\begin{array}{l}\text { Tech X High-initial-wage } \\
\text { X CNC Rank }\left(\beta_{1}\right)\end{array}$ & $\begin{array}{r}0.0087 * * * \\
(0.0014)\end{array}$ & $\begin{array}{r}0.0210 * * * \\
(0.0067)\end{array}$ & $\begin{array}{r}0.0183 * * * \\
(0.0043)\end{array}$ & $\begin{array}{r}0.0139 * * * \\
(0.0038)\end{array}$ & $\begin{array}{r}0.0425^{* * *} \\
(0.0078)\end{array}$ & $\begin{array}{r}-0.0181 * * \\
(0.0076)\end{array}$ & $\begin{array}{r}-0.0227 * * \\
(0.0086)\end{array}$ & $\begin{array}{r}-0.0287 * * * \\
(0.0072)\end{array}$ & $\begin{array}{r}-0.0350 * * * \\
(0.0074)\end{array}$ \\
\hline Tech X CNC Rank $\left(\beta_{2}\right)$ & $\begin{array}{r}0.0002 \\
(0.0012)\end{array}$ & $\begin{array}{r}0.0061^{* * *} \\
(0.0021)\end{array}$ & $\begin{array}{r}0.0070^{* * * *} \\
(0.0024)\end{array}$ & $\begin{array}{r}0.0062 * * \\
(0.0023)\end{array}$ & $\begin{array}{r}0.0216^{* * * *} \\
(0.0063)\end{array}$ & $\begin{array}{r}-0.0081^{* * *} \\
(0.0014)\end{array}$ & $\begin{array}{r}-0.0096 * * * \\
(0.0024)\end{array}$ & $\begin{array}{r}-0.0091^{* * *} \\
(0.0019)\end{array}$ & $\begin{array}{r}-0.0095^{* * *} \\
(0.0026)\end{array}$ \\
\hline $\begin{array}{l}\text { High-initial-wage X } \\
\text { CNC Rank }\left(\beta_{3}\right)\end{array}$ & $\begin{array}{r}0.0014 \\
(0.0016)\end{array}$ & $\begin{array}{l}-0.0118^{*} \\
(0.0059)\end{array}$ & $\begin{array}{r}-0.0086^{* *} \\
(0.0035)\end{array}$ & $\begin{array}{r}-0.0073^{* * *} \\
(0.0018)\end{array}$ & $\begin{array}{r}-0.0150 * * \\
(0.0057)\end{array}$ & $\begin{array}{r}-0.0314 * * * \\
(0.0074)\end{array}$ & $\begin{array}{r}-0.0322 * * * \\
(0.0096)\end{array}$ & $\begin{array}{r}-0.0431^{* * * *} \\
(0.0130)\end{array}$ & $\begin{array}{r}-0.0426 * * * \\
(0.0140)\end{array}$ \\
\hline $\begin{array}{l}\text { \# of observations } \\
\text { R-squared }\end{array}$ & $\begin{array}{r}12984300 \\
0.2108\end{array}$ & $\begin{array}{r}11971100 \\
0.1732\end{array}$ & $\begin{array}{r}11334900 \\
0.1817\end{array}$ & $\begin{array}{r}10861700 \\
0.1831\end{array}$ & $\begin{array}{r}6492100 \\
0.2112\end{array}$ & $\begin{array}{r}10904200 \\
0.6726\end{array}$ & $\begin{array}{r}5399500 \\
0.5764\end{array}$ & $\begin{array}{r}3145300 \\
0.5430\end{array}$ & $\begin{array}{r}1858400 \\
0.5238\end{array}$ \\
\hline $\begin{array}{l}\text { High vs Low Wage in } \\
\text { Tech industry }\left(\beta_{1}+\beta_{3}\right) \\
\text { p value }\end{array}$ & $\begin{array}{r}0.0100 * * * \\
6.46 \mathrm{e}-09\end{array}$ & $\begin{array}{r}0.0093 * * * \\
0.000197\end{array}$ & $\begin{array}{r}0.0097 * * * \\
0.00157\end{array}$ & $\begin{array}{r}0.00658 * * \\
0.0384\end{array}$ & $\begin{array}{r}0.0274 * * * \\
0.000151\end{array}$ & $\begin{array}{r}-0.0495 * * * \\
0.000925\end{array}$ & $\begin{array}{r}-0.0549 * * * \\
0.00289\end{array}$ & $\begin{array}{r}-0.0717 * * * \\
3.76 \mathrm{e}-06\end{array}$ & $\begin{array}{r}-0.0777 * * * \\
1.27 \mathrm{e}-07\end{array}$ \\
\hline $\begin{array}{l}\text { Tech vs Non-Tech in } \\
\text { High-initial-wage jobs } \\
\left(\beta_{1}+\beta_{2}\right) \\
\text { p value }\end{array}$ & $\begin{array}{r}0.0088 * * * \\
4.00 \mathrm{e}-06\end{array}$ & $\begin{array}{r}0.0271^{* * *} \\
0.000998\end{array}$ & $0.0253 * * *$ & $\begin{array}{r}0.0201^{* * * *} \\
5.00 \mathrm{e}-05\end{array}$ & $0.0640 * * *$ & $-0.0262 * * *$ & $-0.0323 * * *$ & $\begin{array}{r}-0.0377 * * * \\
0.000112\end{array}$ & $\begin{array}{r}-0.0446 * * * \\
1.16 \mathrm{e}-05\end{array}$ \\
\hline Fixed Effects & \multicolumn{9}{|c|}{ State + [Industry - Starting Year - Firm Size - Starting Wage - Starting Age - Sex] } \\
\hline Sample & All job & are not rig & nsored by & quarter & $\begin{array}{c}\text { Spell started } \\
2000 \text { or earlier }\end{array}$ & & ontinuing & in the qu & \\
\hline
\end{tabular}




\section{Table A9. Effect of CNC on Initial Wage}

This table reports the differential treatment effect of CNC enforceability on initial wage of job, corresponding to Table 2 and Table 4 . The dependent variables are the log of initial wage (i.e. second quarter wage) of each job. CNC Score is measured as the 2009 CNC enforcement index scores. The fixed effects dummy variables do not include the starting wage component for these results. All standard errors are clustered by state. ${ }^{* * *},{ }^{* *}$, and ${ }^{*}$ denote significance levels of $1 \%$, $5 \%$, and $10 \%$, respectively.

\begin{tabular}{|c|c|c|}
\hline $\begin{array}{l}\text { Dependent Variable: } \\
\text { Log of initial wage }\end{array}$ & $\begin{array}{c}(1) \\
\text { Corresponding Table: Table } 2 \\
\end{array}$ & \begin{tabular}{|c|}
$(2)$ \\
Corresponding Table: Table 4 \\
\end{tabular} \\
\hline Tech X High-initial-wage X CNC Score $\left(\beta_{1}\right)$ & & $\begin{array}{l}-0.0775 \\
(0.1200)\end{array}$ \\
\hline Tech X CNC Score $\left(\delta\right.$ or $\left.\beta_{2}\right)$ & $\begin{array}{r}-0.0259 * * * \\
(0.0019)\end{array}$ & $\begin{array}{r}-0.0235^{* * *} \\
(0.0033)\end{array}$ \\
\hline High-initial-wage X CNC Score $\left(\beta_{3}\right)$ & & $\begin{array}{r}-0.2399 \\
(0.2965)\end{array}$ \\
\hline \# of observations & 13205400 & 13205400 \\
\hline R-squared & 0.1853 & 0.1919 \\
\hline $\begin{array}{l}\text { High vs Low Wage in Tech industry }\left(\beta_{1}+\beta_{3}\right) \\
\text { p value }\end{array}$ & & $\begin{array}{l}-0.317 \\
0.0876\end{array}$ \\
\hline $\begin{array}{l}\text { Tech vs Non-Tech in High-initial-wage jobs }\left(\beta_{1}+\beta_{2}\right) \\
\text { p value }\end{array}$ & & $\begin{array}{r}-0.101 \\
0.396\end{array}$ \\
\hline Fixed Effects & \multicolumn{2}{|c|}{ State + [Industry - Starting Year - Firm Size - Starting Age - Sex] } \\
\hline Sample & \multicolumn{2}{|c|}{ All continuing jobs in the quarter } \\
\hline
\end{tabular}

